\title{
UPDATE ON THE USE OF QUADRIVALENT CONJUGATE MENINGOCOCCAL VACCINES
}

\section{Preamble}

The National Advisory Committee on Immunization (NACl) provides the Public Health Agency of Canada with ongoing and timely medical, scientific and public health advice relating to immunization. The Public Health Agency of Canada acknowledges that the advice and recommendations set out in this statement are based upon the best current available scientific knowledge and is disseminating this document for information purposes. People administering the vaccine should also be aware of the contents of the relevant product monograph(s). Recommendations for use and other information set out herein may differ from that set out in the product monograph(s) of the Canadian manufacturer(s) of the vaccine(s). Manufacturer(s) have sought approval of the vaccine(s) and provided evidence as to its safety and efficacy only when it is used in accordance with the product monographs. NACl members and liaison members conduct themselves within the context of the Public Health Agency of Canada's Policy on Conflict of Interest, including yearly declaration of potential conflict of interest.

Members: Dr. J. Langley (Chairperson), Dr. B. Warshawsky (Vice-Chairperson), Dr. S. Ismail (Executive Secretary), Dr. N. Crowcroft, Ms. A. Hanrahan, Dr. B. Henry, Dr. D. Kumar, Dr. S. McNeil, Dr. B. Seifert, Dr. C. Quach-Thanh, Dr. D. Skowronski, Dr. C. Cooper, Dr. W. Vaudry, Dr. R. Warrington

Liaison Representatives: Dr. B. Bell (Centers for Disease Control and Prevention, U.S.), Dr. J. Brophy (Canadian Association for Immunization Research and Evaluation), Dr. A. Mawle, (Centres for Disease Control and Prevention, U.S.), Dr. H. Morrison (Council of Chief Medical Officers of Health), Mme S. Pelletier (Community Hospital Infection Control Association), Ms. K. Pielak (Canadian Nursing Coalition for Immunization), Dr. P. Plourde (Committee to Advise on Tropical Medicine and Travel), Dr. S. Rechner (College of Family Physicians of Canada), Dr. M. Salvadori (Canadian Paediatric Society), Dr. V. Senikas (Society of Obstetricians and Gynaecologists of Canada), Dr. N. Sicard (Canadian Public Health Association), Dr. P. Van Buynder (Council of Chief Medical Officers of Health), Dr. P. Orr (Association of Medical Microbiology and Infectious Disease)

Ex-Officio Representatives: Ms. M. FarhangMehr (Centre for Immunization and Respiratory Infectious Diseases, Public Health Agency of Canada), Dr. S. Desai (Centre for Immunization and Respiratory Infectious Diseases, PHAC), Dr. B. Law (Centre for Immunization and Respiratory Infectious Diseases, PHAC), LCol (Dr.) J. Anderson (Department of National Defence), Dr. E. Farzad (First Nations and Inuit Health Branch, Health Canada), Dr. F. Hindieh (Biologics and Genetic Therapies Directorate, Health Canada), Dr. J. A. Laroche, (Centre for Immunization and Respiratory Infectious Diseases, PHAC), Dr. P. Varughese (Centre for Immunization and Respiratory Infectious Diseases, PHAC). Dr. J. Xiong, (Biologics and Genetic Therapies Directorate, Health Canada), Dr. R. Pless, (Centre for Immunization and Respiratory Infectious Diseases, PHAC)

†This statement was prepared by Dr. B. Warshawsky and approved by NACl.

NACl gratefully acknowledges the contributions of Dr. S. Desai, Dr. S. Deeks, Dr. P. De Wals, Dr. N. Crowcroft, Dr. S. Ismail, and Ms. J. Lourenco. 


\section{TABLE OF CONTENTS}

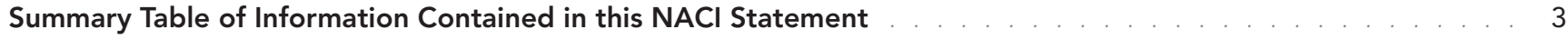

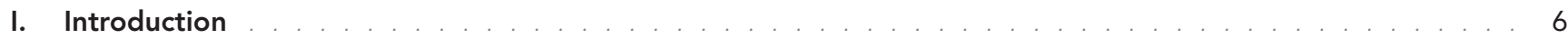

I.1 Overview of past National Advisory Committee Immunization (NACI)

recommendations for conjugate meningococcal vaccines . . . . . . . . . . . . . . . . . . . . . 6

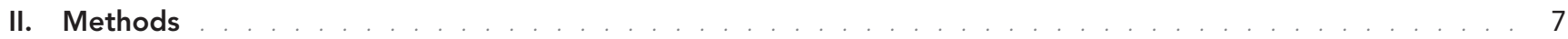

III. Epidemiology of invasive meningococcal disease in Canada . . . . . . . . . . . . . . . . . . . . . . . . . 7

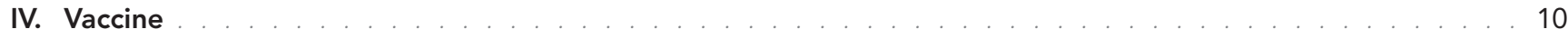

IV.1 Meningococcal conjugate immunization schedules used in Canada . . . . . . . . . . . . . . . 10

IV.2 Men-C-ACYW-135-CRM (Menveo ${ }^{\mathrm{TM}}$ ) description and composition . . . . . . . . . . . . . . . . . . . . .

IV.3 Efficacy and effectiveness of Men-C-ACYW-135-CRM (Menveo ${ }^{\text {TM }}$ ) and Men-C-ACYW-135-D (Menactra ${ }^{\mathrm{TM}}$ ) . . 12

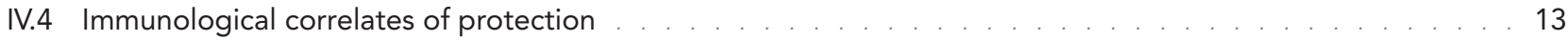

IV.5 Immunogenicity of Men-C-ACYW-135-CRM (Menveo $\left.{ }^{\mathrm{TM}}\right) \ldots \ldots \ldots$

IV.6 Schedule, dosage and route of administration for Men-C-ACYW-135-CRM (Menveo ${ }^{\text {TM}}$ ) . . . . . . . . . 19

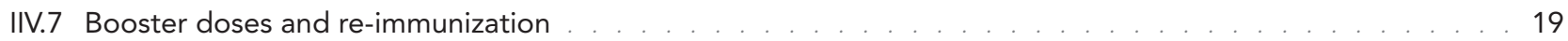

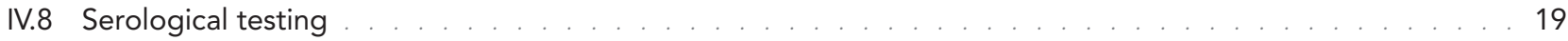

IV.9 Storage requirements for Men-C-ACYW-135-CRM (Menveo $\left.{ }^{\mathrm{TM}}\right) \quad \ldots \ldots$

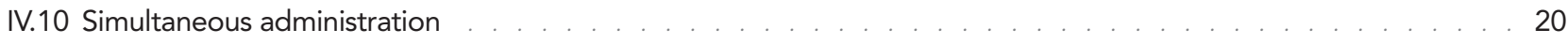

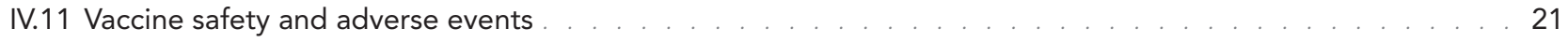

IV.12 Contraindications and precautions for Men-C-ACYW-135-CRM (Menveo ${ }^{\mathrm{TM}}$ ) . . . . . . . . . . . . . 22

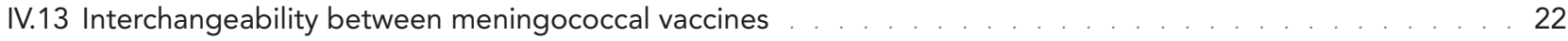

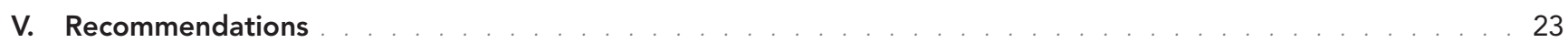

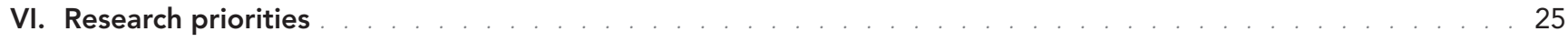

VII. Surveillance priorities . . . . . . . . . . . . . . . . . . . . . . . . . . . . . . . . . 26

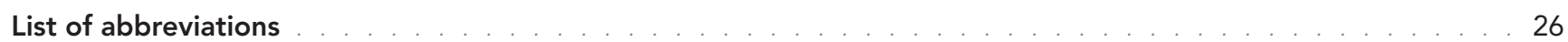

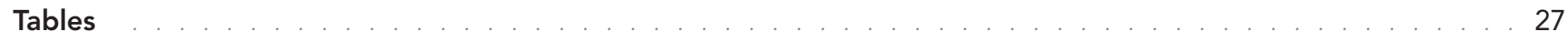

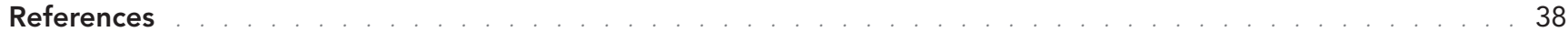




\title{
Summary Table of Information Contained in this NACI Statement
}

\section{The following table highlights key information for immunization providers. Please refer to the remainder of the statement for details.}

\author{
TABLE 1: Summary of information contained in this NACI Statement
}

1. What

\section{What is meningococcal disease?}

Meningococcal disease usually presents as an acute febrile illness with rapid onset and features of meningitis or septicemia (meningococcemia), or both, and a characteristic non-blanching rash. Overall mortality is approximately $10 \%$, and $10-20 \%$ of survivors have long term sequelae which include hearing loss, neurologic disabilities, and digit or limb amputations. In 2007, 229 cases of meningococcal disease were reported in Canada, the majority (131 cases) was serogroup B, for which the highest rates occur in infants. There is currently no vaccine against serogroup B disease in Canada. Rates of serogroup C meningococcal disease have decreased due to vaccination programs, and in 2007, the number of serogroup $Y$ cases slightly exceeded the number of serogroup $C$ cases ( 30 serogroup $C$ cases and 35 serogroup $Y$ cases). The median age for serogroup $Y$ disease (46 years) is older than for serogroups $C$ and W135. Very little serogroup $A$ disease occurs in Canada.

\section{What are meningococcal conjugate vaccines?}

Monovalent meningococcal C conjugate vaccines have been available in Canada since 2001. A quadrivalent (serogroups A, C, Y and W135) meningococcal vaccine conjugated to diphtheria toxoid (Menactra ${ }^{\mathrm{TM}}$ - sanofi pasteur) was authorized for use in 2006 for individuals 2 to 55 years of age. A second quadrivalent conjugate meningococcal vaccine (Menveo ${ }^{\mathrm{TM}}$ - Novartis Vaccines Inc.) was authorized for use in May 2010 for individuals 11-55 years of age and in June 2011 the authorization was extended to include 2-10 year olds. Menveo ${ }^{\mathrm{TM}}$ contains serogroups A $(10 \mu \mathrm{g}), \mathrm{C}(5 \mu \mathrm{g}), \mathrm{W} 135(5 \mu \mathrm{g})$ and $\mathrm{Y}(5 \mu \mathrm{g})$, with each serogroup individually conjugated to $\mathrm{CRM}_{197}$, a variant protein of diphtheria toxin, which serves as a carrier protein. This statement provides information regarding the immunogenicity, safety and recommended uses of this new vaccine. The statement also provides updated effectiveness and safety information about Menactra ${ }^{\mathrm{TM}}$ and information about its simultaneous use with other adolescent vaccines.

\section{Who}

\section{Who is immunized?}

Menveo $^{\mathrm{TM}}$ is authorized for use in people $2-55$ years of age. Its use may also be considered in individuals $\geq 56$ years of age. Immunogenicity and safety data indicate that Menveo ${ }^{\mathrm{TM}}$ may be used in infants as young as 2 months of age although it is not currently authorized for use in this age group.

This $\mathrm{NACl}$ statement recommends the use of conjugate meningococcal vaccines as follows:

\section{Adolescents:}

- In addition to routine meningococcal $\mathrm{C}$ conjugate vaccine for infants and/or young children, $\mathrm{NACl}$ recommends a routine conjugate meningococcal vaccination for adolescents at around 12 years of age. If a quadrivalent conjugate product is chosen for this adolescent dose, either Menactra ${ }^{\mathrm{TM}}$ or Menveo ${ }^{\mathrm{TM}}$ may be used. (NACl Recommendation Grade B).

\section{High-Risk Individuals:}

- $\mathrm{NACl}$ recommends a conjugate quadrivalent meningococcal vaccine for high risk individuals. (NACl Recommendation Grade B):

- Persons with anatomic or functional asplenia (including sickle cell disease);

- Persons who have complement, properdin, factor D or primary antibody deficiencies;

- Persons with acquired complement deficiency (eg. those receiving eculizumab (Soliris ${ }^{\mathrm{TM}}$ );

- Travellers when meningococcal vaccine is recommended (meningitis belt of Subsaharan Africa) or required (pilgrims to the Hajj in Mecca);

- Research, industrial and clinical laboratory personnel who are routinely exposed to N. meningitidis; and

- Military personnel during recruit training and on certain deployments $\mathrm{NACl}$ also suggests consideration of a quadrivalent conjugate meningococcal vaccine for individuals with HIV.

- For high risk individuals 2 years of age and older, use either Menactra ${ }^{\mathrm{TM}}$ or Menveo ${ }^{\mathrm{TM}}$ (NACl Recommendation Grade B). Two doses at least 8 weeks apart are recommended for those in the above high risk group due to underlying medical conditions (asplenia; complement, properdin, factor D or primary antibody deficiencies; or HIV). For those at ongoing risk due to underlying medical conditions or exposure, booster doses are recommended as outlined in this statement.

- For high risk individuals less than 2 years of age, based on available published data, the quadrivalent conjugate meningococcal vaccine that should be used is Menveo ${ }^{\mathrm{TM}}$ (NACl Recommendation Grade B). Possible schedules are provided in this statement. 
- For those who only receive one dose of quadrivalent meningococcal vaccine (e.g. Travellers) and who are 2 to 10 years of age, routine monovalent meningococcal $\mathrm{C}$ conjugate vaccine should already have been administered and if not previously given, should also be administered at least one month after the quadrivalent conjugate vaccine.

\section{Close contacts and outbreaks:}

- Serogroup C:

- For those 11 years of age and older, use either a monovalent conjugate $C$ vaccine or one of the available quadrivalent conjugate meningococcal vaccines.

- For those less than 11 years of age, use a monovalent meningococcal C conjugate product (NACl Recommendation Grade A).

- Serogroups A, W135, and Y:

- Use a quadrivalent conjugate meningococcal vaccine.

- For those 2 years of age and older, use either Menactra ${ }^{\mathrm{TM}}$ or Menveo ${ }^{\mathrm{TM}}$ (NACl Recommendation Grade A).

- For children less than 2 years of age, use only Menveo ${ }^{\mathrm{TM}}$ (NACl Recommendation Grade B). Possible schedules for infants and young children are provided in this statement.

For those previously vaccinated who are now close contacts or during outbreaks, revaccination as follows is recommended, based on expert opinion:

- Those previously vaccinated with a serogroup that differs from the index case or outbreak strain should be vaccinated immediately with the appropriate vaccine (as outlined above);

- Those previously vaccinated with a serogroup that is the same as the index case or outbreak strain should be revaccinated with the appropriate vaccine(as outlined above):

- If they were less than 1 year of age at last meningococcal vaccination and more than 4 weeks have passed since their last meningococcal vaccine;

- If they have an underlying medical condition that puts them at risk for meningococcal disease and more than 4 weeks have passed since their last meningococcal vaccine;

- If more than a year has passed since their last meningococcal vaccine if they were not less than 1 year of age at the time of their last meningococcal vaccination and if they have no underlying medical condition that puts them at risk for meningococcal disease.

\section{How}

\section{Administration of Menveo ${ }^{\mathrm{TM}}$}

- For those 2-55 years of age, Menveo ${ }^{\mathrm{TM}}$ is given as $0.5 \mathrm{ml} \mathrm{IM}$ dose.

- The product is reconstituted by mixing the liquid (containing serogroups C, W135, and Y) with the lyophylized powder (containing serogroup A). The reconstituted product should be used immediately, but may be held at or below $25^{\circ} \mathrm{C}$ for up to 2 hours.

\section{Menveo ${ }^{\mathrm{TM}}$ contraindications:}

A history of anaphylaxis to a previous dose of meningococcal vaccine, to any vaccine that contains diphtheria toxoid or $\mathrm{CRM}_{197}$, or to any other component of Menveo ${ }^{\mathrm{TM}}$.

\section{Menveo ${ }^{\mathrm{TM}}$ precautions:}

Menveo ${ }^{\mathrm{TM}}$ has not been studied in pregnancy; its use may be considered when the benefits outweigh the risks. A past history of GBS is not considered a need for caution when administering Menactra ${ }^{\mathrm{TM}}$ or Menveo ${ }^{\mathrm{TM}}$. An acute febrile illness which is severe warrants deferral until symptoms resolve.

\section{Co-administration with other vaccines:}

Menactra ${ }^{\mathrm{TM}}$ or Menveo ${ }^{\mathrm{TM}}$ may be given concomitantly with other age appropriate adolescent and adult vaccines. A lower antibody response to pertussis antigens was noted when Tdap was co-administered with Menveo ${ }^{\mathrm{TM}}$; the highest immunological response to pertussis antigens was achieved when Tdap was given one month after Menveo ${ }^{\mathrm{TM}}$. Menveo ${ }^{\mathrm{TM}}$ has been studied with many routine paediatric vaccines and no immunological interference has been observed. Menveo ${ }^{\mathrm{TM}}$ co-administration with the 13 -valent conjugate pneumococcal vaccine requires further study. 


\section{Re-vaccination:}

For high risk individuals who remain at ongoing or recurring risk of exposure to meningococcal disease (research, industrial and clinical laboratory personnel who are potentially routinely exposed to N. meningitidis; or traveller who remain in or revisit areas where meningococcal vaccine is recommended); or high risk individuals with underlying medical conditions (asplenia; complement, properdin, factor D or primary antibody deficiencies; or HIV), the following re-vaccination schedule is recommended by $\mathrm{NACl}$, based on expert opinion:

- For those vaccinated at 6 years of age and under: provide a booster dose 3-5 years after the last dose, followed by every 5 years.

- For those vaccinated at 7 years of age and older: provide a booster dose 5 years after the last dose, followed by every 5 years.

- Travellers to Hajj should check recommendations for re-vaccination at: http://www.hajinformation.com/main/p3001.htm as more frequent re-vaccination may be required.

A quadrivalent conjugate meningococcal vaccine should be used for re-vaccination of the above groups and based on expert opinion, either Men-C-ACYW-135- D (Menactra ${ }^{\mathrm{TM}}$ ) or Men-C-ACYW-135-CRM (Menveo ${ }^{\mathrm{TM}}$ ) can be used, regardless of what meningococcal vaccine was used for the initial vaccination.

See above for revaccination of close contacts or during outbreaks.

\section{Why}

"Counseling Points" for providers to emphasize with clients when discussing these recommendations

IMD mortality is approximately $10 \%$. Of IMD survivors, $10 \%$ to $20 \%$ have long term sequelae which include hearing loss, neurologic disabilities, and digit or limb amputations. Therefore, immunization against vaccine preventable IMD serogroups is important for those at higher risk.

- Menactra ${ }^{\mathrm{TM}}$ and Menveo ${ }^{\mathrm{TM}}$ are currently authorized for use in those 2-55 years of age. They have been shown to be immunogenic in clinical trials for individuals 2-55 years of age, with one study of Menveo ${ }^{\mathrm{TM}}$ extending to 65 years of age.

- Immunogenicity studies suggest that Menveo ${ }^{\mathrm{TM}}$ induces a good response in young children and infants, with several schedules being assessed.

- Both Menactra ${ }^{\mathrm{TM}}$ and Menveo ${ }^{\mathrm{TM}}$ have been studied with several age-appropriate vaccines given at the same time.

A study in the US among those primarily 11 to 18 years of age indicates that Menactra ${ }^{\mathrm{TM}}$ has an effectiveness of approximately $80-85 \%$ within 3 to 4 years of administration. Preliminary results from a case control study of Menactra ${ }^{\mathrm{TM}}$ found it to be approximately $78 \%$ effective, with effectiveness decreasing over time up to 5 years after administration. There is currently no effectiveness data for Menveo ${ }^{\mathrm{TM}}$ but post-licensure data may become available in the future.

No significant safety concerns were found with regard to Menactra ${ }^{\mathrm{TM}}$ and Menveo ${ }^{\mathrm{TM}}$ in clinical trials. Two recent studies in the United States have not found any association between Menactra ${ }^{\mathrm{TM}}$ and Guillain-Barré Syndrome. 


\section{Introduction}

This statement will supplement previous conjugate meningococcal vaccine statements ${ }^{(1)-(5)}$ which have outlined the use of monovalent meningococcal $\mathrm{C}$ conjugate vaccines and the only previously available quadrivalent conjugate meningococcal vaccine, Men-C-ACYW-135-D (Menactra ${ }^{\mathrm{TM}}$ ). This statement provides information and recommendations for use of a second quadrivalent conjugate vaccine against meningococcal disease, Men-C-ACYW-135-CRM (Menveo ${ }^{\mathrm{TM}}$ ) produced by Novartis Vaccines Inc. which was authorized for use in Canada in May 2010 for individuals aged 11 to 55 years, and extended to include 2-10 year olds in June 2011.

This statement will:

- Review existing National Advisory Committee on Immunization (NACl) recommendations on the use of conjugate meningococcal vaccines;

- Update the epidemiology of meningococcal disease in Canada by providing data to 2007, which includes one additional year of data compared to the previous $\mathrm{NACl}$ statement ${ }^{(5)}$;

- Provide an update on the available conjugate meningococcal vaccines and the vaccination schedules used in Canada;

- Describe indicators of immunogenicity for invasive meningococcal disease (IMD);

- Provide information and recommendations for use of the newly authorized quadrivalent conjugate meningococcal vaccine, Men-C-ACYW-135-CRM (Menveo ${ }^{\mathrm{TM}}$ );

- Provide updated safety information and information regarding the concomitant use of Men-C-ACYW-135-D (Menactra ${ }^{\mathrm{TM}}$ ) with other vaccines;

- Recommend two or more doses of quadrivalent meningococcal vaccine, dependent on age, for those at high risk for meningococcal disease due to underlying medical conditions; and

- Recommend re-vaccination with a quadrivalent conjugate meningococcal vaccine for people at ongoing risk due to underlying medical conditions, potential ongoing or recurring exposure, or who are close contacts of a case of IMD or during an outbreak.

\section{I.1 OVERVIEW OF PAST NATIONAL ADVISORY COMMITTEE IMMUNIZATION (NACI) RECOMMENDATIONS FOR CONJUGATE MENINGOCOCCAL VACCINES}

Since 2001, NACl has recommended the use of a meningococcal $\mathrm{C}$ conjugate vaccine for infants (i.e., children $<1$ year of age), children from 1-4 years of age, adolescents and young adults. $\mathrm{NACl}$ recommended the vaccine be considered for children $\geq 5$ years of age who have not yet reached adolescence. Meningococcal $C$ conjugate vaccine was also recommended for close contacts of cases of invasive meningococcal disease (IMD) caused by serogroup C Neisseria meningitidis and to control outbreaks of serogroup C IMD. It could be considered, in addition to unconjugated polysaccharide quadrivalent vaccine, for others at high risk for meningococcal disease. (1)

In May 2007, NACl recommended the use of quadrivalent conjugate meningococcal vaccine for serogroups A, C, W135 and $\mathrm{Y}$ (Men-C-ACYW-135-D Menactra ${ }^{\mathrm{TM}}$ - sanofi pasteur) for immunization of persons 2-55 years of age in the following high-risk groups:

- Persons with anatomic or functional asplenia;

- Persons who have complement, properdin, or factor D deficiencies;

- Travellers when meningococcal vaccine is indicated or required, including pilgrims to the Hajj in Mecca;

- Research, industrial and clinical laboratory personnel who are routinely exposed to $N$. meningitidis; and

- Military recruits.

In addition, the vaccine was recommended for close contacts of persons with IMD caused by serogroups A, W135, or $\mathrm{Y}$ and for the control of outbreaks caused by these serogroups. The monovalent meningococcal $\mathrm{C}$ conjugate vaccine was recommended for close contacts of cases of serogroup C IMD and to control outbreaks caused by serogroup C IMD. $\mathrm{NACl}$ also stated that the quadrivalent conjugate meningococcal vaccine could be considered for high-risk individuals, as defined above, who are $\geq 56$ years of age and also for individuals with HIV. For routine immunization of adolescents 11-24 years of age, $\mathrm{NACl}$ recommended use of a meningococcal $\mathrm{C}$ conjugate vaccine unless local epidemiology warranted the use of the quadrivalent conjugate meningococcal vaccine. ${ }^{(3)}$ 
In November 2007, $\mathrm{NACl}$ recommended that if meningococcal C conjugate vaccine is given to infants $<12$ months of age, a booster dose should be given in the second year of life (from 12 to 23 months of age). This replaced NACl's previous recommendation for infants that stated that one dose of a primary infant immunization series of meningococcal $\mathrm{C}$ conjugate vaccine be given after 5 months of age. ${ }^{(4)}$

In its statement published in April 2009, NACl recommended the addition of a routine adolescent dose of conjugate meningococcal vaccine, optimally at 12 years of age. ${ }^{(5)}$ This dose was in addition to any infant or toddler meningococcal

\section{Methods}

$\mathrm{NACl}$ reviewed the burden of illness of meningococcal disease by serogroup and the safety and immunogenicity of the newly authorized Men-C-ACYW-135-CRM (Menveo ${ }^{\mathrm{TM}}$ ) vaccine, vaccine schedules in Canada, and other aspects of the overall immunization strategy. The knowledge synthesis was performed by the Meningococcal Working Group. Following critical appraisal of individual studies, a summary table (Table 8) with ratings of the quality of the evidence using NACl's methodological hierarchy (outlined in Table 9, 10 and 11) was prepared, and proposed recommendations for vaccine conjugate vaccinations. The choice of vaccine could be either a monovalent meningococcal $\mathrm{C}$ conjugate vaccine or the quadrivalent conjugate meningococcal vaccine. It was recommended that the choice of product be determined by provinces / territories based on their burden of illness from serogroups A, Y and W135, cost and other programmatic considerations. The April 2009 statement also expanded the list of individuals considered at high risk for IMD by recommending that persons with primary antibody deficiencies receive the quadrivalent conjugate meningococcal vaccine.

use developed. The Working Group Chair presented the evidence and proposed recommendations to $\mathrm{NACl}$ on February 2 and June 2, 2010. Following thorough review of the evidence and consultation, $\mathrm{NACl}$ voted on specific recommendations. The description of relevant considerations, rationale for specific decisions, and knowledge gaps are described in the text. The Public Health Agency of Canada (PHAC) maintains documentation of these processes throughout knowledge synthesis and recommendation development.

\section{Epidemiology of invasive meningococcal disease in Canada}

Epidemiological data for the burden of invasive meningococcal disease (IMD) in Canada has previously been reviewed. ${ }^{(5)}$ One additional year of data, 2007, has been included in the figure and tables provided below which summarize Canadian epidemiological data on IMD.

Figure 1 shows IMD trends over the past ten years (1998-2007). The introduction of paediatric meningococcal $\mathrm{C}$ programs beginning in 2001 in Canada appears to have been associated with a decline in the incidence of IMD caused by serogroup C.(6)-(8) In contrast, there have been steady rates of IMD caused by serogroups A, Y, W-135, with some year to year fluctuation. From 2004 to 2007 there has been a progressive increase in rates of serogroup B IMD. Since the decline in serogroup C cases, serogroup $B$ has become the most common IMD serogroup to affect Canadians. Currently there is no vaccine available in Canada to prevent serogroup B disease.

Table 2 provides data, by serogroup, indicating the number and rates of IMD cases for 2007 as well as 10 year averages; the 10 year average median ages and case fatality rates by serogroup are also outlined. The numbers of cases of serogroup C IMD have fallen to their lowest level in the past 10 years such that in 2007, reported cases of serogroup $Y$ disease slightly exceeded cases of serogroup C disease.

Table 3 provides information on the number and rates of IMD cases by serogroup for all provinces and territories in 2007. Table 4 provides similar data averaged over the 10-year period from 1998 to 2007. These tables indicate that Quebec has notably higher rates of serogroup $B$ disease compared to other provinces and territories.

Table 5 provides numbers and rates of IMD cases by age group and serogroup for 2007. The incidence of IMD is highest in infants less than one year of age with an incidence rate of 6.94 per 100000 in 2007, the majority of which is due to serogroup $B$ disease. The tendency for serogroup $Y$ to occur at older ages is also evident in Table 5. 
FIGURE 1: Incidence rates of invasive meningococcal disease by serogroup and year, 1998-2007.(9)

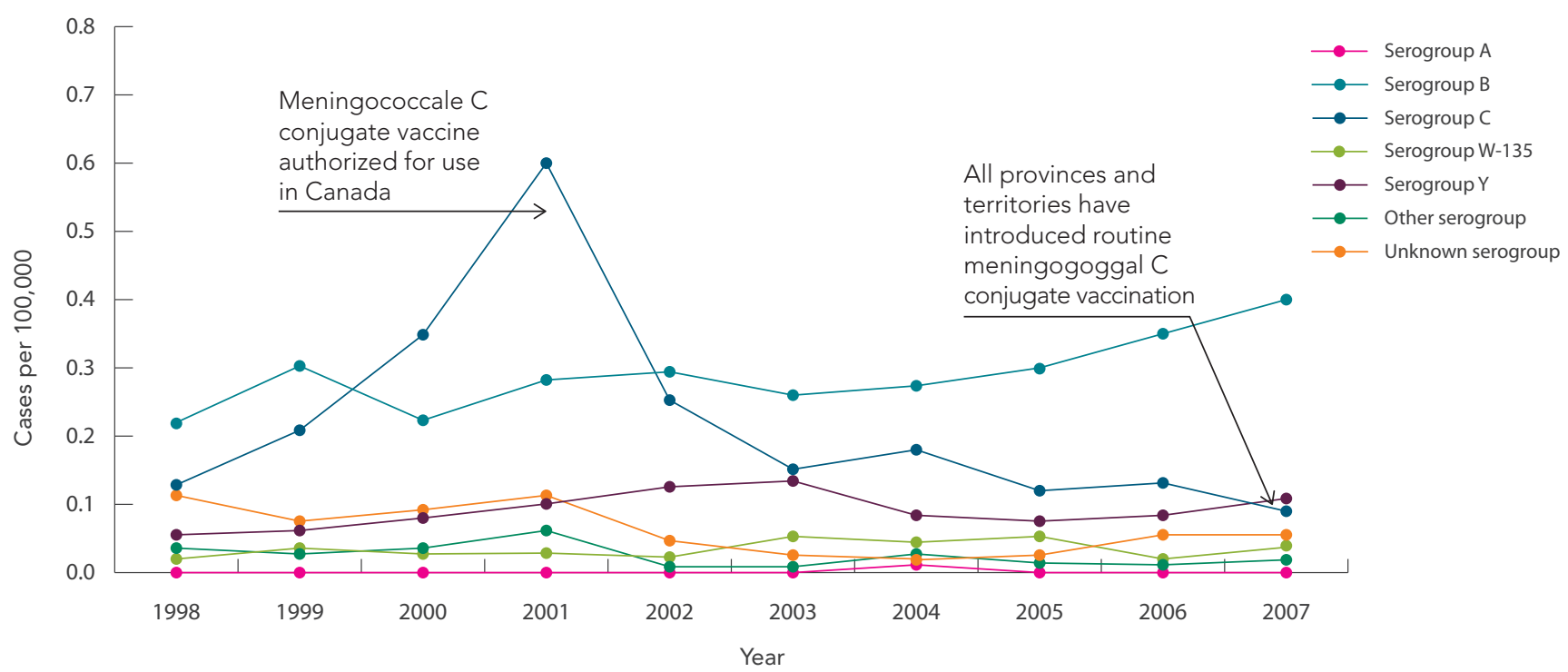

TABLE 2: Summary of epidemiology of invasive meningococcal disease in Canada in 2007 and between 1998 and 2007 by serogroup. ${ }^{(9)}$

\begin{tabular}{|c|c|c|c|c|c|c|}
\hline \multirow[t]{2}{*}{ Serogroup } & \multicolumn{2}{|r|}{2007} & \multicolumn{4}{|c|}{ 1998-2007 } \\
\hline & $\begin{array}{l}\text { Number } \\
\text { of cases }\end{array}$ & $\begin{array}{l}\text { Incidence (IMD } \\
\text { cases } / 100000 \\
\text { population) }\end{array}$ & $\begin{array}{l}\text { Average annual } \\
\text { number of } \\
\text { cases (range) }\end{array}$ & $\begin{array}{l}\text { Average annual } \\
\text { incidence } \\
\text { (IMD cases } / 100000 \\
\text { population) }\end{array}$ & $\begin{array}{l}\text { Median age } \\
\text { in years }\end{array}$ & $\begin{array}{l}\text { Case fatality } \\
\text { rate* }^{*}\end{array}$ \\
\hline A & 0 & 0.00 & $0.4(0-3)$ & 0.00 & 62 & 0.00 \\
\hline B & 131 & 0.40 & 91.5 (65-131) & 0.29 & 16 & 5.36 \\
\hline C & 30 & 0.09 & $68.9(30-182)$ & 0.22 & 20 & 13.79 \\
\hline $\mathbf{Y}$ & 35 & 0.11 & $28.2(17-41)$ & 0.09 & 46 & 5.65 \\
\hline W135 & 13 & 0.04 & $10.6(5-17)$ & 0.03 & 23 & 8.49 \\
\hline
\end{tabular}

* Please note that the percentage of cases with missing outcome information for serogroups A, B, C, Y, and W- 135 were $20 \%, 49 \%, 42 \%, 56 \%$, and $57 \%$ respectively. Also note that in 2007, there were 4 cases of other serogroups and 16 cases where the serogroup was unknown. 
TABLE 3: Invasive meningococcal disease incidence per 100,000 population and number of cases, by serogroup and province/territory, $2007^{(9)}$

\begin{tabular}{|c|c|c|c|c|c|c|c|c|c|c|c|c|c|c|}
\hline $\begin{array}{l}\text { Province/ } \\
\text { Territory }\end{array}$ & $\mathrm{BC}$ & $A B$ & SK & MB & ON & $\mathrm{QC}$ & NB & NS & PE & NL & YK & NT & NU & Total \\
\hline $\begin{array}{l}\text { Incidence } \\
\text { (Number } \\
\text { of cases) }\end{array}$ & $\begin{array}{l}0.70 \\
(30)\end{array}$ & $\begin{array}{l}0.54 \\
(19)\end{array}$ & $\begin{array}{c}0.70 \\
(7)\end{array}$ & $\begin{array}{c}0.34 \\
(4)\end{array}$ & $\begin{array}{l}0.48 \\
(62)\end{array}$ & $\begin{array}{l}1.18 \\
(91)\end{array}$ & $\begin{array}{l}0.54 \\
(4)\end{array}$ & $\begin{array}{c}0.43 \\
(4)\end{array}$ & $\begin{array}{c}0.72 \\
(1)\end{array}$ & $\begin{array}{c}1.38 \\
(7)\end{array}$ & $\begin{array}{c}0 \\
(0)\end{array}$ & $\begin{array}{c}0 \\
(0)\end{array}$ & $\begin{array}{c}0 \\
(0)\end{array}$ & $\begin{array}{l}0.70 \\
(229)\end{array}$ \\
\hline Serogroup A & $\begin{array}{c}0 \\
(0)\end{array}$ & $\begin{array}{c}0 \\
(0)\end{array}$ & $\begin{array}{c}0 \\
(0)\end{array}$ & $\begin{array}{c}0 \\
(0)\end{array}$ & $\begin{array}{c}0 \\
(0)\end{array}$ & $\begin{array}{c}0 \\
(0)\end{array}$ & $\begin{array}{c}0 \\
(0)\end{array}$ & $\begin{array}{c}0 \\
(0)\end{array}$ & $\begin{array}{c}0 \\
(0)\end{array}$ & $\begin{array}{c}0 \\
(0)\end{array}$ & $\begin{array}{c}0 \\
(0)\end{array}$ & $\begin{array}{c}0 \\
(0)\end{array}$ & $\begin{array}{c}0 \\
(0)\end{array}$ & $\begin{array}{l}0 \\
(0)\end{array}$ \\
\hline Serogroup B & $\begin{array}{l}0.26 \\
(11)\end{array}$ & $\begin{array}{l}0.31 \\
(11)\end{array}$ & $\begin{array}{l}0.50 \\
(5)\end{array}$ & $\begin{array}{c}0.08 \\
(1)\end{array}$ & $\begin{array}{l}0.23 \\
(30)\end{array}$ & $\begin{array}{l}0.86 \\
(66)\end{array}$ & $\begin{array}{l}0.13 \\
(1)\end{array}$ & $\begin{array}{c}0.32 \\
(3)\end{array}$ & $\begin{array}{c}0 \\
(0)\end{array}$ & $\begin{array}{l}0.59 \\
(3)\end{array}$ & $\begin{array}{c}0 \\
(0)\end{array}$ & $\begin{array}{l}0 \\
(0)\end{array}$ & $\begin{array}{c}0 \\
(0)\end{array}$ & $\begin{array}{l}0.40 \\
(131)\end{array}$ \\
\hline Serogroup C & $\begin{array}{c}0.16 \\
(7)\end{array}$ & $\begin{array}{c}0 \\
(0)\end{array}$ & $\begin{array}{c}0 \\
(0)\end{array}$ & $\begin{array}{c}0 \\
(0)\end{array}$ & $\begin{array}{l}0.09 \\
(11)\end{array}$ & $\begin{array}{c}0.12 \\
(9)\end{array}$ & $\begin{array}{l}0.27 \\
(2)\end{array}$ & $\begin{array}{c}0 \\
(0)\end{array}$ & $\begin{array}{c}0 \\
(0)\end{array}$ & $\begin{array}{l}0.20 \\
(1)\end{array}$ & $\begin{array}{c}0 \\
(0)\end{array}$ & $\begin{array}{c}0 \\
(0)\end{array}$ & $\begin{array}{c}0 \\
(0)\end{array}$ & $\begin{array}{l}0.9 \\
(30)\end{array}$ \\
\hline Serogroup $Y$ & $\begin{array}{c}0.19 \\
(8)\end{array}$ & $\begin{array}{l}0.09 \\
(3)\end{array}$ & $\begin{array}{l}0.2 \\
(2)\end{array}$ & $\begin{array}{c}0.17 \\
(2)\end{array}$ & $\begin{array}{l}0.12 \\
(15)\end{array}$ & $\begin{array}{c}0.07 \\
(5)\end{array}$ & $\begin{array}{c}0 \\
(0)\end{array}$ & $\begin{array}{c}0 \\
(0)\end{array}$ & $\begin{array}{c}0 \\
\text { (0) }\end{array}$ & $\begin{array}{c}0 \\
(0)\end{array}$ & $\begin{array}{c}0 \\
(0)\end{array}$ & $\begin{array}{c}0 \\
(0)\end{array}$ & $\begin{array}{c}0 \\
(0)\end{array}$ & $\begin{array}{l}0.11 \\
(35)\end{array}$ \\
\hline $\begin{array}{l}\text { Serogroup } \\
W-135\end{array}$ & $\begin{array}{c}0.05 \\
(2)\end{array}$ & $\begin{array}{l}0.06 \\
(2)\end{array}$ & $\begin{array}{c}0 \\
(0)\end{array}$ & $\begin{array}{c}0.08 \\
(1)\end{array}$ & $\begin{array}{c}0.02 \\
(3)\end{array}$ & $\begin{array}{c}0.07 \\
(5)\end{array}$ & $\begin{array}{c}0 \\
(0)\end{array}$ & $\begin{array}{c}0 \\
(0)\end{array}$ & $\begin{array}{c}0 \\
(0)\end{array}$ & $\begin{array}{c}0 \\
(0)\end{array}$ & $\begin{array}{c}0 \\
(0)\end{array}$ & $\begin{array}{c}0 \\
(0)\end{array}$ & $\begin{array}{c}0 \\
(0)\end{array}$ & $\begin{array}{l}0.04 \\
(13)\end{array}$ \\
\hline $\begin{array}{l}\text { Other } \\
\text { Serogroups }\end{array}$ & $\begin{array}{c}0 \\
(0)\end{array}$ & $\begin{array}{l}0.06 \\
(2)\end{array}$ & $\begin{array}{c}0 \\
(0)\end{array}$ & $\begin{array}{c}0 \\
(0)\end{array}$ & $\begin{array}{c}0.01 \\
(1)\end{array}$ & $\begin{array}{c}0.01 \\
(1)\end{array}$ & $\begin{array}{c}0 \\
(0)\end{array}$ & $\begin{array}{c}0 \\
(0)\end{array}$ & $\begin{array}{c}0 \\
(0)\end{array}$ & $\begin{array}{c}0 \\
(0)\end{array}$ & $\begin{array}{c}0 \\
(0)\end{array}$ & $\begin{array}{c}0 \\
(0)\end{array}$ & $\begin{array}{c}0 \\
(0)\end{array}$ & $\begin{array}{c}0.01 \\
(4)\end{array}$ \\
\hline $\begin{array}{l}\text { Unknown } \\
\text { Serogroup }\end{array}$ & $\begin{array}{c}0.05 \\
(2)\end{array}$ & $\begin{array}{l}0.03 \\
(1)\end{array}$ & $\begin{array}{c}0 \\
(0)\end{array}$ & $\begin{array}{c}0 \\
(0)\end{array}$ & $\begin{array}{c}0.02 \\
(2)\end{array}$ & $\begin{array}{c}0.05 \\
(5)\end{array}$ & $\begin{array}{l}0.13 \\
(1)\end{array}$ & $\begin{array}{c}0.11 \\
(1)\end{array}$ & $\begin{array}{l}0.72 \\
(1)\end{array}$ & $\begin{array}{l}0.59 \\
(3)\end{array}$ & $\begin{array}{c}0 \\
(0)\end{array}$ & $\begin{array}{c}0 \\
(0)\end{array}$ & $\begin{array}{c}0 \\
(0)\end{array}$ & $\begin{array}{l}0.04 \\
(16)\end{array}$ \\
\hline
\end{tabular}

TABLE 4: Average annual invasive meningococcal disease incidence per 100,000 population and number of cases, by serogroup and province/territory, 1998-2007(9)

\begin{tabular}{|c|c|c|c|c|c|c|c|c|c|c|c|c|c|c|}
\hline $\begin{array}{l}\text { Province/ } \\
\text { Territory }\end{array}$ & $B C$ & $A B$ & SK & MB & ON & QC & NB & NS & PE & NL & YK & NT & NU & Canada \\
\hline $\begin{array}{l}\text { Average incidence } \\
\text { (Average number } \\
\text { of cases) }\end{array}$ & $\begin{array}{c}0.76 \\
(31.1)\end{array}$ & $\begin{array}{c}0.95 \\
(29.5)\end{array}$ & $\begin{array}{l}0.42 \\
(4.2)\end{array}$ & $\begin{array}{l}0.67 \\
(7.8)\end{array}$ & $\begin{array}{l}0.57 \\
(68)\end{array}$ & $\begin{array}{c}0.90 \\
(67.5)\end{array}$ & $\begin{array}{l}0.73 \\
(5.5)\end{array}$ & $\begin{array}{l}0.49 \\
(4.6)\end{array}$ & $\begin{array}{l}0.29 \\
(0.4)\end{array}$ & $\begin{array}{l}0.92 \\
(4.8)\end{array}$ & $\begin{array}{l}0.32 \\
(0.1)\end{array}$ & $\begin{array}{l}1.17 \\
(0.5)\end{array}$ & $\begin{array}{l}1.36 \\
(0.4)\end{array}$ & $\begin{array}{c}0.71 \\
(224.4)\end{array}$ \\
\hline Serogroup A & $\begin{array}{l}0.01 \\
(0.2)\end{array}$ & $\begin{array}{c}0.00 \\
(0)\end{array}$ & $\begin{array}{l}0.00 \\
(0)\end{array}$ & $\begin{array}{l}0.00 \\
(0)\end{array}$ & $\begin{array}{c}0.002 \\
(0.2)\end{array}$ & $\begin{array}{c}0.001 \\
(0.1)\end{array}$ & $\begin{array}{c}0.00 \\
(0)\end{array}$ & $\begin{array}{c}0.00 \\
(0)\end{array}$ & $\begin{array}{c}0.00 \\
(0)\end{array}$ & $\begin{array}{c}0.00 \\
(0)\end{array}$ & $\begin{array}{c}0.00 \\
(0)\end{array}$ & $\begin{array}{c}0.00 \\
(0)\end{array}$ & $\begin{array}{c}0.00 \\
(0)\end{array}$ & $\begin{array}{c}0.002 \\
(0.5)\end{array}$ \\
\hline Serogroup B & $\begin{array}{c}0.25 \\
(10.4)\end{array}$ & $\begin{array}{c}0.22 \\
(7)\end{array}$ & $\begin{array}{l}0.21 \\
(2.1)\end{array}$ & $\begin{array}{l}0.23 \\
(2.6)\end{array}$ & $\begin{array}{c}0.18 \\
(22.1)\end{array}$ & $\begin{array}{c}0.52 \\
(39.4)\end{array}$ & $\begin{array}{l}0.43 \\
(3.2)\end{array}$ & $\begin{array}{l}0.25 \\
(2.3)\end{array}$ & $\begin{array}{l}0.07 \\
(0.1)\end{array}$ & $\begin{array}{l}0.35 \\
(1.8)\end{array}$ & $\begin{array}{c}0 \\
(0)\end{array}$ & $\begin{array}{l}0.23 \\
(0.1)\end{array}$ & $\begin{array}{l}1.36 \\
(0.4)\end{array}$ & $\begin{array}{c}0.29 \\
(91.5)\end{array}$ \\
\hline Serogroup C & $\begin{array}{c}0.28 \\
(11.6)\end{array}$ & $\begin{array}{c}0.55 \\
(16.8)\end{array}$ & $\begin{array}{l}0.08 \\
(0.8)\end{array}$ & $\begin{array}{l}0.18 \\
(2.1)\end{array}$ & $\begin{array}{c}0.15 \\
(18.1)\end{array}$ & $\begin{array}{c}0.23 \\
(17.2)\end{array}$ & $\begin{array}{l}0.12 \\
(0.9)\end{array}$ & $\begin{array}{l}0.04 \\
(0.4)\end{array}$ & $\begin{array}{c}0 \\
(0)\end{array}$ & $\begin{array}{l}0.13 \\
(0.7)\end{array}$ & $\begin{array}{l}0.32 \\
(0.1)\end{array}$ & $\begin{array}{l}0.48 \\
(0.2)\end{array}$ & $\begin{array}{c}0.00 \\
(0)\end{array}$ & $\begin{array}{c}0.22 \\
(68.9)\end{array}$ \\
\hline Serogroup $Y$ & $\begin{array}{l}0.12 \\
(4.8)\end{array}$ & $\begin{array}{l}0.07 \\
(2.2)\end{array}$ & $\begin{array}{l}0.08 \\
(0.8)\end{array}$ & $\begin{array}{l}0.10 \\
(1.2)\end{array}$ & $\begin{array}{c}0.10 \\
(12.1)\end{array}$ & $\begin{array}{l}0.07 \\
(4.9)\end{array}$ & $\begin{array}{l}0.09 \\
(0.7)\end{array}$ & $\begin{array}{l}0.10 \\
(0.9)\end{array}$ & $\begin{array}{l}0.07 \\
(0.1)\end{array}$ & $\begin{array}{l}0.10 \\
(0.5)\end{array}$ & $\begin{array}{c}0 \\
(0)\end{array}$ & $\begin{array}{l}0.23 \\
(0.1)\end{array}$ & $\begin{array}{c}0.00 \\
(0)\end{array}$ & $\begin{array}{l}0.09 \\
(28.3)\end{array}$ \\
\hline $\begin{array}{l}\text { Serogroup } \\
\text { W-135 }\end{array}$ & $\begin{array}{l}0.04 \\
(1.5)\end{array}$ & $\begin{array}{l}0.02 \\
(0.7)\end{array}$ & $\begin{array}{l}0.02 \\
(0.2)\end{array}$ & $\begin{array}{l}0.03 \\
(0.4)\end{array}$ & $\begin{array}{l}0.05 \\
(5.6)\end{array}$ & $\begin{array}{l}0.02 \\
(1.8)\end{array}$ & $\begin{array}{l}0.04 \\
(0.3)\end{array}$ & $\begin{array}{l}0.01 \\
(0.1)\end{array}$ & $\begin{array}{c}0.00 \\
(0)\end{array}$ & $\begin{array}{c}0.00 \\
(0)\end{array}$ & $\begin{array}{c}0.00 \\
(0)\end{array}$ & $\begin{array}{c}0.00 \\
(0)\end{array}$ & $\begin{array}{c}0.00 \\
(0)\end{array}$ & $\begin{array}{c}0.03 \\
(10.6)\end{array}$ \\
\hline $\begin{array}{l}\text { Other } \\
\text { Serogroups }\end{array}$ & $\begin{array}{l}0.01 \\
(0.2)\end{array}$ & $\begin{array}{l}0.02 \\
(0.7)\end{array}$ & $\begin{array}{l}0.00 \\
(0)\end{array}$ & $\begin{array}{l}0.01 \\
(0.1)\end{array}$ & $\begin{array}{l}0.04 \\
(4.9)\end{array}$ & $\begin{array}{l}0.01 \\
(0.6)\end{array}$ & $\begin{array}{l}0.03 \\
(0.2)\end{array}$ & $\begin{array}{c}0.00 \\
(0)\end{array}$ & $\begin{array}{c}0.00 \\
(0)\end{array}$ & $\begin{array}{l}0.04 \\
(0.2)\end{array}$ & $\begin{array}{c}0.00 \\
(0)\end{array}$ & $\begin{array}{c}0.00 \\
(0)\end{array}$ & $\begin{array}{c}0.00 \\
(0)\end{array}$ & $\begin{array}{l}0.02 \\
(6.9)\end{array}$ \\
\hline $\begin{array}{l}\text { Unknown } \\
\text { Serogroup }\end{array}$ & $\begin{array}{l}0.06 \\
(2.4)\end{array}$ & $\begin{array}{l}0.07 \\
(2.1)\end{array}$ & $\begin{array}{l}0.03 \\
(0.3)\end{array}$ & $\begin{array}{l}0.12 \\
(1.4)\end{array}$ & $\begin{array}{l}0.04 \\
(5)\end{array}$ & $\begin{array}{l}0.05 \\
(3.5)\end{array}$ & $\begin{array}{l}0.03 \\
(0.2)\end{array}$ & $\begin{array}{l}0.10 \\
(0.9)\end{array}$ & $\begin{array}{l}0.15 \\
(0.2)\end{array}$ & $\begin{array}{l}0.31 \\
(1.6)\end{array}$ & $\begin{array}{c}0.00 \\
(0)\end{array}$ & $\begin{array}{l}0.23 \\
(0.1)\end{array}$ & $\begin{array}{c}0.00 \\
(0)\end{array}$ & $\begin{array}{c}0.06 \\
(17.7)\end{array}$ \\
\hline
\end{tabular}


TABLE 5: Invasive meningococcal disease Incidence per 100,000 population in Canada by serogroup and age group, $2007^{(9)}$

\begin{tabular}{|c|c|c|c|c|c|c|c|c|c|c|c|c|}
\hline Serogroup & $<1$ & 1 to 4 & 5 to 9 & 10 to 14 & 15 to 19 & 20 to 24 & 25 to 29 & 30 to 39 & 40 to 59 & $60+$ & Unknown & All Ages \\
\hline $\begin{array}{l}\text { Incidence } \\
\text { (Number of cases) }\end{array}$ & $\begin{array}{l}6.94 \\
(25)\end{array}$ & $\begin{array}{l}1.93 \\
(27)\end{array}$ & $\begin{array}{l}0.78 \\
(14)\end{array}$ & $\begin{array}{c}0.34 \\
(7)\end{array}$ & $\begin{array}{l}1.30 \\
(29)\end{array}$ & $\begin{array}{l}0.93 \\
(21)\end{array}$ & $\begin{array}{l}0.54 \\
(12)\end{array}$ & $\begin{array}{l}0.25 \\
(11)\end{array}$ & $\begin{array}{l}0.45 \\
(45)\end{array}$ & $\begin{array}{l}0.59 \\
(36)\end{array}$ & $\begin{array}{c}0.01 \\
(2)\end{array}$ & $\begin{array}{l}0.70 \\
(229)\end{array}$ \\
\hline Serogroup A & $\begin{array}{l}0.00 \\
(0)\end{array}$ & $\begin{array}{l}0.00 \\
(0)\end{array}$ & $\begin{array}{l}0.00 \\
(0)\end{array}$ & $\begin{array}{c}0.00 \\
(0)\end{array}$ & $\begin{array}{l}0.00 \\
(0)\end{array}$ & $\begin{array}{l}0.00 \\
(0)\end{array}$ & $\begin{array}{l}0.00 \\
(0)\end{array}$ & $\begin{array}{l}0.00 \\
(0)\end{array}$ & $\begin{array}{l}0.00 \\
(0)\end{array}$ & $\begin{array}{l}0.00 \\
(0)\end{array}$ & $\begin{array}{l}0.00 \\
(0)\end{array}$ & $\begin{array}{c}0.00 \\
(0)\end{array}$ \\
\hline Serogroup B & $\begin{array}{l}5.55 \\
(20)\end{array}$ & $\begin{array}{l}1.28 \\
(18)\end{array}$ & $\begin{array}{l}0.61 \\
(11)\end{array}$ & $\begin{array}{l}0.20 \\
(4)\end{array}$ & $\begin{array}{l}0.80 \\
(18)\end{array}$ & $\begin{array}{l}0.66 \\
(15)\end{array}$ & $\begin{array}{c}0.36 \\
(8)\end{array}$ & $\begin{array}{l}0.13 \\
(6)\end{array}$ & $\begin{array}{l}0.23 \\
(23)\end{array}$ & $\begin{array}{c}0.13 \\
(8)\end{array}$ & $\begin{array}{c}0 \\
(0)\end{array}$ & $\begin{array}{l}0.40 \\
(131)\end{array}$ \\
\hline Serogroup C & $\begin{array}{c}0.28 \\
(1)\end{array}$ & $\begin{array}{l}0.21 \\
(3)\end{array}$ & $\begin{array}{c}0.06 \\
(1)\end{array}$ & $\begin{array}{l}0.00 \\
(0)\end{array}$ & $\begin{array}{c}0.00 \\
(0)\end{array}$ & $\begin{array}{c}0.09 \\
(2)\end{array}$ & $\begin{array}{c}0.09 \\
(2)\end{array}$ & $\begin{array}{c}0.02 \\
(1)\end{array}$ & $\begin{array}{l}0.10 \\
(10)\end{array}$ & $\begin{array}{l}0.16 \\
(10)\end{array}$ & $\begin{array}{c}0 \\
(0)\end{array}$ & $\begin{array}{l}0.09 \\
(30)\end{array}$ \\
\hline Serogroup $Y$ & $\begin{array}{l}0.28 \\
(1)\end{array}$ & $\begin{array}{l}0.14 \\
(2)\end{array}$ & $\begin{array}{l}0.00 \\
(0)\end{array}$ & $\begin{array}{l}0.10 \\
(2)\end{array}$ & $\begin{array}{c}0.31 \\
(7)\end{array}$ & $\begin{array}{c}0.09 \\
(2)\end{array}$ & $\begin{array}{l}0.00 \\
(0)\end{array}$ & $\begin{array}{c}0.07 \\
(3)\end{array}$ & $\begin{array}{l}0.06 \\
(6)\end{array}$ & $\begin{array}{l}0.18 \\
(11)\end{array}$ & $\begin{array}{c}0.003 \\
(1)\end{array}$ & $\begin{array}{l}0.11 \\
(35)\end{array}$ \\
\hline $\begin{array}{l}\text { Serogroup } \\
\text { W-135 }\end{array}$ & $\begin{array}{c}0.00 \\
(0)\end{array}$ & $\begin{array}{c}0.14 \\
(2)\end{array}$ & $\begin{array}{l}0.00 \\
(0)\end{array}$ & $\begin{array}{c}0.05 \\
(1)\end{array}$ & $\begin{array}{l}0.05 \\
(1)\end{array}$ & $\begin{array}{c}0.00 \\
(0)\end{array}$ & $\begin{array}{l}0.00 \\
(0)\end{array}$ & $\begin{array}{l}0.00 \\
(0)\end{array}$ & $\begin{array}{c}0.04 \\
(4)\end{array}$ & $\begin{array}{c}0.08 \\
(5)\end{array}$ & $\begin{array}{c}0 \\
(0)\end{array}$ & $\begin{array}{l}0.04 \\
(13)\end{array}$ \\
\hline $\begin{array}{l}\text { Other } \\
\text { serogroups }\end{array}$ & $\begin{array}{c}0.00 \\
(0)\end{array}$ & $\begin{array}{c}0.00 \\
(0)\end{array}$ & $\begin{array}{l}0.00 \\
(0)\end{array}$ & $\begin{array}{l}0.00 \\
(0)\end{array}$ & $\begin{array}{l}0.05 \\
(1)\end{array}$ & $\begin{array}{c}0.04 \\
(1)\end{array}$ & $\begin{array}{c}0.00 \\
(0)\end{array}$ & $\begin{array}{l}0.00 \\
(0)\end{array}$ & $\begin{array}{c}0.01 \\
(1)\end{array}$ & $\begin{array}{c}0.02 \\
(1)\end{array}$ & $\begin{array}{c}0 \\
(0)\end{array}$ & $\begin{array}{c}0.01 \\
(4)\end{array}$ \\
\hline $\begin{array}{l}\text { Unknown } \\
\text { serogroup }\end{array}$ & $\begin{array}{c}0.83 \\
(3)\end{array}$ & $\begin{array}{c}0.14 \\
(2)\end{array}$ & $\begin{array}{c}0.11 \\
(2)\end{array}$ & $\begin{array}{c}0.00 \\
(0)\end{array}$ & $\begin{array}{c}0.09 \\
(2)\end{array}$ & $\begin{array}{c}0.04 \\
(1)\end{array}$ & $\begin{array}{c}0.09 \\
(2)\end{array}$ & $\begin{array}{c}0.02 \\
(1)\end{array}$ & $\begin{array}{c}0.01 \\
(1)\end{array}$ & $\begin{array}{c}0.02 \\
(1)\end{array}$ & $\begin{array}{c}0.003 \\
(1)\end{array}$ & $\begin{array}{l}0.05 \\
(16)\end{array}$ \\
\hline
\end{tabular}

\section{Vaccine}

\section{IV.1 MENINGOCOCCAL CONJUGATE IMMUNIZATION SCHEDULES USED IN CANADA}

Table 6 provides an overview of the meningococcal vaccines available in Canada. Table 7 provides a summary of the routine childhood schedules being used in the provinces and territories as of February 2011. In its April 2009 statement,
$\mathrm{NACl}$ recommended the inclusion of a dose of conjugate meningococcal vaccine in adolescence with the choice of product determined by local epidemiology. Subsequently, some provinces and territories changed to using the quadrivalent conjugate meningococcal vaccine, Men-C-ACYW-135-D (Menactra ${ }^{\mathrm{TM}}$ ) from the monovalent meningococcal $\mathrm{C}$ conjugate vaccine for their adolescent program. 
TABLE 6: Summary of meningococcal vaccines available in Canada.

\begin{tabular}{|c|c|c|c|c|c|c|}
\hline $\begin{array}{l}\text { Name } \\
\text { of product }\end{array}$ & $\begin{array}{l}\text { Type } \\
\text { of vaccine }\end{array}$ & Manufacturer & $\begin{array}{l}\text { Concentration of } \\
\text { polysaccharide(s) }\end{array}$ & $\begin{array}{l}\text { Protein } \\
\text { carrier }\end{array}$ & Administration & $\begin{array}{l}\text { Manufacturer's } \\
\text { Schedule }\end{array}$ \\
\hline \multicolumn{7}{|c|}{ Quadrivalent Meningococcal Vaccines (conjugate and polysaccharide): } \\
\hline Menactra ${ }^{\mathrm{TM}}$ & $\begin{array}{l}\text { Conjugate A, } \\
\text { C, Y, W-135 }\end{array}$ & sanofi pasteur & $\begin{array}{l}4 \mu \mathrm{g} \text { of each } \\
\text { serogroup }\end{array}$ & $\begin{array}{l}48 \mu \mathrm{g} \text { of } \\
\text { diphtheria toxoid }\end{array}$ & $0.5 \mathrm{ml} \mathrm{IM}$ & 2 to 55 years of age - one dose \\
\hline Menveo TM & $\begin{array}{l}\text { Conjugate A, } \\
\text { C, Y, W-135 }\end{array}$ & Novartis & $\begin{array}{l}10 \mu g \text { of } \\
\text { serogroup } A \\
5 \mu g \text { of each of } \\
\text { serogroups } C \text {, } \\
W 135 \text { and } Y\end{array}$ & $\begin{array}{l}\text { Varying amounts } \\
\text { of CRM } \\
\text { conjugated } \\
\text { to each } \\
\text { polysaccharide }\end{array}$ & $\begin{array}{l}0.5 \mathrm{ml} \mathrm{IM} \\
\text { Requires } \\
\text { reconstitution }\end{array}$ & 2 to 55 years of age - one dose \\
\hline $\begin{array}{l}\text { Menomune }^{\mathrm{TM}} \\
\mathrm{A} / \mathrm{C} / \mathrm{Y} / \mathrm{W}-135\end{array}$ & $\begin{array}{l}\text { Polysaccharide } \\
\text { A, C, Y, W-135 }\end{array}$ & $\begin{array}{l}\text { sanofi } \\
\text { pasteur }\end{array}$ & $\begin{array}{l}50 \mu \mathrm{g} \text { of each } \\
\text { serogroup }\end{array}$ & Not applicable & $\begin{array}{l}0.5 \mathrm{ml} \mathrm{SQ} \\
\text { Requires } \\
\text { reconstitution }\end{array}$ & $\begin{array}{l}\text { Children } 2 \text { years of age and older, } \\
\text { adolescents and adults - one dose; } \\
\text { repeat at interval based on age if } \\
\text { at ongoing risk; can be used for } \\
\text { children } 3 \text { months of age and older } \\
\text { for serogroup A protection }\end{array}$ \\
\hline \multicolumn{7}{|c|}{ Monovalent Meningococcal C Conjugate Vaccines: } \\
\hline Meningitec $^{\mathrm{TM}}$ & Conjugate $\mathrm{C}$ & $\begin{array}{l}\text { Pfizer } \\
\text { Canada }\end{array}$ & $10 \mu \mathrm{g}$ & $15 \mu \mathrm{g} \mathrm{CRM}{ }_{197}$ & $0.5 \mathrm{ml} \mathrm{IM}$ & $\begin{array}{l}\text { Infants } 2-12 \text { months of age - } \\
2 \text { doses starting no earlier than } 2 \\
\text { months of age and separated by } \\
\text { at least two months, with a } \\
\text { booster dose in accordance with } \\
\text { official recommendations, preferably } \\
\text { at about } 12 \text { months of age; } \\
\text { Children } 1 \text { year of age and older, } \\
\text { adolescents and adults - one dose }\end{array}$ \\
\hline Menjugate $^{\circledR}$ & Conjugate C & Novartis & $10 \mu \mathrm{g}$ & $\begin{array}{l}12.5-25 \mu \mathrm{g} \\
\mathrm{CRM}_{197}\end{array}$ & $\begin{array}{l}0.5 \mathrm{ml} \mathrm{IM} \\
\text { Requires } \\
\text { reconstitution }\end{array}$ & $\begin{array}{l}\text { Infants 2-12 months of age - } \\
3 \text { doses starting no earlier than } 2 \\
\text { months of age and separated by } \\
\text { at least one month, with a booster } \\
\text { dose in accordance with } \mathrm{NACl} \\
\text { recommendations; }{ }^{*} \text { Children } 1 \\
\text { year of age and older, } \\
\text { adolescents and adults - one dose }\end{array}$ \\
\hline Neis Vac-C ${ }^{\circledast}$ & Conjugate $\mathrm{C}$ & $\begin{array}{l}\text { Baxter } \\
\text { (distributed } \\
\text { by Glaxo } \\
\text { SmithKline) }\end{array}$ & $10 \mu \mathrm{g}$ & $\begin{array}{l}10-20 \mu \mathrm{g} \\
\text { tetanus toxoid }\end{array}$ & $0.5 \mathrm{ml} \mathrm{IM}$ & $\begin{array}{l}\text { Infants } 2-12 \text { months of age - } \\
2 \text { doses starting no earlier than } \\
2 \text { months of age and separated } \\
\text { by at least two months, with one } \\
\text { dose after } 5 \text { months of age; if } \\
\text { primary series completed before } \\
5 \text { months of age give booster in } \\
\text { second year of life approximately } \\
1 \text { year from last dose; } \\
\text { Children } 1 \text { year of age and older, } \\
\text { adolescents and adults - one dose }\end{array}$ \\
\hline
\end{tabular}

IM - intramuscularly

SQ - subcutaneously

$\mathrm{CRM}_{197}$ Corynebacterium diphtheriae cross reacting material 197

*Note: For children receiving meningococcal $\mathrm{C}$ conjugate vaccines in infancy, $\mathrm{NACl}$ recommends an additional dose of meningococcal $C$ conjugate vaccines in the second year of life (from 12 to 23 months of age)

Note that NACl's recommendations may differ from the manufacturer's recommendations. NACl's recommendations are outlined in the Canadian Immunization Guide and NACl meningococcal statements. 
TABLE 7: Summary of Current Meningococcal Immunization Programs in Canada, 2011(10)

\begin{tabular}{|c|c|c|c|c|}
\hline Province/ Territory & $\begin{array}{l}\text { Current infant } \\
\text { program using } \\
\text { meningococcal C } \\
\text { conjugate }\end{array}$ & $\begin{array}{l}\text { Date of } \\
\text { implementation } \\
\text { of current infant } \\
\text { program }\end{array}$ & $\begin{array}{l}\text { Current adolescent } \\
\text { program using (C) } \\
\text { meningococcal C } \\
\text { conjugate or } \\
\text { (Q) C ACYW-135 }\end{array}$ & $\begin{array}{l}\text { Date of } \\
\text { implementation } \\
\text { of current } \\
\text { adolescent program }\end{array}$ \\
\hline British Columbia & 2,12 months & 2005 & (C) Grade 6 & 2003 \\
\hline Alberta & $2,4,12$ months & 2007 & (Q) Grade 9 & 2011 \\
\hline Saskatchewan & 12 months & 2004 & (Q) Grade 6 & 2011 \\
\hline Manitoba & 12 months & 2009 & (C) Grade 4 & 2004 \\
\hline Ontario & 12 months & 2004 & (Q) Grade 7 & 2009 \\
\hline Quebec & 12 months & 2002 & (C) $<18$ years & 2002 \\
\hline New Brunswick & 12 months & 2004 & (Q) Grade 9 & 2007 \\
\hline Nova Scotia & 12 months & 2005 & (C) Grade 7 & 2010 \\
\hline Prince Edward Island & 12 months & 2003 & (Q) Grade 9 & 2006 \\
\hline $\begin{array}{l}\text { Newfoundland } \\
\text { and Labrador }\end{array}$ & 12 months & 2005 & (Q) Grade 4 & 2007 \\
\hline Northwest Territories & 2, 12 months & 2004 & (C) Grade 9 & 2008 \\
\hline Yukon & 2, 12 months & 2009 & (C) Grade 6 & 2006 \\
\hline Nunavut & 12 months & 2007 & (C) Grade 9 & 2006 \\
\hline
\end{tabular}

\section{IV.2 MEN-C-ACYW-135-CRM (MENVEOTM) DESCRIPTION AND COMPOSITION}

Men-C-ACYW-135-CRM (Menveo ${ }^{\mathrm{TM}}$ ) contains capsular polysaccharides from serogroups A $(10 \mu \mathrm{g}), \mathrm{C}(5 \mu \mathrm{g}), \mathrm{W} 135(5 \mu \mathrm{g})$ and $Y(5 \mu \mathrm{g})$. Each serogroup is individually conjugated to $\mathrm{CRM}_{197}$, a natural mutant of the diphtheria toxin which serves as a carrier protein. The vaccine contains no adjuvant, preservatives, or thimerosal. The container closures do not contain latex.

The vaccine is packaged in two separate vials (one containing conjugate meningococcal C, W135, Y as a liquid and the other containing conjugate meningococcal $A$ as a powder) that are mixed prior to administration. All the liquid from the meningococcal C, W135,Y vial is withdrawn and injected into the vial containing the lyophilized meningococcal $A$ powder and then shaken vigorously until the components dissolve to yield a solution that is a clear, colourless liquid. Subsequently, $0.5 \mathrm{ml}$ of the reconstituted solution is withdrawn from the vial that previously contained the meningococcal $A$ powder. There may be a small amount of reconstituted vaccine remaining in the vial after the $0.5 \mathrm{ml}$ is withdrawn.

\section{IV.3 EFFICACY AND EFFECTIVENESS OF MEN-C-ACYW-135-CRM (MENVEOTM) AND MEN-C-ACYW-135-D
(MENACTRATM)}

It is generally not feasible to perform efficacy studies of conjugate meningococcal vaccines because the disease is relatively rare, and prohibitively large populations would have to be studied. Regulatory authorities have established immunogenicity criteria as correlates of protection from $I M D$, and these correlates are used as outcome measures in clinical trials which compare new conjugate meningococcal vaccines to previously authorized meningococcal vaccines.

\section{IV.3.1 Men-C-ACYW-135-CRM (Menveo'TM)}

There is no efficacy or effectiveness data available for Men-C-ACYW-135-CRM (Menveo ${ }^{\mathrm{TM}}$ ).

\section{IV.3.2 Men-C-ACYW-135-D (Menactra ${ }^{\text {TM}}$ )} Effectiveness data for Men-C-ACYW-135-D (Menactra ${ }^{\mathrm{TM}}$ ) is now becoming available in the United States after four years of increasing use, primarily among those 11-18 years of age. The Active Bacterial Core (ABC) and MeningNet surveillance systems (these systems represent $54 \%$ of the US population) 
identified 14 reported cases of IMD (8 serogroup $C$ and 6 serogroup Y) from January 1, 2005 to December 31, 2008 among individuals previously vaccinated with Men-C-ACYW135-D (Menactra $\left.{ }^{\mathrm{TM}}\right)$. The median age of the cases at disease onset was 19 years (range 15-21 years) and the median time from Three cases were fatal resulting in a case fatality rate of $21 \%$. Based on the number of vaccine failures, early estimates of vaccine effectiveness of Men-C-ACYW-135-D (Menactra ${ }^{\mathrm{TM}}$ ) within 3-4 years of vaccination are 80 to $85 \%{ }^{(11)}$

Preliminary results from a case control study in the US involving 108 cases and 158 controls ranging in age from 10 to 23 years demonstrated a $78 \%$ overall vaccine effectiveness for Men-C-ACYW-135-D (Menactra ${ }^{\mathrm{TM}}$ )(95\% Cl: 29 to $\left.93 \%\right)$ (serogroup C 77\% (95\% Cl: 14 to 94\%); serogroup Y 88\% (95\% Cl: -23 to $99 \%)$. These preliminary results indicated that vaccine effectiveness waned over time when assessed up to less than 5 years post vaccination. ${ }^{(12)(13)}$

It should be noted that individual vaccine effectiveness may not predict the impact on meningococcal disease burden in the community due to the additional benefit conferred by herd immunity. This is particularly true for serogroup $\mathrm{C}$ against which large numbers of Canadian children and adolescents have been vaccinated.

\section{IV.4 IMMUNOLOGICAL CORRELATES OF PROTECTION}

Regulatory approval of conjugated vaccines for meningococcal disease has been based primarily on short-term immunogenicity studies. ${ }^{(14)}$ It would be difficult to conduct efficacy and effectiveness studies because of the relative rarity of meningococcal disease. The immunogenicity outcomes that are most commonly used are serum bactericidal antibody (SBA) levels using either human or rabbit serum as a source of complement, and enzyme linked immunosorbent assays (ELISA).

SBA levels are the standard measure used to determine susceptibility and immunity to IMD. These measure the titres of bactericidal antibody in a serum sample that can kill a proportion of a particular strain of N.meningitidis in a specified time frame. This test is done in vitro in the presence of added complement. Traditionally, human serum has been the exogenous complement source for this assay, and most tests of Men-C-ACYW-135-CRM (Menveo ${ }^{\mathrm{TM}}$ ) use this methodology. Using human serum complement, a human serum bactericidal antibody (hSBA) titre of $\geq 1: 4$ has been found to correlate with protection against serogroup $C$ meningococcal disease ${ }^{(15)}$ and hSBA $\geq 1: 4$ has also been used as a correlate for serogoup A meningococcal disease. There are no confirmed immunological correlates of protection for serogroups $Y$ or W135. Baby rabbit serum, which is more readily available, has replaced human complement in some studies. A baby rabbit serum bactericidal antibody ( $\mathrm{rSBA}$ ) titre of $\geq 1: 8$ has been proposed as a correlate of short-term immunity against serogroup C IMD. (16) Geometric mean titres (GMTs) of SBA are also reported as a measure of immune response to meningococcal vaccine. ELISA tests are used to determine the serogroup $C$ meningococcal polysaccharide specific IG concentrations ${ }^{(17)}$ which can be expressed as geometric mean antibody concentrations (GMC). ELISA methodology is also available to assess meningococcal C IgG antibody avidity. ${ }^{(18)}$

Studies of meningococcal vaccines may also use "seroresponse" as an immunological indicator. Seroresponse is defined as the percentage of people who meet the following criteria:

- for subjects with an hSBA titre $<1: 4$ at baseline, a post-vaccination hSBA titre $>=1: 8$;

- for subjects with an hSBA titre of $>=1: 4$ at baseline, a post-vaccination titre of at least 4 times their baseline titre.

Seroresponse endpoints can be found in the publications referred to in this statement, but will generally not be summarized in this $\mathrm{NACl}$ statement.

Statistical analysis of immunological data uses the concepts of inferiority, non-inferiority and superiority for GMTs, hSBA titres and seroresponse. For GMTs these are defined based on the ratio of GMTs for the study vaccine and the comparator vaccine. The two vaccines were considered non-inferior if the lower limit of the 2-sided 95\% confidence interval around the ratio was $>0.5$ and superior if this value was $>1$. For the hSBA titre and seroresponse, the difference in the proportion of people achieving this response using the study vaccine and the comparator vaccine are calculated. Non-inferiority is defined by the lower limit of the 2-sided $95 \%$ confidence interval greater than $-10 \%$ and superiority was defined as a lower limit of greater than $0 \%$.

It is well established that vaccination with conjugate meningococcal vaccine primes the immune system for memory and induces good anamnestic responses after challenges with meningococcal $\mathrm{C}$ polysaccharide or conjugate vaccines. ${ }^{(19)-(23)}$ However, because of the short incubation period of IMD (range 2 to 10 days, commonly 3 to 4 days), ${ }^{(24)}$ it is now generally accepted that the anamnestic response cannot be relied upon to prevent disease and that circulating antibodies are necessary for protection. ${ }^{(5)}$ Therefore, immunogenicity studies likely predict short-term effectiveness; however, their ability to determine long-term effectiveness is uncertain as antibody levels decline post-vaccination (25)-(27) 
even within 6-8 months post-vaccination in early childhood. ${ }^{(23)(28)}$ It is hoped that the higher the antibody titre achieved post-vaccination, the longer circulating antibodies will persist and the longer the duration of protection from vaccination, but evidence is currently awaited to support this idea.

Immunogenicity studies do not predict the impact of vaccination on carriage and herd immunity. Herd immunity may offer protection if sufficient numbers of people are vaccinated, even when individual protection has waned. This has been illustrated in research conducted by Campbell et al. ${ }^{(29)}$ Meningococcal $C$ conjugate vaccine was introduced into the United Kingdom in 1999 using a primary immunization schedule of 2, 3 and 4 months for infants and a single dose catch-up campaign for 1-18 year-olds. The catch-up was extended to those up to 25 years of age in January 2002. The researchers demonstrated that vaccine effectiveness in infants was $97 \%$ (95\% Cl: $91-99 \%$ ) within one year of vaccination, but fell to $68 \%$ (95\% Cl: -63 to 90\%) after 1 year and up to 10 years post-vaccination. Nonetheless, rates of meningococcal disease caused by serogroup $C$ in infants under 1 year of age fell by $99 \%$ between 1998/1999 and 2007/2008 (from 16.63 to 0.15 per 100,000). This sustained decline in IMD caused by serogroup $\mathrm{C}$ despite falling vaccine effectiveness in this age group is attributed to the impact of herd immunity induced by offering vaccine to adolescents and possibly young adults.

\section{IV.5 IMMUNOGENICITY OF MEN-C- ACYW-135-CRM (MENVEOTM)}

A total of 24 trials involving Men-C-ACYW-135-CRM are ongoing or completed. These include approximately 18500 individuals who received a formulation of Men-C-ACYW-135-CRM. Of these, 14000 received the final formulation of Menveo ${ }^{\mathrm{TM}}$ that has been authorized for use $(10 \mu \mathrm{g}$ serogroup $A$ and $5 \mu \mathrm{g}$ of each of serogroups C, W135, Y without adjuvant). ${ }^{(30)}$ An aluminum-adjuvanted formulation was also tested, however the final formulation does not contain an adjuvant because the adjuvant was not found to significantly improve the immunogenicity of the vaccine.

In the sections below, information related to the immunogenicity of Men-C-ACYW-135-CRM in infants, toddlers, adolescents and adults is reviewed. It should be noted that in these studies, blinding of those administering the vaccine is not possible due to the unique appearance of Men-C-ACYW-135-CRM, including the requirement to reconstitute the product before administration. The studies are summarized in Table 8.

\section{IV.5.1 Children less than 2 years of age}

Two phase II randomized controlled trials in infants have been conducted, both involving subjects from the UK and Canada. In each study the vaccines were administered concomitantly with infant vaccines routinely used in those jurisdictions. The first study by Snape et al(28) enrolled a total of 421 infants who were randomized to receive an earlier formulation of Menveo ${ }^{\mathrm{TM}}$ which contained an aluminium phosphate adjuvant (Men-C-ACYW-135-CRM with adjuvant). Various schedules were studied as follows: 2, 3, 4 months of age used in the UK; 2, 4, 6 months of age used in Canada; and 2 and 4 months of age used in both the UK and Canada. The results were compared to a monovalent meningococcal $\mathrm{C}$ conjugate vaccine (Menjugate ${ }^{\circledR}$ - Novartis Vaccines) given at 2 and 4 months of age in the UK. Immunity was measured using human complement serum bactericidal activity (hSBA) of $>=1: 4$. At one month after completing their vaccination series, a higher proportion of subjects achieved this level of immunity with the three dose schedules $(2,3,4$ months or 2,4 , 6 months of age) than with the two dose schedules ( 2 , 4 months of age) for all four serogroups. The geometric mean titres (GMTs) were also higher with the three dose schedule than a two dose schedule. Except for serogroup A, the 2, 4, 6 month Canadian schedule achieved slightly higher proportions of infants with immunity and slightly higher GMTs than the 2, 3, 4 month UK schedule. For the 2, 4, 6 month Canadian schedule, the percent of infants who achieved an hSBA titre of $>=1: 4$ at 1 month after completion of the series was as follows:

- serogroup A 81\% (95\% Cl: 71-89\%);

- serogroup C 98\% (95\% Cl: 92-100\%);

- serogroup W135 99\% (95\% Cl: 93-100\%);

- serogroup Y 98\% (Cl: 92-100\%).

However by 12 months of age, the percentage of infants with this titre had fallen, particularly for serogroups $A$ and $C$, with the percentage of vaccinated children with a hSBA titre of $\geq 1: 4$ as follows:

- serogroup A 41\% (95\% Cl: 26-57\%);

- serogroup C 70\% (95\% Cl: 54-82\%);

- serogroup W135 95\% (95\% Cl: 83-99\%);

- serogroup Y 87\% (Cl: 74-95\%).

GMTs had also fallen substantially from one month post vaccination at 2, 4 and 6 months compared to 12 months of age. As an example, for serogroup C the GMT was 124 (95\%Cl: 89-172) at one month post vaccination, and 13 (95\% $\mathrm{Cl}: 8.72-18)$ at 12 months of age. 
By contrast, the monovalent meningococcal $\mathrm{C}$ conjugate vaccine (Menjugate ${ }^{\circledR}$ ), which contains double the amount of polysaccharide for serogroup C compared to Men-C-ACYW135-CRM with adjuvant, given at 2 and 4 months achieved the highest GMTs for serogroup C as follows: 339 (95\% Cl: 209-551) at 5 months of age (one month post-vaccination), and 26 (95\% Cl: 17-39) at 12 months of age. The percentages of infants with a titre of $>=1: 4$ was $98 \%$ ( $95 \% \mathrm{Cl}: 87-100 \%$ ) at one month post-vaccination and $89 \%$ (95\% Cl: 75-97\%) at 12 months of age.

One month following a challenge with either another dose of Men-C-ACYW-135-CRM with adjuvant or one-fifth of a dose of an unconjugated polysaccharide quadrivalent vaccine (Men-P-ACYW-135 - Menomune ${ }^{\text {TM }}$, sanofi pasteur) at 12 months of age, all schedules demonstrated a good booster response. The highest response for serogroup $\mathrm{C}$ one month after the 12 month Men-C-ACYW-135-CRM with adjuvant dose was achieved in toddlers who had received the monovalent meningococcal $C$ conjugate vaccine at 2 and 4 months of age (GMTs for serogroup C were 912 (95\% Cl: 538-1545)). The Men-C-ACYW-135-CRM with adjuvant was not used as a booster dose after the 2, 4 and 6 month Canadian primary series, but with the 2, 3, and 4 month UK primary series, the 12 month booster of Men-C-ACYW-135-CRM with adjuvant achieved a GMT of 429 (95\% Cl:288-639) for serogroup C one month post-vaccination.

In the group that received monovalent meningococcal $C$ conjugate vaccine at 2 and 4 months of age and then one dose of Men-C-ACYW-135-CRM with adjuvant at 12 months of age, the following percentage of toddlers achieved a titre of $>=1: 4$ for serogroups $A, Y$ and $W 135$ :

- serogroup A 59\% (95\% Cl: 42-75\%);

- serogroup W135 86\% (95\% Cl: 71-95\%);

- serogroup Y 86\% (Cl: 71-95\%).

However, the GMTs were much lower in this group for serogroups A, Y and W135 than in those groups who received the booster of Men-C-ACYW-135-CRM with adjuvant at 12 months and had received 2 or 3 doses of the same vaccine in infancy. This finding suggests that the duration of protection with one toddler dose of Men-C-ACYW-135-CRM with adjuvant may be shorter than when using this vaccine to prime in infancy and giving a booster dose in the second year of life.

The second study by Perrett et al.(31) enrolled 180 children in the UK and Canada using a similar protocol to the Snape et al. study described above ${ }^{(28)}$. In the Perrett et al study, children received non-adjuvanted Men-C-ACYW-135-CRM, which is the final formulation of Menveo ${ }^{\mathrm{TM}}$, given at 2 and 4 months of age with other routine infant vaccines. Responses at 1 month post-vaccination (5 months of age) were slightly higher in the Canadian arm of the study than in the UK arm with the percentage of infants who achieved a hSBA of $>=1: 4$ in the Canadian arm as follows:

- serogroup A 57\% (95\% Cl: 45-67\%);

- serogroup C 93\% (95\% Cl: 85-97\%);

- serogroup W135; $95 \%$ (95\% Cl: 87-99\%);

- serogroup Y 91\% (Cl: 82-96\%).

Similar to the Snape et al study, by 12 months of age, the percentage of infants and children with an hSBA titre of $>=1: 4$ had fallen substantially as follows:

- serogroup A 3\% (95\% Cl: 0.067-14\%);

- serogroup C 33\% (95\% Cl: 19-49\%);

- serogroup W135 69\% (95\% Cl: 51-83\%);

- serogroup Y 63\% (Cl: 46-78\%).

GMTs also fell from one month post vaccination to 12 months of age. Using serogroup $C$ as an example, the GMT was 69 (95\% Cl: 50-95) at one month post vaccination (5 months of age), and 4.07 (95\% Cl: 2.73-6.06) at 12 months of age.

Vaccination at 12 months with either a booster dose of Men-C-ACYW-135-CRM (Menveo ${ }^{\mathrm{TM}}$ ) or one fifth of a dose of an unconjugated quadrivalent polysaccharide meningococcal vaccine (Menomune ${ }^{\mathrm{TM}}$ ) resulted in boosting for all serogroups and high rates of seroprotection. One month after the booster dose of Men-C-ACYW-135-CRM (Menveo ${ }^{\mathrm{TM}}$ ) in the Canadian arm of the study, the GMT was 258 (95\% Cl:156-426) for serogroup C.

In a study involving 175 children, Halperin et al., ${ }^{(32)}$ compared the immunogenicity in the following three groups:

- two doses of Men-C-ACYW-135-CRM (Menveo ${ }^{\text {TM}}$ ) at 6 and 12 months;

- one dose of Men-C-ACYW-135-CRM (Menveo ${ }^{\mathrm{TM}}$ ) at 12 months; and

- a dose of monovalent meningococcal $\mathrm{C}$ conjugate vaccine (Menjugate ${ }^{\mathrm{TM}}$ ) at 12 months followed by a dose of Men-C-ACYW-135-CRM (Menveo ${ }^{\mathrm{TM}}$ ) at 18 months.

Concomitantly administered vaccines included Pentace ${ }^{\mathrm{TM}}$ (DTaP-IPV-Hib) (sanofi pasteur) and Prevnar ${ }^{\circledR}$ (PCV-7) (Pfizer).

The two doses of Men-C-ACYW-135-CRM (Menveo ${ }^{\mathrm{TM}}$ ) at 6 and 12 months resulted in 100\% of recipients achieving an hSBA titre of $>=1: 4$ for serogroups C (95\% Cl: 94-100\%), W135 (95\% Cl: 93-100\%) and Y (95\% Cl: 94-100\%), and $87 \%$ 
(95\% Cl: 75-95\%) achieving this titre for serogroup A when measured at approximately 28 days after the second dose. This schedule induced the highest GMTs for all serogroups except for serogroup $C$, where the schedule using a single dose of monovalent meningococcal $\mathrm{C}$ conjugate vaccine at 12 months and the Men-C-ACYW-135-CRM (Menveo ${ }^{\text {TM}}$ ) at 18 months induced a higher response. The GMTs for serogroup $C 28$ days after completing the schedules were as follows:

- 314 (95\% Cl: 234-421) for Men-C-ACYW-135-CRM at 6 and 12 months; versus

- 679 (95\% Cl: 479-962) for monovalent meningococcal C conjugate vaccine at 12 months and Men-C-ACYW-135-CRM at 18 months.

For serogroup C, the Men-C-ACYW-135-CRM (Menveo ${ }^{\mathrm{TM}}$ ) at 12 months and the monovalent $C$ meningococcal vaccine (Menjugate ${ }^{\mathrm{TM}}$ ) at 12 months induced similar GMTs of 40 (95\% Cl: 29-53 and 30-53 respectively) when measured 28 days post-vaccination, and the percentages of children achieving a titre of $>=1: 4$ were similar at 28 days post-vaccination $(96 \%$ (95\% Cl: 87-100\%) for Men-C-ACYW-135-CRM and 94\% (95\% Cl: 82-99\%) for the monovalent meningococcal C conjugate vaccine). For serogroups $A, W 135$ and $Y$, the immune response was similar when the Men-C-ACYW-135-CRM (Menveo ${ }^{\text {TM}}$ ) was given at 12 month or at 18 months. Approximately 28 days after the vaccine was given at 12 months, the percentages of children with an hSBA titre of $>=1: 4$ were as follows:

- serogroup A 73\% (95\% Cl: 59-84\%);

- serogroup W135 94\% (95\% Cl: 82-99\%);

- serogroup Y 78\% (95\% Cl: 65-88\%).

In an abstract by Vesikari et al. ${ }^{(33)}$ a dose-finding study which enrolled 620 toddlers aged 12-16 months was reported.

These children were randomized to receive one or two doses of different formulations of the vaccine. Using the vaccine formulation chosen for further development, the range of hSBA GMTs for the various serogroups was 5.2-12 after one dose and 28-76 after two doses. The percentage of subjects with an hSBA titre of $>=1: 4$ for the various serotypes was $49-70 \%$ after one dose and $91-96 \%$ after two doses.

\section{IV.5.2 Children 2-10 years of age}

A study by Black et al. ${ }^{(27)}$ involving 619 children 2-10 years of age compared the immune response of Men-C-ACYW-135-CRM (Menveo ${ }^{T M}$ ) to the unconjugated polysaccharide quadrivalent vaccine (Men-P-ACYW-135 - Menomune ${ }^{\mathrm{TM}}$ ). The percentage of children with an hSBA titre $>=1: 4$ was statistically superior for Men-C-ACYW-135-CRM (Menveo ${ }^{\mathrm{TM}}$ ) compared to Men-P-ACYW-135 (Menomune ${ }^{\mathrm{TM}}$ ) at both 1 and 12 months post-vaccination. The GMTs were also statistically significantly higher for all serogroups in the Men-C-ACYW-135-CRM (Menveo ${ }^{\mathrm{TM}}$ ) group compared to the Men-P-ACYW-135 (Menomune ${ }^{\mathrm{TM}}$ ) group at 1 month post-vaccination and for serogroups $A, W 135$ and $Y$ at 12 months post-vaccination.

For Men-P-ACYW-135 (Menomune ${ }^{\mathrm{TM}}$ ) there was a decline in immune response for all serogroups from 1 month to 12 months post-vaccination. For Men-C-ACYW-135-CRM (Menveo ${ }^{\mathrm{TM}}$ ) there was a decline in immune response from one month post-vaccination to 12 month post-vaccination for serogroups $A$ and $C$. The percent achieving an hSBA titre $>=1: 4$ at one and 12 month respectively after receiving Men-C-ACYW-135-CRM (Menveo ${ }^{\mathrm{TM}}$ ) for each serogroup was as follows:

- serogroup A 82\% (95\% Cl: 77-87\%) at 1 month and $28 \%$ (95\% Cl: 23-34\%) at 12 months;

- serogroup C 83\% (95\% Cl: 78-87\%) at 1 month and 68\% (95\% Cl: 62-74\%) at 12 months;

- serogroup W135 95\% (95\% Cl: 91-97\%) at 1 month and $94 \%$ (95\% Cl: 90-97\%) at 12 months;

- serogroup Y $91 \%(\mathrm{Cl}: 87-94 \%)$ at 1 month and $86 \%$ (95\% Cl: 81-90\%) at 12 months.

A study by Halperin et al compared Men-C-ACYW-135-CRM (Menveo $^{\text {TM}}$ ) to Men-C-ACYW-135-D (Menactra ${ }^{\text {TM}}$ ) in 2907 children in two age groups: $2-5$ years of age and 6-10 years of age. ${ }^{(30)(34)}$ Some of the $2-5$ year age group received two doses of Men-C-ACYW-135-CRM given 60 days apart.Using a single dose and measuring the hSBA one month postvaccination for both age groups, the percentage achieving a titre of $>=1: 8$ with Men-C-ACYW-135-CRM compared to Men-C-ACYW-135-D was lower for serogroup A, non-inferior for serogroup $C$ and statistically superior for serogroups W135 and $Y$. The percentage of children 2-5 years of age achieving an $\mathrm{hSBA}$ titre of $>=1: 8$ one month after vaccination with Men-C-ACYW-135-CRM and Men-C-ACYW-135-D respectively was as follows:

- serogroup A $72 \%$ and $78 \%$;

- serogroup C 68\% and 64\%;

- serogroup W135 90\% and 75\%;

- serogroup Y $76 \%$ and $57 \%$. 
The percentage of children 6-10 years of age achieving an hSBA titre of $>=1: 8$ one month after vaccination with Men-C-ACYW-135-CRM and Men-C-ACYW-135-D respectively was as follows:

- serogroup A 77\% and 83\%;

- serogroup C $77 \%$ and $74 \%$;

- serogroup W135 91\% and 84\%;

- serogroup Y $79 \%$ and $63 \%$.

Comparison of GMTs for both age groups combined reveal that Men-C-ACYW-135-CRM is non-inferior to Men-C-ACYW-135-D for serogroup $A$, and statistically superior for serogroups $C$, W135 and Y. The 2-5 year olds who received two doses of Men-C-ACYW-135-CRM had much higher GMTs for all serogroups and a higher percentage of children achieved a titre of $>=1: 8$ for all serogroups compared to children receiving a single dose of Men-C-ACYW-135-CRM.

\section{IV.5.3 Adolescents}

A phase II study conducted by Jackson et al. ${ }^{(35)}$ provides data on 524 US adolescents aged 11-17 years randomized in two phases to receive the earlier formulation of Menveo ${ }^{\mathrm{TM}}$ with the aluminum phosphate adjuvant (Men-C-ACYW-135-CRM with adjuvant) or the authorized formulation of Menveo ${ }^{\mathrm{TM}}$ without the adjuvant (Men-C-ACYW-135-CRM) each compared to the unconjugated polysaccharide quadrivalent meningococcal vaccine (Men-P-ACYW-135 - Menomune ${ }^{\mathrm{TM}}$ ). At one month post-vaccination based on GMTs and the percentage who achieved an hSBA titre of $>=1: 4$, the adjuvanted and unadjuvanted formulations had similar serological responses. Based on immunogenicity measures at 1 month post-vaccination, Men-C-ACYW-135-CRM with or without the adjuvant performed significantly better than Men-P-ACYW-135 (Menomune ${ }^{\text {TM}}$ ) for almost every comparison of the four serogroups.

The percentage of adolescents achieving an hSBA titre of $>=1: 8$ at one month post-vaccination with the non-adjuvanted formulation of MenACW-CRM (the authorized formulation of Menveo ${ }^{\mathrm{TM}}$ ) was as follows:

- serogroup A $81 \%$ (95\% Cl: 74-87\%);

- serogroup C 84\% (95\% Cl: 77-90\%);

- serogroup W135 91\% (95\% Cl: 84 -95\%);

- serogroup Y 95\% (Cl: 90-98\%).

At 12 months post-vaccination, based on GMTs, and/or the percentage of vaccinees with a titre of $>=1: 4$ and/or 1:8, the immune response had remained unchanged for serogroup W135, decreased somewhat for serogroups $C$ and $Y$, but had fallen substantially for serogroup A such that the percentage of adolescents who still had a titre of $>=1: 8$ at 12 months post-vaccination for serogroup A was only $29 \%$ (95\% Cl: 22-38\%). The percentage of adolescents who still had an hSBA titre of $>=1: 8$ at 12 months post vaccination was as follows:

- serogroup C 77\% (95\% Cl: 69-84\%);

- serogroup W135 was 95\% Cl:88-97\%);

- serogroup Y was 82\% (95\% Cl:75-88\%).

One phase III study has been published in adolescents 11-18 years of age. ${ }^{(36)}$ In this US multicenter randomized controlled trial, 2180 adolescents received a single dose of one of three lots of Men-C-ACYW-135-CRM (Menveo ${ }^{\mathrm{TM}}$ ) or a single dose of Men-C-ACYW-135-D (Menactra ${ }^{\mathrm{TM}}$ ). Due to limited human complement, immunogenicity was only assessed in some subjects (between 288 and 501 adolescents for Men-C-ACYW-135-D depending on the serogroup; and between 1024 and 1483 adolescents for Men-C-ACYW-135-CRM depending on the serogroup). The three lots of Men-C-ACYW135-CRM were combined for the analysis as they had similar immunogenicity results. Using GMTs at one month postvaccination, Men-C-ACYW-135-CRM was determined to be superior to Men-C-ACYW-135-D for all serogroups. Using an hSBA titre of $>=1: 8$ at one month post-vaccination, Men-C-ACYW-135-CRM was superior to Men-C-ACYW-135-D for all serogroups except serogroup C, where Men-C-ACYW135-CRM was non-inferior to Men-C-ACYW-135-D. The greatest difference in percentage of adolescents achieving an hSBA titre of $>=1: 8$ was found for serogroup Y: $88 \%$ for Men-C-ACYW-135-CRM (95\% Cl: 85-90\%) versus 69\% for Men-C-ACYW-135-D (95\% Cl: 63-74\%). The clinical significance of the differences in immune responses between the two products is uncertain, particularly with respect to duration of protection.

The percentage of adolescents achieving a hSBA titre $>=1: 8$ one month post-vaccination with Men-C-ACYW-135-CRM (Menveo ${ }^{\mathrm{TM}}$ ) was as follows:

- serogroup A 75\% (95\% Cl: 73-78\%);

- serogroup C 84\% (95\% Cl: 82-86\%);

- serogroup W135 96\% (95\% Cl: 95-97\%);

- serogroup Y $88 \%$ (95\% Cl: 85-90\%).

A study by Gill et al. ${ }^{(37)}$ extends the immunogenicity data on a subset of patients included in the Jackson study described above. ${ }^{(36)}$ Of the original cohort vaccinated between 11-18 years of age, 278 of those who received Men-C-ACYW-135-CRM (Menveo ${ }^{\mathrm{TM}}$ ) and 191 of those who received Men-C-ACYW-135-D 
(Menactra ${ }^{\mathrm{TM}}$ ) were assessed a median of 22 months post-vaccination. The immunological response was compared to 128 controls who had not been previously vaccinated.

The percentage of subjects who achieved an hSBA titre $>=1: 8$ was significantly higher for those who received Men-C-ACYW135-CRM compared to Men-C-ACYW-135-D for serogroups A, W135 and $Y$ and non-significantly higher for serogroup $C$. GMTs were also significantly higher for the Men-C-ACYW135-CRM group compared to Men-C-ACYW-135-D for serogroups $A$ and $Y$ and non-significantly higher for serogroups $C$ and W135. It is hypothesized that the higher rates of persistence of the immune response for Men-C-ACYW-135-CRM are related to the higher GMTs that were achieved one month post-vaccination. For the Men-C-ACYW-135-CRM group, the percentage who had a hSBA titre of $>=1: 8$ at a median of 22 months post-vaccination were as follows:

- serogroup A 36\%;

- serogroup C 62\%;

- serogroup W135 84\%;

- serogroup Y $67 \%$.

\section{IV.5.4 Adults}

Men-C-ACYW-135-CRM (Menveo ${ }^{\mathrm{TM}}$ ) has also been studied in adults aged 19-55 years of age by Reisinger et al. ${ }^{(38)}$ using similar methodology to the phase III adolescent study by Jackson described above. ${ }^{(36)}$ A total of 1359 adults were randomized to receive one of three lots of Men-C-ACYW135-CRM (Menveo ${ }^{\mathrm{TM}}$ ) or Men-C-ACYW-135-D (Menactra ${ }^{\mathrm{TM}}$ ). Based on results of the adolescent trial where the three lots of Men-C-ACYW-135-CRM gave consistent results, the three lots were combined for this analysis.

Based on the proportion of adults who achieved a titre of $>=1: 8$ at one month post-vaccination, Men-C-ACYW-135-CRM (Menveo $^{\mathrm{TM}}$ ) was non-inferior to Men-C-ACYW-135-D (MenactraTM) for all four serogroups and superior for serogroups $C$ and $Y$. Based on GMTsatone month post-vaccination, Men-C-ACYW135-CRM was non-inferior to Men-C-ACYW-135-D for all four serogroups and superior for serogroups C, W135 and Y. Further study is required to determine if these findings translate to superior clinical protection from invasive meningococcal disease and the impact on duration of protection.

The percentage of adults achieving a hSBA titre $>=1: 8$ at one month post-vaccination with Men-C-ACYW-135-CRM (Menveo ${ }^{\mathrm{TM}}$ ) was as follows:

- serogroup A 69\% (95\% Cl: 66-72\%);

- serogroup C 80\% (95\% Cl: 77-83\%);
- serogroup W135 94\% (95\% Cl: 91-96\%);

- serogroup Y 79\% (Cl: 76-83\%).

Two multicentered, controlled trials by Gill et al. ${ }^{(39)}$ studied the immune response of Men-C-ACYW-135-CRM (Menveo ${ }^{\mathrm{TM}}$ ) in adults. In the19-55 year old age group, 3864 people were enrolled and randomized to receive either Men-C-ACYW135-CRM or Men-C-ACYW-135-D (Menactra ${ }^{\mathrm{TM}}$ ). In the 56-65 year old age group, 326 people were enrolled and randomized to receive either Men-C-ACYW-135-CRM or unconjugated polysaccharide quadrivalent vaccine (Men-P-ACYW-135 Menomune ${ }^{\mathrm{TM}}$ ). Men-C-ACYW-135-CRM was non-inferior to the comparator vaccine for all serogroups and statistically higher for some serogroups. In the 56-65 year olds, Men-CACYW-135-CRM induced geometric mean titres (GMTs) that were 1.4 to 5-fold higher than Men-P-ACYW-135.

\section{IV.5.5 Summary of Immunogenicity Data for Men-C-ACYW-135-CRM (Menveo ${ }^{\mathrm{TM}}$ )}

Thirteen studies of the immunogenicity of Men-C-ACYW135-CRM (Menveo ${ }^{\mathrm{TM}}$ ) with or without the adjuvant were reviewed, some with concomitant administration of other age-appropriate vaccines, involving subjects from 2 months to 65 years of age. These studies are summarized in Table 8.

Men-C-ACYW-135-CRM has been found to be immunogenic in infants and toddlers; however as previously recommended by $\mathrm{NACl}$, infants vaccinated at less than one year of age show a waning immune response indicating the need for a booster dose in the second year of life (from 12 to 23 months of age).

Men-C-ACYW-135-CRM in those 2 to 65 years of age was compared with unconjugated quadrivalent polysaccharide vaccines (Men-P-ACYW-135 - Menomune ${ }^{\mathrm{TM}}$ ), and/or the other available quadrivalent conjugate meningococcal vaccine, Men-C-ACYW-135-D (Menactra ${ }^{\mathrm{TM}}$ ). In every comparison assessing serogroups $C, Y$, and $\mathrm{W} 135$, and in most comparisons assessing serogroup A, Men-C-ACYW-135-CRM was found to be non-inferior to these vaccines and in several instances, Men-C-ACYW-135-CRM was found to have a statistically superior immune response. The implication of the higher immune response on clinical effectiveness, and particularly on duration of protection, is not certain. 


\section{IV.6 SCHEDULE, DOSAGE AND ROUTE OF ADMINISTRATION FOR MEN- C-ACYW-135-CRM (MENVEOTM)}

The dose of Men-C-ACYW-135-CRM (Menveo ${ }^{\mathrm{TM}}$ ) is $0.5 \mathrm{ml}$ intramuscularly (IM). A single dose of Men-C-ACYW-135-CRM (Menveo ${ }^{\mathrm{TM}}$ ) is authorized for use in those 2-55 years of age. See Recommendation section for possible additional uses.

\section{IIV.7 BOOSTER DOSES AND RE-IMMUNIZATION}

Circulating antibodies are considered necessary to protect an individual against invasive meningococcal disease (IMD). Indirect protection (to non-immunized persons) through herd immunity also contributes to decreased frequency of IMD when meningococcal vaccine programs are in place.

$\mathrm{NACl}$ has previously recommended an adolescent dose of conjugate meningococcal vaccine, even if conjugate serogroup $C$ vaccination was previously received as an infant or toddler. The need for further booster doses after adolescence has not yet been determined and will be dependent on the duration of protection achieved by the conjugate meningococcal dose in adolescence and the burden of meningococcal disease in older age groups.

The Advisory Committee on Immunization Practices in the United States has recommended that those previously vaccinated with a quadrivalent meningococcal vaccine at age $\geq 7$ years and who are at prolonged increased risk should be revaccinated 5 years after their previous dose, and persons previously vaccinated at 2-6 years of age and who are at prolonged increased risk should be revaccinated 3 years after their previous dose. ${ }^{(40)}$ In addition, the Advisory Committee on Immunization Practices has recommended a booster dose of quadrivalent vaccine at 16 years of age in those vaccinated routinely with quadrivalent meningococcal vaccine at 11 to 12 years of age, and 2-dose primary series 2 months apart for those 2 to 54 years of age with certain high-risk medical conditions. ${ }^{(13)}$ It should be noted that unlike Canada, the United States does not have an infant or toddler meningococcal vaccine program.

For high risk individuals who remain at ongoing or recurring risk of exposure to meningococcal disease (research, industrial and clinical laboratory personnel who are potentially routinely exposed to N. meningitidis; or travellers or military personnel who remain in or revisit areas where meningococcal vaccine is recommended) or high risk individuals with underlying medical conditions (asplenia; complement, properdin, factor D or primary antibody deficiencies; or HIV), the following re-vaccination schedule is recommended by $\mathrm{NACl}$, based on expert opinion:

- For those vaccinated at 6 years of age and under: provide a booster dose $3-5$ years after the last dose, followed by every 5 years.

- For those vaccinated at 7 years of age and older: provide a booster dose 5 years after the last dose, followed by every 5 years.

- Travellers to Hajj should check recommendations for re-vaccination at: http://www.hajinformation.com/main/ p3001.htm as more frequent re-vaccination may be required.

A quadrivalent conjugate meningococcal vaccine should be used for re-vaccination and based on expert opinion, either Men-C-ACYW-135- D (MenactraTM) or Men-C-ACYW-135-CRM (Menveo ${ }^{\mathrm{TM}}$ ) can be used, regardless of what meningococcal vaccine was used for the initial vaccination.

For those previously vaccinated who are now close contacts or during outbreaks, revaccination as follows is recommended, based on expert opinion:

- Those previously vaccinated with a serogroup that differs from the index case or outbreak strain should be vaccinated immediately with the appropriate vaccine (as outlined in Recommendation 3 below);

- Those previously vaccinated with a serogroup that is the same as the index case or outbreak strain should be revaccinated with the appropriate vaccine(as outlined in Recommendation 3 below):

- If they were less than 1 year of age at last meningococcal vaccination and more than 4 weeks have passed since their last meningococcal vaccine;

- If they have an underlying medical condition that puts them at risk for meningococcal disease and more than 4 weeks have passed since their last meningococcal vaccine;

- If more than a year has passed since their last meningococcal vaccine if they were not less than 1 year of age at the time of their last meningococcal vaccination and if they have no underlying medical condition that puts them at risk for meningococcal disease.

\section{IV.8 SEROLOGICAL TESTING}

There is no indication for routine pre- or post-immunization serology. 


\section{IV.9 STORAGE REQUIREMENTS FOR MEN-C-ACYW-135-CRM (MENVEOTM)}

Store Menveo ${ }^{\mathrm{TM}}$ in the refrigerator between $2^{\circ} \mathrm{C}$ to $8^{\circ} \mathrm{C}$ and protect from light. Do not freeze Menveo ${ }^{\mathrm{TM}}$ and discard it if it is accidently frozen. Once reconstituted, use Menveo ${ }^{\mathrm{TM}}$ immediately, but it may be held at or below $25^{\circ} \mathrm{C}$ for up to 2 hours.

See the "Men-C-ACYW-135-CRM (Menveo ${ }^{\mathrm{TM}}$ ) description and composition" section above for reconstitution instructions. The liquid conjugate meningococcal C, W135, and $Y$ component may have a different expiry date than the conjugate meningococcal A powder component. The product should not be used beyond the outer carton expiry date.

\section{IV.10 SIMULTANEOUS ADMINISTRATION}

\section{IV.10.1 Men-C-ACYW-135-CRM (Menveo'TM)} Infants enrolled in the Phase II clinical trial reported by Snape et al(28) and Perrett et al(31) received other routine childhood vaccines at the same time as Men-C-ACYW-135-CRM with or without adjuvant. In Canada, infants received the 7-valent conjugate pneumococcal vaccine (Prevnar ${ }^{\circledast}$, Pfizer Vaccines), hepatitis B vaccine (Recombivax ${ }^{\circledR}$, Merck and Co.) and diphtheria, tetanus, polio, acellular pertussis and Haemophilus influenzae type b (Hib) (Pentacel ${ }^{\circledR}$, sanofi pasteur). At 12 months of age they received MMR (MMR $\|{ }^{\circledR}$, Merck and Co.) with the booster dose of Men-C-ACYW-135-CRM. In the UK, infants received diphtheria, tetanus, polio, acellular pertussis and Hib (Pediacel ${ }^{\circledR}$, sanofi pasteur) along with the adjuvanted Men-C-ACYW-135-CRM vaccine. In the Snape et al study, one month after the completion of the primary series for these concomitantly administered vaccines, the immune response was found to be excellent ( $>=90 \%$ achieved the correlate of protection for the concomitantly administered vaccines). In the Canadian arm of the Perrett et al study, only the first two doses of the primary series of Pentace ${ }^{\circledR}$, Prevnar $^{\circledR}$ and Recombivax $^{\circledR}$ ( 2 and 4 month doses) were administered prior to blood testing at 5 months. Nonetheless, very good immune responses were achieved for most concomitantly administered antigens, with exceptions being the response to some pneumococcal serotypes and Hib (where very good response was noted after completion of the three doses of Pediace ${ }^{\circledR}$ at 2, 3 and 4 months in the UK).

A randomized controlled study by Arguedas et al ${ }^{(41)}$ involving 1620 adolescents aged 11-18 years from Costa Rica studied the effect of concomitant administration of Men-C-ACYW135-CRM (Menveo ${ }^{\text {TM}}$ ) with the quadrivalent human papillomavirus vaccine (HPV) (Gardasil ${ }^{\mathrm{TM}}$ - Merck \& Co.) and a tetanus, diphtheria and acellular pertussis (Tdap) (Boostrix ${ }^{\circledR}$ GlaxoSmithKline) vaccine. Other groups were given Men-C-ACYW-135-CRM alone one month before Tdap or were given Men-C-ACYW-135-CRM one month after Tdap. Immune response was measured one month post-vaccination.

Concomitant administration resulted in similar rates of local reactions when the three vaccines were given at the same visit or when Men-C-ACYW-135-CRM was given one month before or after Tdap; The reported rates of systemic reactions when Men-C-ACYW-135-CRM was administered concomitantly was $58 \%$, when given alone was $51 \%$ or when given after Tdap was $43 \%$. No serious adverse events were considered to be possibly or probably related to the Men-C-ACYW-135-CRM vaccine.

The immunogenicity of HPV 6, 11, 16 and 18; meningococcal A, $\mathrm{C}$, and $\mathrm{Y}$; and diphtheria and tetanus were similar regardless of the schedule of administration, although higher geometric mean concentrations were achieved for diphtheria when administered concomitantly with Men-C-ACYW-135-CRM and HPV compared to other schedules. The pertussis toxoid, filamentous hemagglutinin, and pertactin had statistically significantly higher responses as measured by geometric mean concentrations when Tdap was given one month after Men-C-ACYW-135-CRM than when Tdap was given alone. When Tdap was administered concomitantly with Men-CACYW-135-CRM and HPV, the geometric mean concentration for the filamentous hemagglutinin and pertactin antigens were statistically significantly lower compared to the group that received Tdap alone. The clinical relevance of this is uncertain. Using the percentage of recipients who achieved an hSBA titre of $>=1: 8$, all schedules resulted in a similar immune response for meningococcal serogroups; however, using seroresponse as a measure of immunity, the response to meningococcal W135 was lower when Men-C-ACYW135-CRM was given one month after Tdap than when the two vaccines were given concomitantly or when Men-C-ACYW135-CRM was given alone. The clinical relevance of these findings is uncertain.

Similar results were found in a study by Gasparini et al. ${ }^{(42)}$ in which 1072 adolescents and young adults aged $11-25$ years were randomized to one of three groups:

- Group 1 - Men-C-ACYW-135-CRM (Menveo ${ }^{\mathrm{TM}}$ ) and Tdap (Boosterix ${ }^{\oplus}$ - GlaxoSmithKline) administered concomitantly;

- Group 2 - Tdap administered with placebo; and

- Group 3 - Men-C-ACYW-135-CRM administered with placebo. 
There were no clinically significant adverse events related to any vaccine. In general, local and systemic reactions were reported more frequently in the group that received Tdap and Men-C-ACYW-135-CRM concomitantly and in the Tdap alone group, compared to the Men-C-ACYW-135-CRM group.

Significantly higher responses to diphtheria were found in the concomitant group. The response to two pertussis antigens (pertussis toxoid, and pertactin) was slightly lower in the concomitant group compared to when Tdap was administered alone. The response to tetanus toxoid and the meningococcal serogroups were unaffected by co-administration.

\section{IV.10.2 Men-C-ACYW-135-D (MenactraT ${ }^{\mathrm{TM}}$ )} In an open labelled, multicentered, randomized controlled study by Reisinger et al. ${ }^{(43)} 394$ boys and 648 girls who were between the ages of 10 and 17 years were randomized to one of two groups.

- Group A received the quadrivalent human papillomavirus vaccine (Gardasil ${ }^{\circledR}$ - Merck and Co., Inc) on day 1 and at months 2 and 6; Men-C-ACYW-135-D (Menactra ${ }^{\mathrm{TM}}$ ) and diphtheria, tetanus, and acellular pertussis (Tdap - Adacel ${ }^{\mathrm{TM}}$ - sanofi pasteur) were also received on day 1.

- Group B received the human papillomavirus vaccine on day 1, and at months 2 and 6; Men-C-ACYW-135-D and Tdap were received at month 1 .

On day 1 in Group A, the human papillomavirus vaccine was given in one arm and Men-C-ACYW-135-D and Tdap were both given in the opposite arm. At month 1 in Group B, the Men-C-ACYW-135-D and Tdap were both given in the same arm using the arm opposite to the day 1 human papillomavirus vaccine. Blood was drawn from Group A on day 1 and at months 1 and 7, and from Group B on day 1 and at months 1, 2 and 7.

There were no safety concerns with concomitant administration of all three vaccines, with no serious adverse events reported after concomitant administration. The only statistically significant differences noted in the study were more swelling in the human papillomavirus vaccine arm on day 1 when all three vaccines were administered concomitantly (Group A) (10.9\%) compared to when human papillomavirus vaccine was given alone (Group B) (6.9\%), and in the Men-C-ACYW-135-D and Tdap arm where there was more pain in Group A versus Group B (81.9\% versus $75.6 \%$ ) and more bruising in Group A versus Group B (5.8\% versus 2.2\%).

The immune response in Group A was non-inferior to the immune response in Group B for all antigens. It should be noted that Group B received Men-C-ACYW-135-D and Tdap on the same day, so no comparison can be made regarding the immune response to each of these vaccines given alone.

\section{IV.10.3 13-valent pneumococcal conjugate vaccine and $\mathrm{CRM}_{197}$-containing meningococcal conjugate vaccines}

A study by Diez-Domingo et al. ${ }^{(44)}$ found a reduction in immunity to meningococcal $C$ when the 13-valent pneumococcal CRM $_{197}$ -conjugate vaccine was co-administered with a $\mathrm{CRM}_{197}{ }^{-}$ containing monovalent meningococcal $\mathrm{C}$ conjugate vaccine, compared to when the 7-valent pneumococcal conjugate vaccine was co-administered with the same meningococcal $\mathrm{C}$ conjugate vaccine. The study enrolled 6212 -month old infants in Spain. The vaccination schedule was as follows: conjugate pneumococcal and meningococcal $\mathrm{C}$ vaccines at 2 and 4 months of age; pneumococcal vaccine alone at 6 months of age, and pneumococcal and meningococcal $C$ vaccines at 15 months of age. The infants were randomized to receive either the 7-valent or 13-valent conjugate pneumococcal vaccine. Other routine vaccines were administered concomitantly. At 5 months of age, the GMTs for meningococcal C were lower in the group who received the 13-valent pneumococcal vaccine compared to the 7 -valent vaccine $(191(95 \% \mathrm{Cl}$ : 168-218) compared to 266 (95\% Cl: 235-302), respectively). The difference in GMTs was more marked at 16 months of age when the GMT for meningococcal C was 432 (95\% Cl: $361-517)$ in the group that received the 13-valent pneumococcal vaccine compared to 731 (95\% Cl: 642-832) in the group that received the 7-valent pneumococcal vaccine; however, the proportion of responders was $>97 \%$ in both groups. It is possible that the larger amount of $\mathrm{CRM}_{197}$ in the 13-valent pneumococcal vaccine is interfering with the response to the $\mathrm{CRM}_{197}$-containing meningococcal $\mathrm{C}$ vaccine. ${ }^{(45)}$ The clinical significance of this as it relates to meningococcal C CRM -conjugate vaccines or Men-C-ACYW-135-CRM (Menveo ${ }^{\mathrm{TM}}$ ) co-administered with the 13-valent conjugate pneumococcal vaccine is unknown. Additional studies of co-administration of these vaccines are required.

\section{IV.11 VACCINE SAFETY AND ADVERSE EVENTS}

\section{IV.11.1 Men-C-ACYW-135-CRM (Menveo'TM)}

Eleven studies of the safety and reactogenicity of Men-C-ACYW135-CRM with or without the adjuvant were reviewed, some with concomitant administration of other vaccines. The safety and adverse events data are summarized in Table 8. No significant safety concerns have been raised with the use of 
Men-C-ACYW-135-CRM (Menveo ${ }^{\mathrm{TM}}$ ). In almost all studies, when compared to either the monovalent meningococcal $\mathrm{C}$ conjugate vaccine, the unconjugated quadrivalent polysaccharide vaccine (Men-P-ACYW-135 - Menomune ${ }^{\mathrm{TM}}$ ), or the other available quadrivalent conjugate meningococcal vaccine, Men-C-ACYW-135-D (MenactraTM), the rate of local and systemic adverse events following Men-C-ACYW-135-CRM with or without adjuvant have been similar. In all but one study, no serious adverse events were felt by the investigators to be related to Men-C-ACYW-135-CRM.

In the study using Men-C-ACYW-135-CRM with adjuvant in infants ${ }^{(28)}$, the investigators reported two serious adverse events which were thought to be related to the Men-C-ACYW-135CRM: thrombocytopenic purpura and supraventricular tachycardia. The child with the thrombocytopenic purpura had an antecedent viral infection and the thrombocytopenic purpura resolved spontaneously. The child with the supraventricular tachycardia had a history of recurrent supraventricular tachycardia and was enrolled in violation of the study's exclusion criteria. Based on the information provided, it is possible both of these events could be related to antecedent conditions in the individuals immunized.

No increased risk for Guillain-Barré Syndrome (GBS) has been noted in the clinical trials involving Men-C-ACYW-135-CRM (Menveo ${ }^{\mathrm{TM}}$ ).

\section{IV.11.2 Men-C-ACYW-135-D (Menactra' ${ }^{\mathrm{TM}}$ )}

Based on passive surveillance in the United States, $\mathrm{NACl}$ has previously recommended caution when administering Men-C-ACYW-135-D (MenactraTM) to people with a past history of Guillain-Barré Syndrome (GBS). ${ }^{(3)} \mathrm{NACl}$ now recommends that the Men-C-ACYW-135-D (Menactra' ${ }^{\text {TM}}$ ) can be administered without safety concerns to people with a previous history of GBS as a result of two large US studies of recipients of Menactra ${ }^{\mathrm{TM}}$ described below.

The Meningococcal Vaccine Study was coordinated by the Harvard Pilgram Health Institute. It followed 12,589,910 people aged 11-21 years from five US health plans for a total of $18,322,800$ person-years. A total of 1.4 million doses of Men-C-ACYW-135-D were observed to have been given and 99 cases of GBS were confirmed to have occurred. None of the cases of GBS occurred within 6 weeks of receipt of Men-C-ACYW-135-D.(46) The second study involves the Vaccine Safety Datalink (VSD), a collaborative effort between the Center for Disease Control and Prevention (CDC) and eight large managed care organizations in the United States. Since 2005, the VSD has been monitoring for the occurrence of GBS between 1 and 42 days post-vaccination with
Men-C-ACYW-135-D in adolescents 11-19 years of age. At the time of analysis, 889,684 doses of Men-C-ACYW-135-D had been administered at the eight sites and no verified cases of GBS had been identified within 1 to 42 days of receipt of the vaccine. ${ }^{(47)}$

\section{IV.12 CONTRAINDICATIONS AND PRECAUTIONS FOR MEN-C-ACYW-135-CRM (MENVEO'TM)}

A history of anaphylaxis to a previous dose of meningococcal vaccine, to any vaccine that contains diphtheria toxoid or $\mathrm{CRM}_{197}$, or to any component of Men-C-ACYW-135-CRM (Menveo ${ }^{\mathrm{TM}}$ ) is a contraindication to the use of this product.

Severe acute febrile illness warrants deferring the vaccine until symptoms have resolved.

Conjugate vaccines have not been studied in pregnancy and there are very limited data on the use of Men-C-ACYW135-CRM (Menveo ${ }^{\mathrm{TM}}$ ) in pregnancy; however in specific circumstances in which the benefits outweigh the risks, its use may be considered.

\section{IV.13 INTERCHANGEABILITY BETWEEN MENINGOCOCCAL VACCINES}

There are several examples where more than one type of meningococcal vaccine product is administered to the same individual. Men-C-ACYW-135-CRM with and without adjuvant has been used after meningococcal $C$ conjugate vaccines resulting in an excellent booster response to serogroup C. ${ }^{(28)(32)}$ Similarly, Men-C-ACYW-135-D (Menactra ${ }^{\mathrm{TM}}$ ) has been shown to induce an excellent booster response after meningococcal $C$ conjugate vaccination. ${ }^{(48)}$ The unconjugated bivalent (serogroups $\mathrm{A}$ and $\mathrm{C}$ ) or quadrivalent polysaccharide vaccines are often used after conjugate vaccines to simulate exposure to disease and induce a good booster immune response..$^{(19)(21)(23)(28)(31)}$

Therefore, based on expert opinion, if a quadrivalent product is chosen for the adolescent dose of meningococcal vaccine, Men-C-ACYW-135-CRM (Menveo ${ }^{\mathrm{TM}}$ ) or Men-C-ACYW-135-D (Menactra ${ }^{\mathrm{TM}}$ ) may be used, regardless of what meningococcal vaccine was previously used.

There is no data on using Men-C-ACYW-135-CRM (Menveo ${ }^{\mathrm{TM}}$ ) after Men-C-ACYW-135-D (MenactraTM) or vice versa. However, should revaccination with a quadrivalent conjugate product be needed, based on expert opinion, either product may be used following the other. 


\section{Recommendations}

\section{V.1 ADOLESCENTS}

$\mathrm{NACl}$ continues to recommend that all Canadian adolescents receive a dose of meningococcal conjugate vaccine around the age of 12 years, even if previously vaccinated as an infant or toddler. Either a monovalent meningococcal C conjugate or quadrivalent conjugate meningococcal product may be chosen depending on local epidemiology and other programmatic considerations. If a quadrivalent meningococcal conjugate product is chosen, either Men-C-ACYW-135-D (Menactra $^{\text {TM}}$ ) or Men-C-ACYW-135-CRM (Menveo ${ }^{\mathrm{TM}}$ ) may be used.

NACI Recommendation Grade B

\section{V.2 HIGH-RISK GROUPS}

As previously recommended, individuals with the following risk factors should receive quadrivalent conjugate meningococcal vaccine.

- Persons with anatomic or functional asplenia (including sickle cell disease);

- Persons who have complement, properdin, factor D or primary antibody deficiencies;

- Persons with acquired complement deficiency (eg. those receiving eculizumab (Soliris ${ }^{\mathrm{TM}}$ );

- Travellers when meningococcal vaccine is recommended (meningitis belt of Subsaharan Africa) or required (pilgrims to the Hajj in Mecca);

- Research, industrial and clinical laboratory personnel who are routinely exposed to N. meningitidis; and

- Military personnel during recruit training and on certain deployments (Military personnel may be at increased risk when accommodated in close quarters or through deployment to endemic / epidemic countries).

NACl Recommendation Grade B

$\mathrm{NACl}$ has previously stated that the quadrivalent conjugate meningococcal vaccine could be considered for individuals with HIV.

NACl Recommendation Grade B

\section{Age Considerations for the Above-High-Risk Groups:}

In reviewing the following age considerations for the above high risk groups, it should be noted that both Menveo TM and Menactra ${ }^{\mathrm{TM}}$ have been authorized for use in Canada in individuals aged 2-55 years.

\section{AGE LESS THAN 2 YEARS WITH THE ABOVE HIGH-RISK CONDITIONS}

Men-C-ACYW-135-CRM (Menveo ${ }^{\mathrm{TM}}$ ) has been found to be safe and immunogenic in children less than 2 years of age. ${ }^{(28)(31)(32)}$ Men-C-ACYW-135-D (Menactra ${ }^{\text {TM}}$ ) has been found to be only modestly immunogenic in infants, but appears to prime the immune response in the majority of infants given three doses. ${ }^{(49)}$ Based on available published data,Men-C-ACYW-135-CRM (Menveo ${ }^{\mathrm{TM}}$ ) is the recommended product in this age group. Possible schedules for vaccinating high-risk infants and young children based on clinical trials of immunogenicity can be found in Table 12.

\section{AGE 2-10 YEARS WITH THE ABOVE HIGH-RISK CONDITIONS}

Based on expert opinion, either quadrivalent conjugate meningococcal vaccine can be used for children in this group. Two doses at least 8 weeks apart are recommended for those in the high risk group due to underlying medical conditions (asplenia; complement, properdin, factor D or primary antibody deficiencies; or HIV). A minimum 4 week interval can be used if rapid protection is required. If only one dose was previously given, then give another at the earliest opportunity and proceed with booster doses as outlined below based on the interval from the second dose.

For those who only receive one dose of quadrivalent meningococcal vaccine (eg. travellers) routine monovalent meningococcal $\mathrm{C}$ conjugate vaccine should already have been administered to children 2-10 years of age and if not previously given, should also be administered at least one month after the quadrivalent conjugate vaccine to ensure optimal serogroup $\mathrm{C}$ protection. 


\section{1-55 YEARS WITH THE ABOVE} HIGH-RISK CONDITIONS

Based on expert opinion, either quadrivalent conjugate meningococcal vaccine can be used for individuals in this group. Two doses at least 8 weeks apart are recommended for those in the high risk group due to underlying medical conditions (asplenia; complement, properdin, factor D or primary antibody deficiencies; or HIV). A minimum 4 week interval can be used if rapid protection is required. If only one dose was previously given, then give another at the earliest opportunity and proceed with booster doses as outlined below based on the interval from the second dose.

\section{AGE 56 YEARS AND OLDER WITH THE ABOVE HIGH-RISK CONDITIONS}

Based on expert opinion, either quadrivalent conjugate meningococcal vaccine may be considered for individuals in this group. Two doses at least 8 weeks apart are recommended for those in the high risk group due to underlying medical conditions (asplenia; complement, properdin, factor $\mathrm{D}$ or primary antibody deficiencies; or HIV). A minimum 4 week interval can be used if rapid protection is required. If only one dose was previously given, then give another at the earliest opportunity and proceed with booster doses as outlined below based on the interval from the second dose.

\section{NACl Recommendation Grade B}

\section{V.3 CLOSE CONTACTS AND OUTBREAKS}

\section{Serogroup $C$}

For close contacts of serogroup C IMD when the contact is 11 years of age or older, and to control outbreaks of serogroup $C$ in those 11 years of age and older, either a monovalent meningococcal $\mathrm{C}$ conjugate vaccine or one of the available quadrivalent conjugate meningococcal vaccines may be used. For close contacts of serogroup $C$ who are less than 11 years of age or to control outbreaks of serogroup $C$ in children less than 11 years of age, a monovalent meningococcal $\mathrm{C}$ conjugate vaccine is recommended as more experience is available with these products.

NACl Recommendation Grade A

\section{Serogroups A, W135 and $Y$}

A quadrivalent conjugate meningococcal vaccine is recommended for close contacts of persons with invasive meningococcal disease (IMD) caused by serogroups $A$, W135 or Y, and for the control of outbreaks caused by these serogroups. Either Men-C-ACYW-135-CRM (Menveo TM) or Men-C-ACYW-135-D (Menactra ${ }^{\mathrm{TM}}$ ) may be used for this purpose in those 2 years of age and over.

$\mathrm{NACl}$ Recommendation Grade A

For children less than 2 years of age who are close contacts of a person with IMD caused by serogroups A, W135 or $\mathrm{Y}$ or for outbreaks caused by these serogroups, Men-C-ACYW135-CRM (Menveo ${ }^{\mathrm{TM}}$ ) should be used. Protection from vaccination post-exposure to IMD should last at least one year as this is the period where increased risk has been noted for household contacts. ${ }^{(50)}$ Possible schedules for vaccinating infants and young children for post-exposure protection against serogroups A, Y or W135 or for management of outbreaks caused by these serogroups are outlined in Table 12. There is no data on the use of Men-C-ACYW-135-CRM (Menveo ${ }^{\mathrm{TM}}$ ) in infants younger than 2 months of age.

\section{NACl Recommendation Grade B}

For those previously vaccinated who are now close contacts or during outbreaks, revaccination as follows is recommended, based on expert opinion:

- Those previously vaccinated with a serogroup that differs from the index case or outbreak strain should be vaccinated immediately with the appropriate vaccine (as outlined above);

- Those previously vaccinated with a serogroup that is the same as the index case or outbreak strain should be revaccinated with the appropriate vaccine (as outlined above):

- If they were less than 1 year of age at last meningococcal vaccination and more than 4 weeks have passed since their last meningococcal vaccine;

- If they have an underlying medical condition that puts them at risk for meningococcal disease and more than 4 weeks have passed since their last meningococcal vaccine;

- If more than a year has passed since their last meningococcal vaccine if they were not less than 1 year of age at the time of their last meningococcal vaccination and if they have no underlying medical condition that puts them at risk for meningococcal disease.

\section{NACl Recommendation Grade B}

See the Canadian Immunization Guide for further details regarding the vaccination of close contacts. 


\section{V.4 REVACCINATION FOR CERTAIN HIGH RISK CIRCUMSTANCES AND HIGH RISK GROUPS}

For high risk individuals who remain at ongoing or recurring risk of exposure to meningococcal disease (research, industrial and clinical laboratory personnel who are potentially routinely exposed to $N$. meningitidis; or travellers or military personnel who remain in or revisit areas where meningococcal vaccine is recommended) or high risk individuals with underlying medical conditions (asplenia; complement, properdin, factor D or primary antibody deficiencies; or HIV), the following re-vaccination schedule is recommended by $\mathrm{NACl}$, based on expert opinion:

- For those vaccinated at 6 years of age and under: provide a booster dose 3-5 years after the last dose, followed by every 5 years.

- For those vaccinated at 7 years of age and older: provide a booster dose 5 years after the last dose, followed by every 5 years.

- Travellers to Hajj should check recommendations for re-vaccination at: http://www.hajinformation.com/main/ p3001.htm as more frequent re-vaccination may be required.

A quadrivalent conjugate meningococcal vaccine should be used for revaccination and based on expert opinion, either Men-C-ACYW-135- D (Menactra ${ }^{\text {TM}}$ ) or Men-C-ACYW-135-CRM (Menveo ${ }^{\mathrm{TM}}$ ) can be used, regardless of what meningococcal vaccine was used for the initial vaccination.

\section{NACl Recommendation Grade B}

See Recommendation 3 above for revaccination recommendations for those previously vaccinated who are now close contacts or during an outbreak.

\section{V.5 SIMULTANEOUS ADMINISTRATION WITH OTHER VACCINES}

Men-C-ACYW-135-D (Menactra ${ }^{\text {TM}}$ ) or Men-C-ACYW-135-CRM (Menveo ${ }^{\mathrm{TM}}$ ) can be administered at the same visit as all ageappropriate adolescent and adult vaccines using a separate needle and syringe and injection site. Co-administration of Men-C-ACYW-135-CRM (Menveo ${ }^{\mathrm{TM}}$ ) and Tdap may result in a lower immune response to the pertussis antigens than when Tdap is given alone; however, the clinical significance of this is unknown. Tdap given one month after Men-C-ACYW135-CRM (Menveo ${ }^{\mathrm{TM}}$ ) induces the strongest immunological response to pertussis antigens.

Studies indicate that Men-C-ACYW-135-CRM (Menveo ${ }^{\text {TM}}$ ) can be administered with all routine paediatric vaccines, however further studies are needed with regard to concomitant administration with 13-valent pneumococcal vaccine due to possible immunological interference with $\mathrm{CRM}_{197}$-containing vaccines. The clinical significance of this as it relates to meningococcal C CRM 197 -conjugate vaccines or Men-CACYW-135-CRM (Menveo ${ }^{\mathrm{TM}}$ ) co-administered with the 13-valent conjugate pneumococcal vaccine is unknown.

NACl Recommendation Grade B

\section{V.6 USE IN PATIENTS WITH PAST HISTORY OF GUILLAIN-BARRÉ SYNDROME GBS)}

Either Men-C-ACYW-135-D (Menactra'M) or Men-C-ACYW135-CRM (Menveo ${ }^{\mathrm{TM}}$ ) can be administered to people with a previous history of GBS without safety concerns.

$\mathrm{NACl}$ Recommendation Grade A

\section{Research priorities}

Research to address the following outstanding questions is encouraged

1. The effectiveness and duration of immunogenicity and protection of Men-C-ACYW-135-CRM (Menveo ${ }^{\text {TM}}$ ) and Men-C-ACYW-135-D (Menactra ${ }^{\mathrm{TM}}$ );

2. Further data on the use of Men-C-ACYW-135-CRM (Menveo ${ }^{\mathrm{TM}}$ ) and Men-C-ACYW-135-D (Menactra ${ }^{\mathrm{TM}}$ ) in infants and toddlers;

3. The safety, immunogenicity and effectiveness of Men-C-ACYW-135-CRM (Menveo ${ }^{\text {TM}}$ ) and Men-C-ACYW-135-D (Menactra ${ }^{\mathrm{TM}}$ ) in certain high risk groups such as the immunocompromised;

4. The immunogenicity and safety of Men-C-ACYW-135-CRM (Menveo ${ }^{\mathrm{TM}}$ ) and Men-C-ACYW-135-D (Menactra ${ }^{\mathrm{TM}}$ ) when each is co-administered with age-appropriate vaccines including travel-related vaccines. Studies related to meningococcal $\mathrm{CRM}_{197}$-containing vaccines co-administered with the 13-valent conjugate pneumococcal vaccine are required. 


\section{Surveillance priorities}

Surveillance should also be conducted to address the following outstanding questions:

1. The impact of meningococcal vaccination programs on the epidemiology of invasive meningococcal disease (IMD) in Canada.

2. The coverage rates of Men-C-ACYW-135-CRM (Menveo ${ }^{\mathrm{TM}}$ ) and Men-C-ACYW-135-D (Menactra ${ }^{\mathrm{TM}}$ ) and the impact of these coverage rates on carriage and herd immunity as reflected by IMD in unvaccinated individuals.

\section{List of abbreviations}

$\mathrm{CDC}$

$\mathrm{CRM}_{197}$

DTaP

ELISA

GMC

GMT

GBS

Hib

HPV

hSBA

IG

$\lg G$

IM

IMD

Men-C-ACYW-135-CRM

Men-C-ACYW-135-D

Men-P-ACYW-135

MMR

$\mathrm{NACl}$

PCV-7

PHAC

rSBA

SBA

SO

Tdap

VSD
Center for Disease Control and Prevention

Corynebacterium diphtheriae cross reacting material 197 used to conjugate meningococcal vaccines

Diphtheria, tetanus and acellular pertussis vaccine

Enzyme linked immunosorbent assays

Geometric mean concentration

Geometric mean titre

Guillain-Barré Syndrome

Haemophilus influenzae type b

Human papillomavirus vaccine

Human complement serum bactericidal antibody

Immunoglobulin

Immunoglobulin G

Intramuscularly

Invasive meningococcal disease

Menveo ${ }^{\mathrm{TM}}$ - Produced by Novartis Vaccines

Menactra ${ }^{\mathrm{TM}}$ - Produced by sanofi pasteur

Menomune ${ }^{\mathrm{TM}}$ - Produced by sanofi pasteur

Measles, Mumps, Rubella

National Advisory Committee on Immunization

Pneumococcoal conjugate vaccine 7 valent

Public Health Agency of Canada

Rabbit complement serum bactericidal antibody

Serum bactericidal antibody

Subcutaneously

Tetanus, diphtheria and acellular pertussis vaccine

Vaccine Safety Datalink 


\section{Tables}

TABLE 8: Summary of Evidence (as at December 2009) for NACI Recommendation(s):

\begin{tabular}{|c|c|c|c|c|c|c|}
\hline \multicolumn{7}{|c|}{ EVIDENCE OF IMMUNOGENICITY FOR MEN-C-ACYW-135-CRM } \\
\hline Study & Vaccine & Study Design & Participants & Outcomes & $\begin{array}{l}\text { Level of } \\
\text { Evidence }\end{array}$ & Quality \\
\hline $\begin{array}{l}\text { Snape } \\
\text { et al. } \\
2008^{(28)} \\
\text { Phase II }\end{array}$ & $\begin{array}{l}\text { Men-C-ACYW-135- } \\
\text { CRM with adjuvant } \\
\text { Concomitant with } \\
\text { Pediacel/Pentacel, } \\
\text { Recombivax, Prevnar, } \\
\text { MMR depending on } \\
\text { routine schedules } \\
\text { Compared to } \\
\text { monovalent } \\
\text { meningococcal C } \\
\text { conjugate (Menjugate) } \\
\text { Men-C-ACYW-135- } \\
\text { CRM with adjuvant } \\
\text { used at } 12 \text { months in } \\
\text { UK groups and some } \\
\text { Canadian groups } \\
\text { 1/5 of unconjugated } \\
\text { quadrivalent } \\
\text { polysaccharide } \\
\text { (Menomune) challenge } \\
\text { at } 12 \text { months in some } \\
\text { Canadian groups }\end{array}$ & $\begin{array}{l}\text { Open-label } \\
\text { randomized } \\
\text { controlled trial } \\
\text { UK and } \\
\text { Canada }\end{array}$ & $\begin{array}{l}\mathrm{N}=421 \text { enrolled } \\
\text { and randomized to } \\
\text { various schedules / } \\
\text { products } \\
\text { UK Men-C-ACYW- } \\
\text { 135-CRM with } \\
\text { adjuvant at 2, 3, } 4 \text { or } \\
2,4 \text { months } \\
\text { Canada } \\
\text { Men-C-ACYW-135- } \\
\text { CRM with adjuvant } \\
\text { at 2, 4, } 6 \text { or } 2,4 \\
\text { months } \\
\text { UK } \\
\text { monovalent } \\
\text { meningcoccal C } \\
\text { conjugate at } 2,4 \\
\text { months } \\
\text { 12 month dose in } \\
\text { UK was } \\
\text { Men-C-ACYW-135- } \\
\text { CRM } \\
\text { in some groups in } \\
\text { Canada with } 1 / 5 \\
\text { dose of Menomune }{ }^{T M} \\
\text { or Men-C-ACYW- } \\
\text { 135-CRM or no } \\
\text { challenge }\end{array}$ & $\begin{array}{l}\text { hSBA } \geq 1: 4 \text { used as measure } \\
\text { of immunity } \\
\text { Three dose schedules had better } \\
\text { immune responses than two } \\
\text { dose schedules } \\
\text { Using 2,4,6 month schedule, } \\
\text { high rates of immunity were } \\
\text { achieved one month post } \\
\text { vaccination with Men-C-ACYW- } \\
\text { 135-CRM with adjuvant; which } \\
\text { fell for serogroups A and C } \\
\text { by } 12 \text { months } \\
\text { GMTs were higher for } \\
\text { serogroup C using monovalent } \\
\text { meningococcal C conjugate } \\
\text { Good boosting at } 12 \text { months } \\
\text { was demonstrated } \\
\text { administered antigens } \\
\text { Ligh percentages (>=90\%) of } \\
\text { Lower GMTs for serogroups A, } \\
\text { received primary series with } \\
\text { meningococcal C conjugate } \\
\text { and then only one dose of } \\
\text { Men-C-ACYW-135-CRM at } \\
\text { who received primary series } \\
\text { and } 12 \text {-month b-ACYW-135-CRM with } \\
\text { adjuvant } \\
\text { Honths }\end{array}$ & Level 1 & Good \\
\hline
\end{tabular}




\begin{tabular}{|c|c|c|c|c|c|c|}
\hline \multicolumn{7}{|c|}{ EVIDENCE OF IMMUNOGENICITY FOR MEN-C-ACYW-135-CRM } \\
\hline Study & Vaccine & Study Design & Participants & Outcomes & $\begin{array}{l}\text { Level of } \\
\text { Evidence }\end{array}$ & Quality \\
\hline $\begin{array}{l}\text { Perrett et } \\
\text { al. 2009(31) } \\
\text { Phase II }\end{array}$ & $\begin{array}{l}\text { Men-C-ACYW-135- } \\
\text { CRM without adjuvant } \\
\text { (Menveo'M) } \\
\text { Concomitant with } \\
\text { Pediacel/Pentacel, } \\
\text { Recombivax, Prevnar, } \\
\text { MMR depending on } \\
\text { routine schedules } \\
\text { Men-C-ACYW-135- } \\
\text { CRM used at } 12 \text { months } \\
\text { in UK and some } \\
\text { Canadians } \\
1 / 5 \text { unconjugated } \\
\text { quadrivalent } \\
\text { polysaccharide } \\
\text { (Menomune) } \\
\text { challenge at } 12 \text { months } \\
\text { in some Canadians }\end{array}$ & $\begin{array}{l}\text { Open-label } \\
\text { controlled trial } \\
\text { UK and Canada } \\
\text { Canadians } \\
\text { randomized at } \\
12 \text { months to } \\
\text { Men-C-ACYW- } \\
135-C R M \text { or } \\
1 / 5 \text { dose of } \\
\text { quadrivalent } \\
\text { polysaccharide } \\
\text { vaccine }\end{array}$ & $\begin{array}{l}\mathrm{N}=180 \text { enrolled } \\
\text { Received Men-C- } \\
\text { ACYW-135-CRM at } \\
2,4 \text { months } \\
12 \text { month dose in } \\
\text { UK was Men-C- } \\
\text { ACYW-135-CRM } \\
12 \text { month challenge } \\
\text { in Canada with } \\
\text { Men-C-ACYW-135- } \\
\text { CRM or } 1 / 5 \text { dose } \\
\text { of quadrivalent } \\
\text { polysaccharide } \\
\text { vaccine }\end{array}$ & $\begin{array}{l}\text { hSBA } \geq 1: 4 \text { used as measure } \\
\text { of immunity } \\
\text { High rates of immunity were } \\
\text { achieved one month post } \\
\text { vaccinationwithMen-C-ACYW- } \\
\text { 135-CRM which fell for all } \\
\text { serogroups by } 12 \text { months } \\
\text { Good boosting at } 12 \text { months } \\
\text { was demonstrated } \\
\text { High percentages of children } \\
\text { achieved protective titres for } \\
\text { most concomitantly administered } \\
\text { antigens (except Haemophilus } \\
\text { influenza type b and some } \\
\text { pneumococcal serotypes in } \\
\text { Canada) given that only two doses } \\
\text { received at time of blood draw } \\
\text { in Canadian children }\end{array}$ & Level I & Good \\
\hline $\begin{array}{l}\text { Halperin } \\
\text { et al. }{ }^{(32)} \\
\text { Phase II }\end{array}$ & $\begin{array}{l}\text { Men-C-ACYW-135- } \\
\text { CRM (Menveo }{ }^{\mathrm{TM}} \text { ) } \\
\text { Compared to } \\
\text { monvalent } \\
\text { meningococcal C } \\
\text { conjugate (Menjugate) } \\
\text { Concomitant with } \\
\text { Pentacel, Prevnar }\end{array}$ & $\begin{array}{l}\text { Open labelled, } \\
\text { partially } \\
\text { randomized, } \\
\text { controlled } \\
\text { Three centres } \\
\text { in Canada }\end{array}$ & $\begin{array}{l}\mathrm{N}=175 \text { enrolled } \\
\text { to one of three } \\
\text { schedules } \\
\text { Ages } 6-12 \text { months } \\
\text { at enrollment } \\
\text { Three groups: } \\
\text { Men-C-ACYW-135- } \\
\text { CRM at } 6 \text { and } \\
12 \text { months; } \\
\text { Men-C-ACYW-135- } \\
\text { CRM at } 12 \text { months; } \\
\text { Monovalent } \\
\text { meningococcal C } \\
\text { conjugate at } 12 \\
\text { months and Men-C- } \\
\text { ACYW-135-CRM at } \\
18 \text { months }\end{array}$ & $\begin{array}{l}\text { hSBA } \geq 1: 4 \text { used as measure of } \\
\text { immunity } \\
\text { Men-C-ACYW-135-CRM at } \\
6 \text { and } 12 \text { months had the best } \\
\text { immune response for all } \\
\text { serogroups except serogroup C } \\
\text { which was exceeded by the } \\
\text { monovalent meningococcal C } \\
\text { conjugate vaccine at } 12 \text { months } \\
\text { and Men-C-ACYW-135-CRM } \\
\text { at } 18 \text { month schedule } \\
\text { For serogroup C, the } \\
\text { monovalent conjugate C } \\
\text { vaccine and Men-C-ACYW- } \\
135-C R M \text { vaccines had similar } \\
\text { responses at } 12 \text { months } \\
\text { For serogroups A, W135 and Y, } \\
\text { the responses to a single } \\
\text { Men-C-ACYW-135-CRM } \\
12 \text { months or } 18 \text { months were } \\
\text { similar and acceptable although } \\
\text { less than the response achieved } \\
\text { by two doses of Men-C-ACYW- } \\
135-C R M \text { at } 6 \text { and } 12 \text { months }\end{array}$ & $\begin{array}{l}\text { Level } 1 \\
\text { Children at } \\
6 \text { months of age } \\
\text { at study entry } \\
\text { were randomized } \\
\text { to } 2 \text { doses } \\
\text { of Men-C- } \\
\text { ACYW-135- } \\
\text { CRM at } 6 \text { and } \\
12 \text { months or a } \\
\text { single dose at } \\
12 \text { months } \\
\text { Children at } 12 \\
\text { months of age } \\
\text { at study entry } \\
\text { all received } \\
\text { monovalent } \\
\text { meningococcal } \\
\text { C conjugate at } \\
12 \text { months and } \\
\text { Men-C-ACYW- } \\
135-C R M \text { at } \\
18 \text { months }\end{array}$ & Good \\
\hline
\end{tabular}




\begin{tabular}{|c|c|c|c|c|c|c|}
\hline \multicolumn{7}{|c|}{ EVIDENCE OF IMMUNOGENICITY FOR MEN-C-ACYW-135-CRM } \\
\hline Study & Vaccine & Study Design & Participants & Outcomes & $\begin{array}{l}\text { Level of } \\
\text { Evidence }\end{array}$ & Quality \\
\hline $\begin{array}{l}\text { Vesikari T } \\
\text { et al.(33) }\end{array}$ & $\begin{array}{l}\text { Men-C-ACYW-135- } \\
\text { CRM } \\
\text { One dose versus two } \\
\text { Boost with } \\
\text { Men-P-ACYW-135 } \\
\text { polysaccharide } \\
\text { vaccine at } 8 \text { months } \\
\text { post vaccination }\end{array}$ & $\begin{array}{l}\text { Dose finding } \\
\text { study } \\
\text { Allocation of } \\
\text { subjects not } \\
\text { described in } \\
\text { abstract } \\
\text { Conducted in } \\
\text { Finland and } \\
\text { Germany }\end{array}$ & $\begin{array}{l}\mathrm{N}=620 \text { enrolled } \\
\text { Ages } 12-16 \text { months } \\
\text { Received one or } \\
\text { two doses of } \\
\text { various formulations } \\
\text { Quadrivalent } \\
\text { polysaccharide } \\
\text { booster } 8 \text { months } \\
\text { post-vaccination } \\
\text { compared to naïve } \\
\text { controls }\end{array}$ & $\begin{array}{l}\text { hSBA } \geq 1: 4 \text { used as measure of } \\
\text { immunity } \\
\text { Two doses had better immune } \\
\text { response than one with } \\
\text { percentage achieving hBSA } \\
>=1: 449-70 \% \text { for the various } \\
\text { serogroups after one dose } \\
\text { and } 91-96 \% \text { after two doses } \\
\text { Good boosting with } \\
\text { quadrivalent polysaccharide } \\
\text { vaccine } 8 \text { months after first } \\
\text { dose }\end{array}$ & $\begin{array}{l}\text { Not enough } \\
\text { information in } \\
\text { the abstract to } \\
\text { assess }\end{array}$ & $\begin{array}{l}\text { Not } \\
\text { enough } \\
\text { information } \\
\text { in the } \\
\text { abstract } \\
\text { to assess }\end{array}$ \\
\hline $\begin{array}{l}\text { Black } \\
\text { et al. }{ }^{(27)} \\
\text { Phase II }\end{array}$ & $\begin{array}{l}\text { Men-C-ACYW-135- } \\
\text { CRM (Menveo }{ }^{T M} \text { ) } \\
\text { Compared to } \\
\text { unconjugated } \\
\text { quadrivalent } \\
\text { polysaccharide } \\
\text { (Men-P-ACYW-135 } \\
\text { - Menomune) }\end{array}$ & $\begin{array}{l}\text { Single blinded } \\
\text { randomized } \\
\text { trial } \\
\text { Oakland, } \\
\text { California }\end{array}$ & $\begin{array}{l}\mathrm{N}=619 \text { enrolled } \\
\text { to one of the two } \\
\text { vaccines } \\
2-10 \text { year olds } \\
\text { Single dose }\end{array}$ & $\begin{array}{l}\text { hSBA } \geq 1: 4 \text { used as measure } \\
\text { of immunity } \\
\text { Immunity to Men-C-ACYW- } \\
\text { 135-CRM was statistically } \\
\text { superior to Men-P-ACYW-135 } \\
\text { at } 1 \text { and } 12 \text { months after } \\
\text { vaccination for almost every } \\
\text { serogroup using percent } \\
\text { achieving hSBA >=1:4 and } \\
\text { GMTs } \\
\text { For Men-C-ACYW-135-CRM, } \\
\text { high rates of immunity were } \\
\text { achieved one month post } \\
\text { vaccination which fell for } \\
\text { serogroups A and C by } 12 \\
\text { months post-vaccination }\end{array}$ & Level 1 & $\begin{array}{l}\text { Good } \\
\text { - single } \\
\text { centre }\end{array}$ \\
\hline $\begin{array}{l}\text { Halperin } \\
\text { et al. } .^{(30)(34)} \\
\text { Phase III }\end{array}$ & $\begin{array}{l}\text { Men-C-ACYW-135- } \\
\text { CRM (Menveo TM) } \\
\text { compared to } \\
\text { Men-C-ACYW-135-D } \\
\text { (Menactra }{ }^{\text {TM) }} \\
\text { 2-5 year olds received } \\
\text { one dose or two doses } \\
\text { of Men-C-ACYW-135- } \\
\text { CRM or one dose of } \\
\text { Men-C-ACYW-135-D } \\
\text { 6-10 year olds received } \\
\text { one dose of Men-C- } \\
\text { ACYW-135-CRM or } \\
\text { Men-C-ACYW-135-D }\end{array}$ & $\begin{array}{l}\text { Partially } \\
\text { observer } \\
\text { blinded } \\
\text { randomized } \\
\text { trial }\end{array}$ & $\begin{array}{l}\mathrm{N}=2,907 \text { children } \\
2-10 \text { years of age }\end{array}$ & $\begin{array}{l}\text { hSBA } \geq 1 \text { : } 8 \text { used as measure } \\
\text { of immunity } \\
\text { Comparing Men-C-ACYW- } \\
\text { 135-CRM to Men-C-ACYW- } \\
\text { 135-D using percent achieving } \\
\text { hSBA >=1:8, response lower } \\
\text { for serogroup A, non-inferior } \\
\text { for serogroup C and statistically } \\
\text { superior for serogroups W135 } \\
\text { and Y } \\
\text { BasedonGMTs, Men-C-ACYW- } \\
\text { 135-CRM was non-inferior to } \\
\text { Men-C-ACYW-135-D for } \\
\text { serogroup A and statistically } \\
\text { superior for serogroups C, W135 } \\
\text { and Y } \\
\text { For } 2-5 \text { year olds, } 2 \text { doses } \\
\text { of Men-C-ACYW-135-CRM } \\
\text { given } 60 \text { days apart had a } \\
\text { better immune response than } \\
\text { one dose }\end{array}$ & Level 1 & Good \\
\hline
\end{tabular}




\begin{tabular}{|c|c|c|c|c|c|c|}
\hline \multicolumn{7}{|c|}{ EVIDENCE OF IMMUNOGENICITY FOR MEN-C-ACYW-135-CRM } \\
\hline Study & Vaccine & Study Design & Participants & Outcomes & $\begin{array}{l}\text { Level of } \\
\text { Evidence }\end{array}$ & Quality \\
\hline $\begin{array}{l}\text { Jackson } \\
\text { et al. } 2009 \\
\text { Phase } \text { II }^{(35)}\end{array}$ & $\begin{array}{l}\text { Men-C-ACYW-135- } \\
\text { CRM with adjuvant } \\
\text { Men-C-ACYW-135- } \\
\text { CRM without adjuvant } \\
\text { (Menveo }^{\text {TM}} \text { ) } \\
\text { Compared to } \\
\text { unconjugated } \\
\text { quadrivalent } \\
\text { polysaccharide } \\
\text { (Men-P-ACYW-135 } \\
\text { - Menomune) }\end{array}$ & $\begin{array}{l}\text { Single blinded } \\
\text { randomized } \\
\text { controlled trial } \\
3 \text { sites in US }\end{array}$ & $\begin{array}{l}\mathrm{N}=524 \text { enrolled } \\
\text { to one of the three } \\
\text { vaccines } \\
11-17 \text { year olds } \\
\text { Single dose }\end{array}$ & 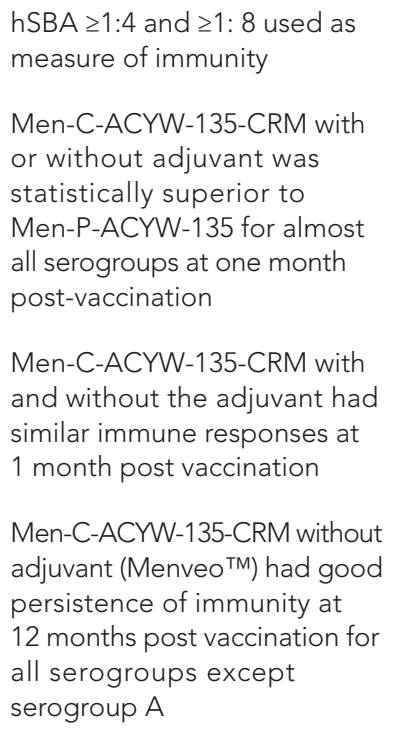 & Level 1 & Good \\
\hline $\begin{array}{l}\text { Jackson } \\
\text { et al. } \\
2009^{(36)} \\
\text { Phase III }\end{array}$ & 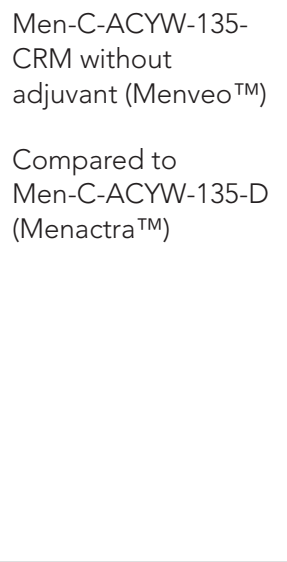 & $\begin{array}{l}\text { Observer } \\
\text { blinded } \\
\text { randomized } \\
\text { controlled trial } \\
44 \text { centers in US }\end{array}$ & $\begin{array}{l}\mathrm{N}=2180 \text { enrolled to } \\
\text { one of two vaccines, } \\
\text { although not all } \\
\text { subjects tested for } \\
\text { all serogroups due } \\
\text { to limited human } \\
\text { complement } \\
\text { 11-18 year olds } \\
\text { Single dose }\end{array}$ & $\begin{array}{l}\text { hSBA } \geq 1: 8 \text { used as measure } \\
\text { of immunity } \\
\text { Based on percentage achieving } \\
\text { hSBA }>=1: 8 \text { at one month } \\
\text { post-vaccination, Men-C- } \\
\text { ACYW-135-CRM superior to } \\
\text { Men-C-ACYW-135-D for all } \\
\text { serogroups except C which } \\
\text { was non-inferior } \\
\text { Based on GMTs at one month } \\
\text { post-vaccination, Men-C- } \\
\text { ACYW-135-CRM superior to } \\
\text { Men-C-ACYW-135-D for all } \\
\text { serogroups }\end{array}$ & Level 1 & Good \\
\hline Gill et al. ${ }^{(37)}$ & $\begin{array}{l}\text { Men-C-ACYW-135- } \\
\text { CRM without } \\
\text { adjuvant (Menveo } \\
\text { Comp) } \\
\text { Men-C-ACYW-135-D } \\
\text { (Menactra }^{\mathrm{TM})} \\
\text { Age-matched } \\
\text { unvaccinated controls }\end{array}$ & $\begin{array}{l}\text { Median of } 22 \\
\text { month } \\
\text { follow-up of a } \\
\text { subset of } \\
\text { subjects from } \\
\text { Jackson's } \\
\text { phase III study } \\
\text { above }^{(36)}\end{array}$ & $\begin{array}{l}278 \text { people } \\
\text { vaccinated at 11-18 } \\
\text { years of age with } \\
\text { Men-C-ACYW-135- } \\
\text { CRM } \\
191 \text { people } \\
\text { vaccinated at 11-18 } \\
\text { years of age with } \\
\text { Men-C-ACYW-135-D } \\
128 \text { unvaccinated } \\
\text { controls }\end{array}$ & $\begin{array}{l}\text { At median of } 22 \text { months post } \\
\text { vaccination, percent hSBA } \geq 1: 8 \\
\text { statistically significantly higher } \\
\text { for Men-C-ACYW-135-CRM } \\
\text { compared to Men-C-ACYW- } \\
\text { 135-D for serogroups A, W135 } \\
\text { and Y and non-statistically } \\
\text { significantly higher for } \\
\text { serogroup C; } \\
\text { GMTs statistically significantly } \\
\text { higher for Men-C-ACYW-135- } \\
\text { CRM compared to Men-C- } \\
\text { ACYW-135-D for serogroups } \\
\text { A and Y and non-statistically } \\
\text { significantly higher for } \\
\text { serogroups C and W-135. }\end{array}$ & Level 1 & Good \\
\hline
\end{tabular}




\begin{tabular}{|c|c|c|c|c|c|c|}
\hline \multicolumn{7}{|c|}{ EVIDENCE OF IMMUNOGENICITY FOR MEN-C-ACYW-135-CRM } \\
\hline Study & Vaccine & Study Design & Participants & Outcomes & $\begin{array}{l}\text { Level of } \\
\text { Evidence }\end{array}$ & Quality \\
\hline $\begin{array}{l}\text { Reisinger } \\
\text { et al. } \\
2009 \\
\text { Phase II|(38) }\end{array}$ & $\begin{array}{l}\text { Men-C-ACYW-135- } \\
\text { CRM without } \\
\text { adjuvant (Menveo }{ }^{\mathrm{TM}} \text { ) } \\
\text { Compared to } \\
\text { Men-C-ACYW-135-D } \\
\text { (Menactra }^{\mathrm{TM}} \text { ) }\end{array}$ & $\begin{array}{l}\text { Randomized } \\
\text { controlled trial } \\
44 \text { centers } \\
\text { in the US }\end{array}$ & $\begin{array}{l}N=1359 \text { enrolled to } \\
\text { one of two vaccines } \\
\text { 19-55 year olds } \\
\text { Single dose }\end{array}$ & $\begin{array}{l}\text { hSBA } \geq 1 \text { : } 8 \text { used as measure } \\
\text { of immunity } \\
\text { Men-C-ACYW-135-CRM } \\
\text { superior to Men-C-ACYW-135-D } \\
\text { for serogroups C and Y and } \\
\text { non-inferior for W135 and A, } \\
\text { based on percent achieving } \\
\text { hSBA > } 1: 8 \text { at one month } \\
\text { post-vaccination } \\
\text { Based on GMTs at one month } \\
\text { post-vaccination, Men-C- } \\
\text { ACYW-135-CRM superior to } \\
\text { Men-C-ACYW-135-D for all } \\
\text { serogroups except serogroup } \\
\text { A where Men-C-ACYW-135- } \\
\text { CRM was non-inferior. }\end{array}$ & Level 1 & Good \\
\hline $\begin{array}{l}\text { Gill CJ } \\
\text { et al }{ }^{(39)}\end{array}$ & $\begin{array}{l}\text { Men-C-ACYW-135- } \\
\text { CRM without adjuvant } \\
\text { (Menveo }^{\mathrm{TM}} \text { ) } \\
\text { in 19-65 year olds } \\
\text { Compared to } \\
\text { Men-C-ACYW-135-D } \\
\text { (Menactra }{ }^{\mathrm{TM}} \text { ) } \\
\text { in 19-55 year olds } \\
\text { Compared to } \\
\text { unconjugated } \\
\text { quadrivalent } \\
\text { polysaccharide } \\
\text { (Men-P-ACYW-135 } \\
\text { - Menomune) } \\
\text { in 56-65 year olds }\end{array}$ & $\begin{array}{l}\text { Two } \\
\text { multcentered, } \\
\text { observer-blinded } \\
\text { randomized } \\
\text { controlled trials } \\
\text { Conducted in } \\
\text { the US and } \\
\text { Latin America }\end{array}$ & $\begin{array}{l}\mathrm{N}=386419-55 \text { year } \\
\text { olds and } 32656-65 \\
\text { year olds }\end{array}$ & $\begin{array}{l}\text { Men-C-ACYW-135-CRM } \\
\text { non-inferior to both } \\
\text { comparator vaccines for all } \\
\text { serogroups using primary } \\
\text { endpoints and statistically } \\
\text { higher for some serogroups } \\
\text { In the } 56-65 \text { year age group, } \\
\text { GMTs } 1.4 \text { to 5-fold higher for } \\
\text { Men-C-ACYW-135-CRM } \\
\text { compared to Men-P-ACYW-135 }\end{array}$ & Level 1 & $\begin{array}{l}\text { Good } \\
\text { Poster } \\
\text { only so } \\
\text { difficult to } \\
\text { assess full } \\
\text { methodol- } \\
\text { ogy }\end{array}$ \\
\hline $\begin{array}{l}\text { Arguedas, } \\
\text { A et al. } \\
\text { Phase } \|^{(41)}\end{array}$ & $\begin{array}{l}\text { Men-C-ACYW-135-CRM } \\
\text { (Menveo }^{\text {TM}} \text { )given with } \\
\text { Tdap and HPV } \\
\text { Compared to } \\
\text { Men-C-ACYW-135- } \\
\text { CRM given one } \\
\text { month before or } \\
\text { after Tdap and HPV } \\
\text { beginning one } \\
\text { month later }\end{array}$ & $\begin{array}{l}\text { Open label } \\
\text { randomized } \\
\text { controlled trial } \\
\text { One center } \\
\text { in Costa Rica }\end{array}$ & $\begin{array}{l}\mathrm{N}=1620 \text { enrolled to } \\
\text { one of three groups } \\
11-18 \mathrm{yr} \text { olds }\end{array}$ & $\begin{array}{l}\text { Seroresponse to serogroup } \\
\text { W135 and Y were lower at one } \\
\text { month post-vaccination if } \\
\text { Men-C-ACYW-135-CRM given } \\
\text { one month after Tdap but } \\
\text { percent acheiving hSBA >=1:8 } \\
\text { comparable } \\
\text { Filamentous hemagluttin and } \\
\text { pertactin had lower responses } \\
\text { if given concomittently than if } \\
\text { Tdap given alone } \\
\text { Highest seroresponses for } \\
\text { pertussis antigens if Tdap } \\
\text { given one month after } \\
\text { Men-C-ACYW-135-CRM }\end{array}$ & Level 1 & Good \\
\hline $\begin{array}{l}\text { Gasparini } \\
\text { et al }\left.\right|^{(42)}\end{array}$ & $\begin{array}{l}\text { Men-C-ACYW-135- } \\
\text { CRM (Menveo }{ }^{\mathrm{TM}} \text { ) } \\
\text { given with Tdap } \\
\text { Compared to Men-C- } \\
\text { ACYW-135-CRM given } \\
\text { alone with a placebo, } \\
\text { and Tdap given alone } \\
\text { with a placebo }\end{array}$ & $\begin{array}{l}\text { Observer- } \\
\text { blinded, } \\
\text { randomized } \\
\text { controlled, study } \\
\text { Multicenter trial }\end{array}$ & $\begin{array}{l}\mathrm{N}=1072 \text { enrolled in } \\
\text { one of three groups } \\
11-25 \text { year olds }\end{array}$ & $\begin{array}{l}\text { Pertussis toxoid, filamentous } \\
\text { hemagluttin and pertactin } \\
\text { had slightly lower responses if } \\
\text { given concomittently with } \\
\text { Men-C-ACYW-135-CRM than } \\
\text { if Tdap given alone }\end{array}$ & Level 1 & Good \\
\hline
\end{tabular}




\begin{tabular}{|c|c|c|c|c|c|c|}
\hline \multicolumn{7}{|c|}{ EVIDENCE OF IMMUNOGENICITY FOR MEN-C-ACYW-135-D ADMINISTERED WITH TDAP AND HPV VACCINES } \\
\hline Study & Vaccine & Study Design & Participants & Outcomes & $\begin{array}{l}\text { Level of } \\
\text { Evidence }\end{array}$ & Quality \\
\hline $\begin{array}{l}\text { Reisinger } \\
\text { KS et al(43) } \\
2009\end{array}$ & $\begin{array}{l}\text { Men-C-ACYW-135-D } \\
\text { with human } \\
\text { papillomavirus } \\
\text { vaccine and Tdap } \\
\text { administered } \\
\text { concomitantly } \\
\text { Compared to human } \\
\text { papillomavirus vaccine } \\
\text { given alone and } \\
\text { Men-C-ACYW-135-D } \\
\text { and Tdap given } \\
\text { together }\end{array}$ & $\begin{array}{l}\text { Open-label } \\
\text { randomized } \\
\text { controlled trial } \\
21 \text { sites } \\
\text { in the US }\end{array}$ & $\begin{array}{l}\mathrm{N}=394 \text { girls and } \\
648 \text { boys randomized } \\
\text { to two groups } \\
10-17 \text { years old } \\
\text { Group A received the } \\
\text { HPV vaccine on day } \\
1 \text { and at month } 2 \text { and } \\
6 \text { and Men-C-ACYW- } \\
135-D \text { and Tdap on } \\
\text { day } 1 \text {; and Group B } \\
\text { received the HPV on } \\
\text { day } 1 \text {, and at month } \\
2 \text { and } 6 \text { and Men-C- } \\
\text { ACYW-135-D and } \\
\text { Tdap at month } 1\end{array}$ & $\begin{array}{l}\text { SBA levels for meningococcal } \\
\text { serogroups (not indicated if } \\
\text { human or rabbit complement) } \\
\text { Non-inferiority for all antigens } \\
\text { in concomitant group where } \\
\text { all three vaccines given on the } \\
\text { same day compared to HPV } \\
\text { given alone and Men-C-ACYV- } \\
\text { 135-D and Tdap given on the } \\
\text { same day one month after } \\
\text { first HPV }\end{array}$ & Level 1 & $\begin{array}{l}\text { Fair } \\
\text {-Comparison } \\
\text { involved } \\
\text { Men-C-ACYW- } \\
\text { 135-D and } \\
\text { Tdap given } \\
\text { together } \\
\text { instead of } \\
\text { each vaccine } \\
\text { alone }\end{array}$ \\
\hline
\end{tabular}

\begin{tabular}{|c|c|c|c|c|c|c|}
\hline \multicolumn{7}{|c|}{$\begin{array}{l}\text { EVIDENCE FOR IMMUNOGENICITY WHEN CRM }{ }_{197} \text { - CONTAINING MENINGOCOCCAL CONJUGATE VACCINE } \\
\text { ADMINISTERED WITH 13-VALENT PNEUMOCOCCAL VACCINE }\end{array}$} \\
\hline Study & Vaccine & Study Design & Participants & Outcomes & $\begin{array}{l}\text { Level of } \\
\text { Evidence }\end{array}$ & Quality \\
\hline $\begin{array}{l}\text { Domingo- } \\
\text { Diez et } \\
\text { al. }{ }^{(44)} \\
2009\end{array}$ & $\begin{array}{l}\text { Monovalent } \\
\text { meningococcal C } \\
\text { CRM }_{197} \text {-containing } \\
\text { conjugate vaccine } \\
\text { administered } \\
\text { concomitantly with } \\
\text { either 13-valent or } \\
\text { 7-valent pneumococcal } \\
\text { vaccines and other } \\
\text { routine childhood } \\
\text { immunizations }\end{array}$ & $\begin{array}{l}\text { Randomized } \\
\text { controlled trial } \\
35 \text { sites in Spain }\end{array}$ & $\begin{array}{l}\mathrm{N}=621 \text { infants } \\
\text { enrolled at } 2 \\
\text { months of age } \\
\text { Meningococcal C } \\
\text { and pneumococcal } \\
\text { vaccines (either } \\
13 \text {-valent or } 7 \text {-valent) } \\
\text { given at } 2 \text { and } \\
4 \text { months; } \\
\text { pneumococcal } \\
\text { vaccine given at } \\
6 \text { months; } \\
\text { meningococcal C } \\
\text { and pneumococcal } \\
\text { vaccine given at } \\
15 \text { months }\end{array}$ & $\begin{array}{l}\text { SBA levels (not indicated if } \\
\text { human or rabbit complement) } \\
\text { GMTs to meningococcal C were } \\
\text { lower in the group that received } \\
\text { the } 13 \text {-valent pneumococcal } \\
\text { vaccine compared to the group } \\
\text { that received the } 7 \text { valent } \\
\text { vaccine; the difference was most } \\
\text { marked at } 16 \text {-months of age } \\
\text { however the percent responders } \\
\text { was }>97 \% \text { in both groups }\end{array}$ & Level 1 & $\begin{array}{l}\text { Good } \\
\text { - poster }\end{array}$ \\
\hline
\end{tabular}

EVIDENCE FOR SAFETY OF MEN-C-ACYW-135-CRM

\begin{tabular}{l|l|l|l|l|l}
\hline Study & Vaccine & Study Design & Participants & Outcomes & $\begin{array}{l}\text { Level of } \\
\text { Evidence }\end{array}$ \\
\hline $\begin{array}{l}\text { Snape et } \\
\text { al. 2008(28) }\end{array}$ & See above & See Above & See Above \\
Men-C-ACYW-135- & $\begin{array}{l}\text { Parents recorded local and } \\
\text { systemic reactions in week } \\
\text { after each vaccine dose }\end{array}$ & $\begin{array}{l}\text { Rates of local and systemic } \\
\text { reactions after Men-C-ACYW- } \\
\text { 135-CRM with adjuvant similar to } \\
\text { monovalent meningococcal C } \\
\text { conjugate (Menjugate) } \\
\begin{array}{l}\text { Pediacel/Pentacel, } \\
\text { Recombivax, Prevnar, } \\
\text { MMR depending on } \\
\text { routine schedules }\end{array}\end{array}$ & $\begin{array}{l}\text { Phone calls to parents in } \\
\text { the week after vaccination, } \\
\text { monthly between infant } \\
\text { and toddler doses and } \\
\text { bonths after final study } \\
\text { immunization }\end{array}$ & $\begin{array}{l}\text { Two serious adverse events } \\
\text { thought to be possibly related } \\
\text { to Men-C-ACYW-135-CRM } \\
\text { with adjuvant: idiopathic } \\
\text { thrombocytopenia purpura and } \\
\text { supraventricular tachycardia }\end{array}$ & Good \\
\hline
\end{tabular}




\begin{tabular}{|c|c|c|c|c|c|c|}
\hline \multicolumn{7}{|c|}{ EVIDENCE FOR SAFETY OF MEN-C-ACYW-135-CRM } \\
\hline Study & Vaccine & Study Design & Participants & Outcomes & $\begin{array}{l}\text { Level of } \\
\text { Evidence }\end{array}$ & Quality \\
\hline $\begin{array}{l}\text { Perrett et } \\
\text { al. 2009(31) }\end{array}$ & $\begin{array}{l}\text { See above } \\
\text { Men-C-ACYW-135- } \\
\text { CRM without adjuvant } \\
\text { Concomitant with } \\
\text { Pediacel/Pentacel, } \\
\text { Recombivax, Prevnar, } \\
\text { MMR depending on } \\
\text { routine schedules }\end{array}$ & $\begin{array}{l}\text { See Above } \\
\text { Parents recorded local and } \\
\text { systemic reactions and } \\
\text { medication use in } 7 \text { days } \\
\text { after each vaccine dose } \\
\text { Parents reported any } \\
\text { physician visit and serious } \\
\text { adverse events } \\
\text { Phone calls to parents after } \\
\text { vaccination, monthly } \\
\text { between infant and toddler } \\
\text { doses and } 5 \text { months after } \\
\text { final study visit }\end{array}$ & See above & $\begin{array}{l}\text { Grade } 3 \text { tenderness at injection } \\
\text { site in } 2-4 \% \text { after at least one } \\
\text { infant dose and 0-1\% after } \\
12 \text { month booster of } \\
\text { Men-C-ACYW-135-CRM } \\
\text { without adjuvant } \\
\text { No serious adverse events } \\
\text { attributed to vaccine }\end{array}$ & Level 1 & Good \\
\hline $\begin{array}{l}\text { Halperin } \\
\text { et al. }{ }^{(32)} \\
\text { Phase II }\end{array}$ & $\begin{array}{l}\text { Men-C-ACYW-135- } \\
\text { CRM without } \\
\text { adjuvant } \\
\text { Compared to } \\
\text { monovalent } \\
\text { meningococcal C } \\
\text { conjugate } \\
\text { (Menjugate) } \\
\text { Concomitant with } \\
\text { Pentacel, Prevnar }\end{array}$ & $\begin{array}{l}\text { See above } \\
\text { Parents recorded local and } \\
\text { systemic reactions for } 7 \text { days } \\
\text { after each vaccine dose } \\
\text { Hospitalizations and other } \\
\text { serious adverse events } \\
\text { collected at any time } \\
\text { during study }\end{array}$ & See above & $\begin{array}{l}\text { No clear difference in frequency } \\
\text { of adverse events between } \\
\text { monovalent meningococcal C } \\
\text { conjugate vaccine and } \\
\text { Men-C-ACYW-135-CRM } \\
\text { No serious adverse events } \\
\text { determined to be } \\
\text { vaccine-related }\end{array}$ & Level 1 & Good \\
\hline $\begin{array}{l}\text { Black } \\
\text { et al. }{ }^{(27)} \\
\text { Phase II }\end{array}$ & $\begin{array}{l}\text { Men-C-ACYW-135- } \\
\text { CRM (Menveo }{ }^{\text {TM}} \text { ) } \\
\text { Compared to } \\
\text { unconjugated } \\
\text { quadrivalent } \\
\text { polysaccharide } \\
\text { (Men-P-ACYW-135 } \\
\text { - Menomune) }\end{array}$ & $\begin{array}{l}\text { See above } \\
\text { Parents recorded local and } \\
\text { systemic reactions between } \\
\text { days } 1 \text { and } 7 \text { after vaccination } \\
\text { Investigators recorded } \\
\text { adverse events requiring } \\
\text { medical attention within } \\
1 \text { month after vaccination } \\
\text { and medically significant } \\
\text { events up to } 12 \text { months } \\
\text { post-vaccination }\end{array}$ & See above & $\begin{array}{l}\text { Statistically significantly more } \\
\text { local and systemic reactions } \\
\text { noted with Men-C-ACYW- } \\
\text { 135-CRM compared to } \\
\text { Men-P-ACYW-135 } \\
\text { No serious adverse vaccine } \\
\text { reactions judged to be related } \\
\text { to vaccine }\end{array}$ & Level 1 & $\begin{array}{l}\text { Good } \\
\text { - single } \\
\text { centre }\end{array}$ \\
\hline $\begin{array}{l}\text { Gill CJ } \\
\text { et al. }{ }^{(51)} \\
\text { Halperin } \\
\text { et al. }{ }^{(34)}\end{array}$ & $\begin{array}{l}\text { Men-C-ACYW-135- } \\
\text { CRM (Menveo }{ }^{T M} \text { ) } \\
\text { compared to } \\
\text { Men-C-ACYW-135-D } \\
\text { (Menactra }{ }^{\text {TM}} \text { ) } \\
\text { 2-5 year olds received } \\
\text { one dose or two doses } \\
\text { of Men-C-ACYW-135- } \\
\text { CRM or one dose of } \\
\text { Men-C-ACYW-135-D } \\
\text { 6-10 year olds received } \\
\text { one dose of Men-C- } \\
\text { ACYW-135-CRM or } \\
\text { Men-C-ACYW-135-D }\end{array}$ & $\begin{array}{l}\text { Recorded all adverse } \\
\text { events for } 7 \text { days post } \\
\text { vaccination }\end{array}$ & $\begin{array}{l}\text { See above } \\
\text { Halperin et } \\
\text { al Phase III } \\
\text { study involving } \\
\text { 2-10 year } \\
\text { olds above }\end{array}$ & $\begin{array}{l}\text { Percentage of children with } \\
\text { local and systemic reactions } \\
\text { similar between Men-C- } \\
\text { ACYW-135-CRM and } \\
\text { Men-C-ACYW-135-D } \\
\text { No serious adverse events } \\
\text { considered related to } \\
\text { study vaccines }\end{array}$ & Level 1 & Good \\
\hline
\end{tabular}




\begin{tabular}{|c|c|c|c|c|c|c|}
\hline \multicolumn{7}{|c|}{ EVIDENCE FOR SAFETY OF MEN-C-ACYW-135-CRM } \\
\hline Study & Vaccine & Study Design & Participants & Outcomes & $\begin{array}{l}\text { Level of } \\
\text { Evidence }\end{array}$ & Quality \\
\hline $\begin{array}{l}\text { Jackson } \\
\text { et al. } \\
2009 \\
\text { Phase II }\end{array}$ & $\begin{array}{l}\text { Men-C-ACYW-135- } \\
\text { CRM with and } \\
\text { without adjuvant } \\
\text { Compared to } \\
\text { unconjugated } \\
\text { quadrivalent } \\
\text { polysaccharide } \\
\text { (Men-P-ACYW-135 } \\
\text { - Menomune) }\end{array}$ & $\begin{array}{l}\text { See above } \\
\text { Reactogenicity data } \\
\text { collected by recipients for } \\
7 \text { days post-vaccination } \\
\text { Telephone interview } \\
\text { conducted on day } 3 \\
\text { post-vaccination } \\
\text { Serious and medically } \\
\text { significant events recorded } \\
\text { by investigators for } \\
12 \text { months }\end{array}$ & See above & $\begin{array}{l}\text { Using Men-C-ACYW-135-CRM } \\
\text { without adjuvant, nausea only } \\
\text { solicited event statistically } \\
\text { significantly more common } \\
\text { compared to Men-P-ACYW-135 } \\
\text { More unsolicited adverse events } \\
\text { possibly or probably related } \\
\text { to vaccine using Men-C-ACYW- } \\
\text { 135-CRM unadjuvanted } \\
\text { compared to Men-P-ACYW-135 } \\
\text { (6.6\% of recipients versus } 2.6 \% \text { ) } \\
\text { No serious adverse events were } \\
\text { assessed as related to vaccine. }\end{array}$ & Level 1 & Good \\
\hline $\begin{array}{l}\text { Jackson } \\
\text { et al. } \\
2009 \\
\text { Phase II|(36) }\end{array}$ & 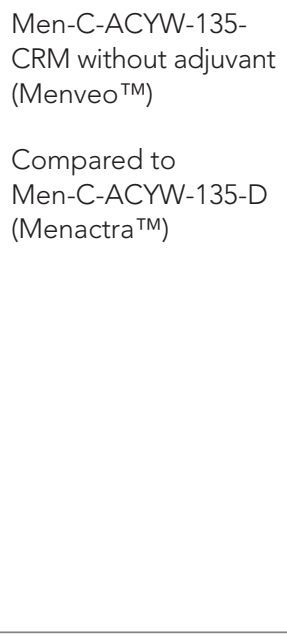 & $\begin{array}{l}\text { See above } \\
\text { Local and systemic side } \\
\text { effects recorded by } \\
\text { recipients for } 7 \text { days post } \\
\text {-vaccination } \\
\text { Reminder telephone calls } \\
\text { on day } 3 \text { post-vaccination } \\
\text { Serious and medically } \\
\text { significant events recorded } \\
\text { by investigators for } 6 \text { months }\end{array}$ & See above & $\begin{array}{l}\text { Local and systemic solicited } \\
\text { adverse events were similar in } \\
\text { the Men-C-ACYW-135-CRM } \\
\text { and Men-C-ACYW-135-D groups } \\
\text { with pain at the injection site } \\
\text { occurring in } 44 \% \text { of Men-C- } \\
\text { ACYW-135-CRM recipients and } \\
53 \% \text { of the Men-C-ACYW-135-D } \\
\text { recipients; most of which } \\
\text { were mild } \\
\text { Similar rates of unsolicited } \\
\text { adverse reactions were reported } \\
\text { between both groups } \\
\text { No serious adverse reactions } \\
\text { were considered to be related } \\
\text { to the study vaccines }\end{array}$ & Level 1 & Good \\
\hline $\begin{array}{l}\text { Reisinger } \\
\mathrm{K}_{1}^{(38)} \text { et al. } \\
2008\end{array}$ & 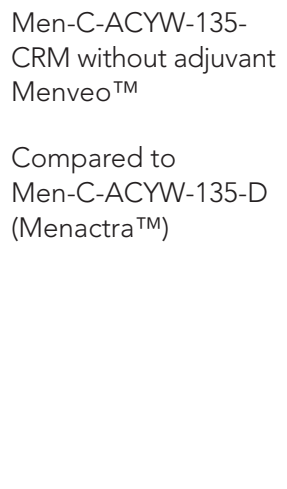 & $\begin{array}{l}\text { See above } \\
\text { Local and systemic side } \\
\text { effects recorded by } \\
\text { recipients between days } \\
1-7 \text { post -vaccination } \\
\text { Adverse events requiring } \\
\text { medical attention recorded } \\
\text { for one month post- } \\
\text { vaccination and medically } \\
\text { significant and serious } \\
\text { adverse events recorded } \\
\text { for } 6 \text { months post-vaccination }\end{array}$ & See Above & $\begin{array}{l}\text { Similar reactogenicity profile } \\
\text { between Men-C-ACYW-135- } \\
\text { CRM and Men-C-ACYW-135-D } \\
\text { with rates of local reactions } \\
\text { slightly higher with Men-C- } \\
\text { ACYW-135-CRM and systemic } \\
\text { reactions slightly higher with } \\
\text { Men-C-ACYW-135-D } \\
\text { No serious adverse events were } \\
\text { considered possibly or probably } \\
\text { related to the vaccine }\end{array}$ & Level 1 & Good \\
\hline
\end{tabular}




\begin{tabular}{|c|c|c|c|c|c|c|}
\hline Study & Vaccine & Study Design & Participants & Outcomes & $\begin{array}{l}\text { Level of } \\
\text { Evidence }\end{array}$ & Quality \\
\hline $\begin{array}{l}\text { Gill CJ } \\
\text { et al(39) }\end{array}$ & $\begin{array}{l}\text { Men-C-ACYW-135-CRM } \\
\text { without adjuvant } \\
\text { (Menveo }^{\text {TM}} \text { ) } \\
\text { in 19-65 year olds } \\
\text { Compared to } \\
\text { Men-C-ACYW-135-D } \\
\text { (Menactra }{ }^{\text {TM})} \\
\text { in 19-55 year olds } \\
\text { Compared to } \\
\text { unconjugated } \\
\text { quadrivalent } \\
\text { polysaccharide } \\
\text { (Men-P-ACYW-135 } \\
\text { - Menomune) } \\
\text { in 56-65 year olds }\end{array}$ & $\begin{array}{l}\text { See above } \\
\text { Solicited injection site } \\
\text { and systemic reactions for } \\
7 \text { days post-vaccination } \\
\text { Adverse events for } 6 \text { months } \\
\text { post-vaccination }\end{array}$ & See above & $\begin{array}{l}\text { Rates of solicited local } \\
\text { and systemic reactions similar } \\
\text { among vaccine groups }\end{array}$ & Level 1 & $\begin{array}{l}\text { Good } \\
\text { Poster } \\
\text { only so } \\
\text { difficult } \\
\text { to assess } \\
\text { full } \\
\text { method- } \\
\text { ology }\end{array}$ \\
\hline $\begin{array}{l}\text { Arguedas, } \\
\text { A et al. }{ }^{(41)}\end{array}$ & $\begin{array}{l}\text { Men-C-ACYW-135-CRM } \\
\text { (Menveo }{ }^{\mathrm{TM}} \text { ) given with } \\
\text { Tdap and HPV } \\
\text { Compared to } \\
\text { Men-C-ACYW-135-CRM } \\
\text { given one month } \\
\text { before or after Tdap } \\
\text { and HPV beginning } \\
\text { one month later }\end{array}$ & $\begin{array}{l}\text { See above } \\
\text { Solicited local and } \\
\text { systemic reactions were } \\
\text { recorded for } 7 \text { days } \\
\text { post-vaccination; other } \\
\text { adverse reactions were } \\
\text { recorded for one month } \\
\text { post-vaccination }\end{array}$ & See Above & $\begin{array}{l}\text { Rates of local reactions were } \\
\text { similar when Men-C-ACYW- } \\
\text { 135-CRM administered } \\
\text { concomitantly or separately } \\
\text { Slightly higher reports of } \\
\text { systemic reaction when } \\
\text { Men-C-ACYW-135-CRM } \\
\text { administered concomitantly } \\
\text { (58\%) than when given alone } \\
\text { (51\%) or after Tdap (43\%) } \\
\text { No serious adverse events } \\
\text { were considered possibly or } \\
\text { probably related to the vaccine }\end{array}$ & Level 1 & Good \\
\hline $\begin{array}{l}\text { Gasparini } \\
\text { et al }{ }^{(42)}\end{array}$ & $\begin{array}{l}\text { Men-C-ACYW-135-CRM } \\
\text { (Menveo }^{\text {TM}} \text { ) given } \\
\text { with Tdap } \\
\text { Compared to } \\
\text { Men-C-ACYW-135-CRM } \\
\text { given alone with a } \\
\text { placebo, and Tdap } \\
\text { given alone with } \\
\text { a placebo }\end{array}$ & $\begin{array}{l}\text { See above } \\
\text { Local and systemic } \\
\text { side effects and axillary } \\
\text { temperature recorded } \\
\text { by recipients or their } \\
\text { parents between days 1-7 } \\
\text { post-vaccination } \\
\text { Adverse events requiring } \\
\text { medical attention recorded } \\
\text { for one month post- } \\
\text { vaccination and medically } \\
\text { significant and serious } \\
\text { adverse events } \\
\text { recorded for } 6 \text { months } \\
\text { post-vaccination }\end{array}$ & See above & $\begin{array}{l}\text { No clinically significant vaccine } \\
\text { adverse events noted. } \\
\text { Local and systemic reactions } \\
\text { were generally reported more } \\
\text { frequently in the concomitant } \\
\text { group and in the Tdap alone } \\
\text { group, compared to the } \\
\text { Men-C-ACYW-135-CRM } \\
\text { alone group. }\end{array}$ & Level 1 & Good \\
\hline
\end{tabular}




\begin{tabular}{|c|c|c|c|c|c|c|}
\hline \multicolumn{7}{|c|}{ EVIDENCE OF SAFETY OF MEN-C-ACYW-135-D ADMINISTERED WITH TDAP AND HPV VACCINES } \\
\hline Study & Vaccine & Study Design & Participants & Outcomes & $\begin{array}{l}\text { Level of } \\
\text { Evidence }\end{array}$ & Quality \\
\hline $\begin{array}{l}\text { ReisingerKS, } \\
\text { et al.(.43) }\end{array}$ & $\begin{array}{l}\text { Men-C-ACYW-135-D } \\
\text { with human } \\
\text { papillomavirus vaccine } \\
\text { and Tdap administered } \\
\text { concomitantly } \\
\text { Compared to human } \\
\text { papillomavirus vaccine } \\
\text { given alone and } \\
\text { Men-C-ACYW-135-D } \\
\text { and Tdap given } \\
\text { together }\end{array}$ & $\begin{array}{l}\text { See above } \\
\text { On a report card, } \\
\text { reported temperature } \\
\text { and injection site } \\
\text { reactions for } 5 \text { days } \\
\text { after each vaccination } \\
\text { and systemic reactions } \\
\text { for } 14 \text { days after each } \\
\text { vaccination } \\
15 \text { days or more after } \\
\text { each vaccination only } \\
\text { deaths or serious } \\
\text { reactions felt by the } \\
\text { investigator to be } \\
\text { vaccine or study } \\
\text { related were reported }\end{array}$ & See above & $\begin{array}{l}\text { Higher local reactions in the } \\
\text { concomitant group, with more } \\
\text { injection site swelling in the HPV } \\
\text { arm compared to when HPV given } \\
\text { alone and more bruising and } \\
\text { pain in the Men-C-ACYW-135-D } \\
\text { and Tdap arm when given on } \\
\text { the same day as HPV compared } \\
\text { to when only Men-C-ACYW-135-D } \\
\text { and Tdap given on the same day. } \\
\text { No serious reactions in either group } \\
\text { following Men-C-ACYW-135-D } \\
\text { and Tdap }\end{array}$ & Level 1 & $\begin{array}{l}\text { Fair } \\
\text { - Comparison } \\
\text { involved } \\
\text { Men-C-ACYW- } \\
\text { 135-D and } \\
\text { Tdap given } \\
\text { together } \\
\text { instead of } \\
\text { each vaccine } \\
\text { alone }\end{array}$ \\
\hline
\end{tabular}


TABLE 9: Levels of Evidence Based on Research Design

\begin{tabular}{l|l}
\hline I & Evidence from randomized controlled trial(s). \\
\hline II-1 & Evidence from controlled trial(s) without randomization. \\
\hline II-2 & $\begin{array}{l}\text { Evidence from cohort or case-control analytic studies, preferably from more than one centre or research group using clinical } \\
\text { outcome measures of vaccine efficacy. }\end{array}$ \\
\hline II-3 & $\begin{array}{l}\text { Evidence obtained from multiple time series with or without the intervention. Dramatic results in uncontrolled experiments (such as } \\
\text { the results of the introduction of penicillin treatment in the 1940s) could also be regarded as this type of evidence. }\end{array}$ \\
\hline III & $\begin{array}{l}\text { Opinions of respected authorities, based on clinical experience, descriptive studies and case reports, or reports of expert } \\
\text { committees. }\end{array}$ \\
\hline
\end{tabular}

TABLE 10: Quality (internal validity) Rating of Evidence

\begin{tabular}{l|l}
\hline Good & A study (including meta-analyses or systematic reviews) that meets all design- specific criteria* well. \\
\hline Fair & $\begin{array}{l}\text { A study (including meta-analyses or systematic reviews) that does not meet (or it is not clear that it meets) at least one } \\
\text { design-specific criterion* but has no known "fatal flaw". }\end{array}$ \\
\hline Poor & $\begin{array}{l}\text { A study (including meta-analyses or systematic reviews) that has at least one design-specific* "fatal flaw", or an } \\
\text { accumulation of lesser flaws to the extent that the results of the study are not deemed able to inform recommendations. }\end{array}$ \\
\hline
\end{tabular}

\section{TABLE 11: NACI Recommendation for Immunization - Grades}

\begin{tabular}{l|l}
\hline A & $\mathrm{NACl}$ concludes that there is good evidence to recommend immunization. \\
\hline B & $\mathrm{NACl}$ concludes that there is fair evidence to recommend immunization. \\
\hline C & $\begin{array}{l}\mathrm{NACl} \text { concludes that the existing evidence is conflicting and does not allow making a recommendation } \\
\text { for or against immunization, however other factors may influence decision-making. }\end{array}$ \\
\hline D & $\mathrm{NACl}$ concludes that there is fair evidence to recommend against immunization. \\
\hline E & $\mathrm{NACl}$ concludes that there is good evidence to recommend against immunization. \\
\hline I & $\begin{array}{l}\mathrm{NACl} \text { concludes that there is insufficient evidence (in either quantity and/or quality) to make a recommendation, } \\
\text { however other factors may influence decision-making. }\end{array}$ \\
\hline
\end{tabular}

TABLE 12: Possible schedules for vaccinating children less than 2 years of age who are at high-risk for meningococcal disease due to medical conditions specified in this statement, travel or who are close contacts of invasive meningococcal disease caused by serogroups A, W135 or Y or to control outbreaks caused by these serogroups.

\begin{tabular}{|c|c|}
\hline Age & Possible Schedules \\
\hline $\begin{array}{l}2 \text { months to less than } \\
12 \text { months of age }\end{array}$ & $\begin{array}{l}\text { Men-C-ACYW-135-CRM (Menveo }{ }^{\mathrm{TM}} \text { ) } 2 \text { or } 3 \text { doses given } 8 \text { weeks apart* with another dose } \\
\text { between } 12 \text { and } 23 \text { months and at least } 8 \text { weeks* from the previous dose }\end{array}$ \\
\hline $\begin{array}{l}12 \text { to } 23 \text { months } \\
\text { of age }\end{array}$ & Men-C-ACYW-135-CRM (Menveo ${ }^{\mathrm{TM}}$ ) 2 doses at least 8 weeks apart* \\
\hline \multicolumn{2}{|c|}{ * Minimum interval of 4 weeks if rapid protection is required } \\
\hline \multicolumn{2}{|c|}{$\begin{array}{l}\text { Note: Men-C-ACYW-135-CRM (Menveo }{ }^{\mathrm{TM}} \text { ) is not yet authorized for children less than } 2 \text { years of age, therefore, there are no authorized schedules } \\
\text { for these children. The above schedules are based on schedules used in published clinical trials and NACl's previous recommendation that a dose } \\
\text { of meningococcal conjugate vaccine be given in the second year of life ( } 12 \text { to } 23 \text { months) for children vaccinated at less than } 1 \text { year of age. }\end{array}$} \\
\hline 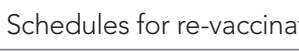 & tion are outlined in this statement. \\
\hline
\end{tabular}




\section{References}

(1) National Advisory Committee on Immunization (NACl). An Advisory Committee Statement (ACS). Statement on recommended use of meningococcal vaccines. Canada Communicable Disease Report. 2001;27:2-36.

(2) National Advisory Committee on Immunization (NACI). Supplementary statement on conjugate meningococcal vaccines. Canada Communicable Disease Report. 2003;29:10-1.

(3) National Advisory Committee on Immunization (NACI). Statement on conjugate meningococcal vaccine for serogroups A, C, Y and W135. An Advisory Committee Statement (ACS). Canada Communicable Disease Report. 2007;33 (ACS-3):1-23.

(4) National Advisory Committee on Immunization (NACI). Meningococcal $\mathrm{C}$ conjugate vaccination recommendations for infants. An Advisory Committee Statement. Canada Communicable Disease Report. 2007;33 (ACS-11):1-12.

(5) National Advisory Committee on Immunization (NACI). An update on the invasive meningococcal disease and meningococcal vaccine conjugate recommendations. An Advisory Committee Statement (ACS). Canada Communicable Disease Report. 2009;36 (ACS-3):1-40.

(6) Bettinger JA, Scheifele DW, Le SN, et al. The impact of childhood meningococcal serogroup $\mathrm{C}$ conjugate vaccine programs in Canada. Pediatr Infect Dis J. 2009;28(3):220-4.

(7) Kinlin LM, Jamieson F, Brown EM, et al. Rapid identification of herd effects with the introduction of serogroup $C$ meningococcal conjugate vaccine in Ontario, Canada, 2000-2006. Vaccine. 2009;27(11):1735-40.

(8) Siu T, Tang W, Dawar $M$, et al. Impact of routine immunization using meningococcal $\mathrm{C}$ conjugate vaccine on invasive meningococcal disease in British Columbia. Canadian Journal of Public Health. 2008(5):380-2.

(9) Public Health Agency of Canada. National enhanced invasive meningococcal surveillance. 2009.

(10) Public Health Agency of Canada. Publicly funded immunization programs in Canada - routine schedule for infants and children. www.phac-aspc.gc.ca/im/ptimprogprogimpt/table-1-eng.php Accessed on June 23, 2011.
(11) MacNeil JR, Cohn AC, Zell ER et al. Early estimate of effectiveness of quadrivalent meningococcal conjugate vaccine. Pediatric Infectious Disease Journal. 2011;30 (6): 451-55.

(12) Cohen A. Optimizing the adolescent meningococcal vaccination program. Presentation to the Advisory Committee on Immunization Practices October 27, 2010.

(13) Centre for Disease Control and Prevention. Updated recommendations for use of meningococcal vaccines. Advisory Committee on Immunization Practices (ACIP), 2010, January 28, 2011;60 (3):72-6.

(14) Snape MD, Pollard AJ. Meningococcal polysaccharideprotein conjugate vaccines. Lancet Infect Dis. 2005;5(1): 21-30.

(15) Goldschneider I, Gotschilch EC, Artenstein MS. Human immunity to the meningococcus. The Journal of Experimental Medicine. 1969;129(6):1307-26.

(16) Borrow R, Balmer P, Miller E. Meningococcalcoccal surrogates of protection serum bactericidal antibody activity. Vaccine. 2005;23(17-18):2222-7.

(17) Gheesling LL, Carlone GM, Pais LB, et al. Multicenter comparison of Neisseria meningitidis serogroup $C$ anti-capsular polysaccharide antibody levels measured by a standardized enzyme-linked immunosorbent assay. J Clin Microbiol. 1994;32(6):1475-82.

(18) Richmond P, Goldblatt D, Fusco PC, et al. Safety and immunogenicity of a new Neisseria meningitidis serogroup C-tetanus toxoid conjugate vaccine in healthy adults. Vaccine. 1999;18(7-8):641-6.

(19) Borrow R, Goldblatt D, Andrews N, et al. Antibody persistence and immunological memory at age 4 years after meningococcal group $\mathrm{C}$ conjugate vaccination in children in the United Kingdom. J Infect Dis. 2002;186(9): 1353-7.

(20) Borrow R, Goldblatt D, Finn A, et al. Immunogenicity of, and Immunologic Memory to, a Reduced Primary Schedule of Meningococcal C-Tetanus Toxoid Conjugate Vaccine in Infants in the United Kingdom. Infect Immun. 2003;71(10):5549-55. 
(21) MacLennan JM, Shackley F, Heath PT, et al. Safety, immunogenicity, and induction of immunologic memory by a serogroup $\mathrm{C}$ meningococcal conjugate vaccine in infants: A randomized controlled trial. JAMA. 2000;283(21): 2795-801.

(22) Richmond P, Borrow R, Miller E, et al. Meningococcal serogroup $\mathrm{C}$ conjugate vaccine is immunogenic in infancy and primes for memory. J Infect Dis. 1999;179(6):1569-72.

(23) Richmond P, Borrow R, Goldblatt D, et al. Ability of 3 different meningococcal $C$ conjugate vaccines to induce immunologic memory after a single dose in UK toddlers. J Infect Dis. 2001;183(1):160-3.

(24) Meningococcal infection-meningococcal meningitis. In: Heymann, DL editor Control of Communicable Disease Manual. 18 ${ }^{\text {th }}$ ed Washington: American Public Health Association. 2004:359-66.

(25) Snape MD, Kelly DF, Green B, et al. Lack of serum bactericidal activity in preschool children two years after a single dose of serogroup $\mathrm{C}$ meningococcal polysaccharide-protein conjugate vaccine. Pediatr Infect Dis J. 2005;24(2):128-31.

(26) McVernon J, Maclennan J, Buttery J, et al. Safety and immunogenicity of meningococcus serogroup $\mathrm{C}$ conjugate vaccine administered as a primary or booster vaccination to healthy four-year-old children. Pediatr Infect Dis J. 2002;21(8):747-53.

(27) Black S, Klein NP, Shah J, et al. Immunogenicity and tolerability of a quadrivalent meningococcal glycoconjugate vaccine in children 2-10 years of age. Vaccine. 2010;28(3): 657-63.

(28) Snape MD, Perrett KP, Ford KJ, et al. Immunogenicity of a tetravalent meningococcal glycoconjugate vaccine in infants: a randomized controlled trial. JAMA. 2008; 299(2):173-84.

(29) Campbell H, Andrews N, Borrow R, et al. Updated post licensure surveillance of the meningococcal $\mathrm{C}$ conjugate vaccine in England and Wales: effectiveness, validation of serological correlates of protection, and modeling predictions of the duration of herd immunity. Clin Vaccine Immunol. 2010;17(5):840-7.

(30) Novartis Vaccines Inc. Menveo ${ }^{\text {TM }}$ Clinical Data Update. Presentation at the National Advisory Committee on Immunization meeting, Ottawa, Ontario. February 2, 2010.
(31) Perrett KP, Snape MD, Ford KJ, et al. Immunogenicity and immune memory of a nonadjuvanted quadrivalent meningococcal glycoconjugate vaccine in infants. Pediatr Infect Dis J. 2009;28(3):186-93.

(32) Halperin SA, Diaz-Mitoma F, Dull P, et al. Safety and immunogenicity of an investigational quadrivalent meningococcal conjugate vaccine after one or two doses given to infants and toddlers. Eur J Clin Microbiol Infect Dis. 2010;29(3):259-67.

(33) Vesikari T, Ceddia F, Karvonen A, et al. Immune response and immunologic memory induced by a novel meningococcal ACWY-CRM conjugate vaccine (MenACWY) in toddlers. in the $23^{\text {rd }}$ annual meeting of the European Society of Paediatric Infectious Diseases (ESPID). 2005.

(34) Halperin,SA, Gupta, A, Jeanfreau, R, et al. Comparison of the safety and immunogenicity of an investigational and a licensed quadrivalent meningococcal conjugate vaccine in children 2-10 years of age. Vaccine. 2010; 28(50):7865-72.

(35) Jackson LA, Jacobson RM, Reisinger K, et al. A randomized trial to determine the tolerability and immunogenicity of a quadrivalent meningococcal glycoconjugate vaccine in healthy adolescents. Pediatr Infect Dis J. 2009;28:86-91.

(36) Jackson LA, Baxter R, Reisinger K, et al. Phase III comparison of an investigational quadrivalent meningococcal conjugate vaccine with the licensed meningococcal ACWY conjugate vaccine in adolescents. Clin Infect Dis. 2009; 49(1):e1-e10.

(37) Gill C, Baxter R, Anemona A, et al. Persistence of immune responses after a single dose of Novartis meningococcal serogroup A, C, W-135 and Y CRM-197 conjugate vaccine (Menveo ${ }^{\mathrm{TM}}$ ) or Menactra ${ }^{\mathrm{TM}}$ among healthy adolescents. Human Vaccines. 2010;6(11):1-7.

(38) Reisinger K, Baxter R, Block SL, et al. Quadrivalent meningococcal vaccination of adults: Phase III comparison of an investigational conjugate vaccine, MenACWY-CRM, with the licensed vaccine, Menactra ${ }^{\mathrm{TM}}$. Clin Vaccine Immunol. 2009;16(12):1810-5.

(39) Gill CJ., Karsten A, Bedell L et al. Safety and immunogenicity in clinical trials of Menveo ${ }^{\text {TM }}$ Quadrivalent meningococcal glyconjugate vaccine, in adults up to 65 years old. Presented at the $28^{\text {th }}$ Annual Meeting of the European Society for Paediatric Infectious Disease (ESPID). May 4-8, 2010, Nice, France. 
(40) Center for Disease Control and Prevention. Updated recommendations from the advisory committee on immunization practices (ACIP) for revaccination of persons at prolonged increased risk of meningococcal disease. MMWR. 2009;58(37):1042-3.

(41) Arguedas A, Soley C, Loaiza C, et al. Safety and immunogenicity of one dose of MenACWY-CRM, an investigational quadrivalent meningococcal glycoconjugate vaccine, when administered to adolescents consomitantly or sequentially with tdap and HPV vaccines. Vaccine. 2010;28(18):3171-9.

(42) Gasparini R, Conversano M, Bona G, et al. Randomized Trial on the Safety, Tolerability, and Immunogenicity of MenACWY-CRM, an Investigational Quadrivalent Meningococcal Glycoconjugate Vaccine, Administered Concomitantly with a Combined Tetanus, Reduced Diphtheria, and Acellular Pertussis Vaccine in Adolescents and Young Adults. Clin Vaccine Immunol. 2010;17(4):537-44.

(43) Reisinger K, Block SL, Collins-Ogle M, et al. Safety, tolerability, and immunogenicity of Gardasil given concomitantly with Menactra ${ }^{\mathrm{TM}}$ and Adacel ${ }^{\mathrm{TM}}$. Pediatrics. 2010;125(6):1142-51.

(44) Diez-Domingo J, Bernaola E, Gimenez-Sanchez F, et al. Safety and immunogenicity of 13-valent pneumococcal conjugate vaccine in healthy infants receiving routine vaccinations in Spain. Presented at the $27^{\text {th }}$ Annual Meeting of the European Society for Paediatric Infectious Disease (ESPID), June 9-13, 2009, Brussels, Belgium.

(45) Dagan R, Poolman J, Siegrist CA. Glycoconjugate vaccines and immune interference: A review. Vaccine. 2010;28(34):5513-23.
(46) Velentgas P. for the Meningococcal Vaccine Study Investigator Group. Meningococcal vaccine study, final study results. Presentation to the US Advisory Committee on Immunization Practices, June 23, 2010, Atlanta, Georgia, United States of America.

(47) Weintraub E, Menactra ${ }^{\mathrm{TM}}$ and GBS. Summary of VAERS and VSD rapid cycle analysis data. presentation to the US Advisory Committee on Immunization Practices. June 23, 2010, Atlanta, Georgia, United States of America.

(48) El Bashir H, Heath PT, Papa T, et al. Antibody responses to meningococcal (groups A, C, Y and W135) polysaccharide diphtheria toxoid conjugate vaccine in children who previously received meningococcal $\mathrm{C}$ conjugate vaccine. Vaccine. 2006;24(14):2544-9.

(49) Rennels M, King J,Jr, Ryall R, et al. Dosage escalation, safety and immunogenicity study of four dosages of a tetravalent meninogococcal polysaccharide diphtheria toxoid conjugate vaccine in infants. Pediatr Infect Dis J. 2004;23(5):429-35.

(50) Public Health Agency of Canada. Guidelines for the prevention and control of meningococcal disease. CCDR. 2005;31(S1):1-26.

(51) Gill CJ, Bedell L, McCarthy M, et al. Tolerability and safety of Menveo ${ }^{\circledR}$ quadrivalent meningococcal glycoconjugate vaccine against serogroups $A, C, W-135$ and $Y$ in children aged 2-10 years. Presented at the $28^{\text {th }}$ Annual Meeting of the European Society for Paediatric Infectious Disease (ESPID), May 4-8, 2008, Nice, France.

(52) Harris RP, Helfand M, Woolf SH, et al. Current methods of the US Preventive Services Task Force: A review of the process. Am J Prev Med. 2001;20(3 Suppl):21-35. 